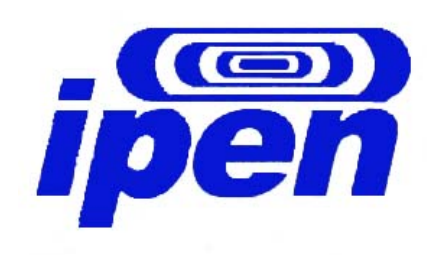

INSTITUTO DE PESQUISAS ENERg ÉtICAS E NucleARES

Autarquia Associada à Universidade de São Paulo

\title{
CARACTERIZAÇÃo E CINÉtICA de RECRISTALIZAÇÃo dA LIGA DE ALUMíNIO 6063 APÓS TRATAMENTOS TERMOMECÂNICOS
}

\section{IARA MARIA ESPÓSITO}

Dissertação apresentada como parte dos requisitos para obtenção do Grau de Mestre em Ciências na Área de Tecnologia Nuclear - Materia is.

O rienta dor: Dr. Waldemar Alfredo Monteiro 
SÃO PAULO

2006 
Aosmens pais, Aos meus irmãos, Ao meu marido E a todos que direta ow indiretamente, participaram da reatizacaio deste trabalho 
Ao mewamigo

Que sempre me auxiliou... Obrigada! 


\title{
CARACTERIZAÇÃO E CINÉTICA DE RECRISTALIZAÇÃO DA LIGA DE ALUMÍNIO 6063 APÓS TRATAMENTOS TERMOMECÂNICOS
}

\section{lara Maria Espósito}

\begin{abstract}
RESUMO
A liga de alumínio 6063 possui um grande interesse industrial, apresentando caracteństicas que justificam o seu uso mais freqüente quando comparadas às demais ligas de alumínio: a capacidade de endurecimento por precipitação (pois são termicamente tratáveis) aliada à facilidade de serem extrudadas. Estas ligas apresentam elevada ductilidade, que permite o seu uso em operações que acarretam elevados graus de deformação, como a extrusão. Por esse motivo, as ligas Al-Mg-Si apresentam a maiorparte do volume de ligas extrudadas.

Tendo em vista a freqüente utilização da liga de alumínio 6063, este trabalho estuda a caracterização e a recristalização da liga a pós a deformação plástica em diferentes graus de redução em área $20 \%, 50 \%$, $70 \%$ e $90 \%$, com tratamentos térmicos de $396^{\circ} \mathrm{C}$, $462^{\circ} \mathrm{C}$ e $528^{\circ} \mathrm{C}$ e com tempos de recozimento em 1minuto, 10 minutos e 100 minutos Tratamentos Temomecânicos.
\end{abstract}

Observou-se como resultados de uma forma geral, que os tratamentos com 1minuto nas amostras de Al6063 houve pouca ou 
nenhuma alteração e ao aumentamos o tempo de recozimento para 10 minutos e depois para 100 minutos os processos de recuperação/recristalização se tomam evidentes e o crescimento de ta mbém é observável para os tempos de tra tamento em 100 minutos. 
Kinetic Characterization And Of Recrystallization Of The Aluminum Alloy 6063 After S Work WARdening TREATMENT

\author{
lara Maria Espósito
}

\begin{abstract}
The aluminum 6063 alloy possesses a great industrial interest, presenting characteristics that justify its frequent use, when compared to the other aluminum alloys: the precipitation hardening and high cold work capacity. These alloys present high ductility, that allows their use in operations with high deformation degrees, as the cold work.

The objective of this work is to show comparative a nalysis of the hardness Vickers of the commercial aluminum 6063 alloy, after cold work with different area reduction degree and themal treatment.

Considening the frequent utilization a luminium 6063 alloy, this work studies the caracterization and recristalization of this alloy, after the plastc deformation in different area reduction degrees, themal treatment and convenient tratment times - Termomechanic Tratments.
\end{abstract}




\section{SUMÁRIO}

1. INTRODUÇÃO

2. OBj EIVO

REVISÃO DA LTIERATURA

3. - O Alumínio ................................................................................................... 11

3.1. - Liga de Alumínio - Série 6XXX - Al-Mg-Si ................................................. 13

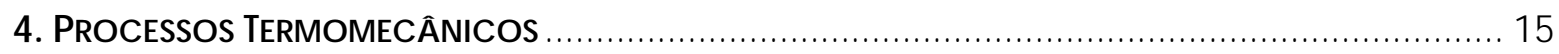

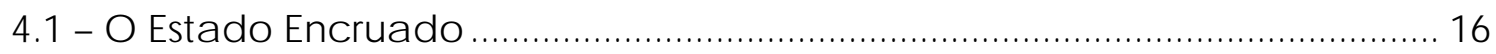

4.2 - Mic roestrutura e Deforma ção Plástic a ............................................................ 17

4.2.1 - Deformação Heterogênea na Mic roestrutura ..................................... 20

4.3 - O Tratamento Térmico o.............................................................................. 20

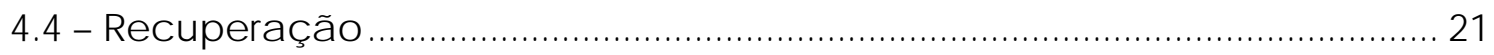

OS ESTÁGIOS DA RECUPERAÇÃo

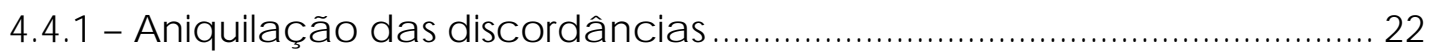

4.4.2 - Configurações estáveis de disc ordâncias ........................................... 22

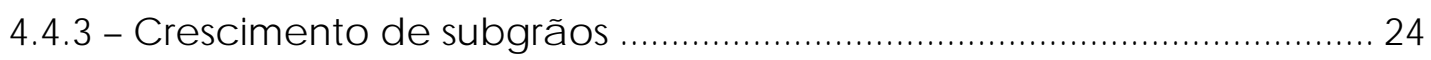

4.5 - Rec rista liza ção

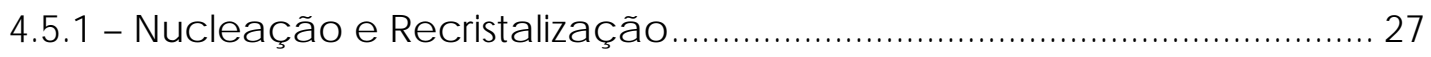

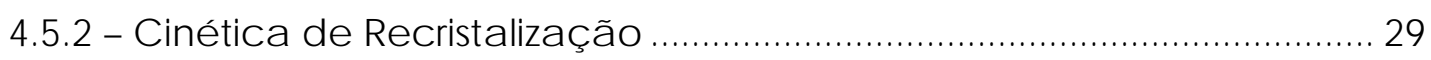

4.5.3 - Recrista liza ção de ligas na presença de segundas fases.................... 29

4.5.4 - Recrista liza ção Sec undária e Cresc imento de G rão ............................. 30

\section{TEECIICAS UTIUZADAS NO ESTUDO DA RECRISTAUZAÇÃO}

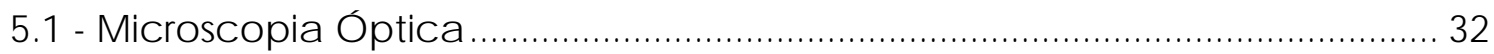

5.2 - Mic roscopia Eletrônic a ........................................................................... 33

5.2.1 - Mic rosc opia Eletrônica de Transmissã o ………...................................... 34

5.3 - Ensaio de Dureza ...................................................................................... 35

\section{6. - Procedimento EXPerimental/ Metodologia}

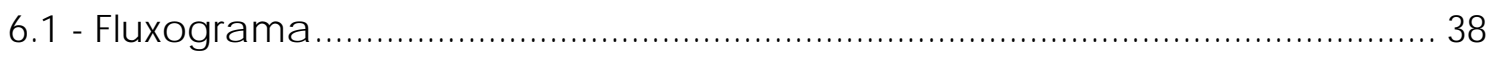

6.2 - Análise químic a das a mostras da liga de alumínio 6063 ............................... 39

6.3 - Preparação - Deformação das a mostras por laminação a frio .................. 39

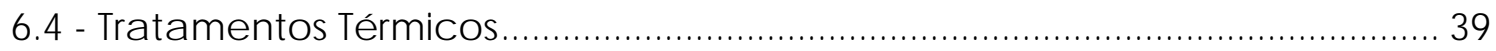

6.5 - Preparação de Amostras para Microscopia Óptica .................................... 40

6.6 - Ensa io Microdureza Vickers a pós trata mento temomec ânico ................... 41

6.7 - Medida de Tamanho Médio de Grão ............................................................. 41

6.8 - Preparação de Amostras para Microscopia Eletrônica de Transmissão ..... 42 


\section{7. - ResultAdOs E Discussões}

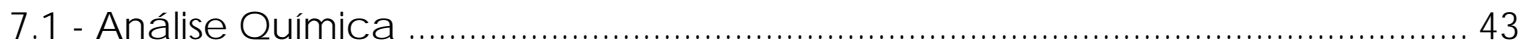

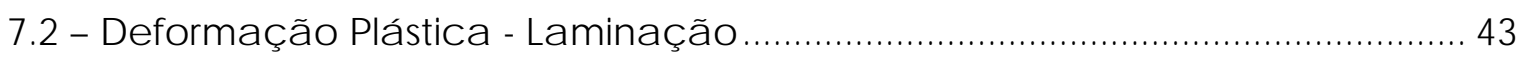

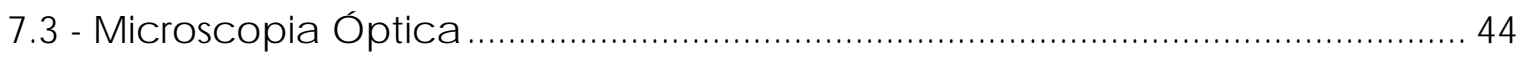

7.3.1 - Liga de alumínio 6063 - 20\% de redução em área ................................... 45

7.3.2 - Liga de alumínio 6063 - 50\% de redução em área ..................................... 49

7.3.3 - Liga de alumínio 6063 - 70\% de redução em área...................................... 53

7.3.4 - Liga de alumínio 6063 - 90\% de redução em área .................................... 57

7.4 - Mic rosc opia eletrônic a de Transmissão ……………………………………....... 61

7.5 - Tamanho Médio de Grão ............................................................................. 64

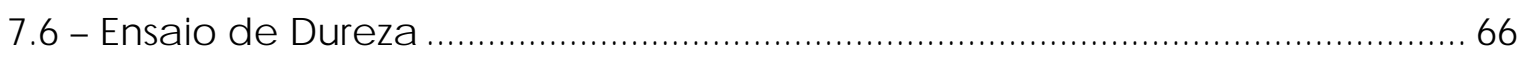

8. - CONCLSÕES

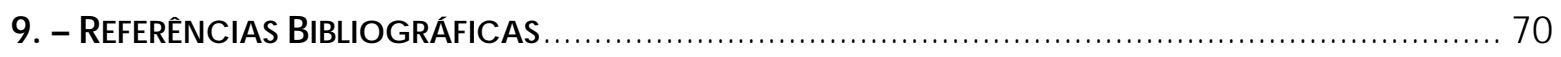




\section{1. - INTRODUÇÃO}

$\mathrm{Na}$ última década, materiais leves têm sido amplamente estudados e utilizados em componentes de peças e estampo nas indústrias: a utomobilística, naval, a eroespacial, a lém de uma infinida de de a plic ações arquitetônica s como, por exemplo, portas, ja nelas, esqua drias, entre outras. Sua aplicação possibilita: reduzir a massa, aumentar a capacidade de carga e, quando há possibilidade, melhorar as propriedades mecânicas.

Os principais critérios para seleção desses materiais quanto às aplicações estruturais são: resistência mecânica específica (relação resistência-peso) e a rigidez espec ífica, que difere em muito entre os vários materia is de liga leve [1].

Dentre esses materiais, as ligas de alumínio têm destaque especial, devido não somente à leveza do material, mas também a certas propriedades mecânicase a sua recic labilidade [1,2].

Princ ipa is a plic ações do a lumínio:

- Indústria de transporte: automóveis, caminhões, ônibus, autopeças de vagões, trailers, radiadores, rodas, carroceniase implementosagrícolas.

- Indústria de eletricidade: cabos condutores, barramentos, eletrodutos, capacitores, lâmpadase luminárias.

- Máquinas e equipamentos: Peças fundidas para máquinas industriais de mineração e de agricultura, componentes, ta is como, chapas, tubos, perfis, chapas litográficas e peças usinadas.

- Embalagens: para medicamentos, bebidas e produtos a limentícios como, por exemplo, bisnagas, tubos ń́gidos, 
tampas, cápsulas, latas, bandejas, recipientes témicos e papel a lumínio.

- Bens de consumo: eletrodomésticos, eletroeletrônicos, utensilios domésticos, máquinas de escritónio, móveis, barcos, brinquedos e artigos esportivos.

- Construção civil: estruturas, portas, fachadas, box de banheiro, forros, divisórias, persianas, telhas, toldos, calhas, revestimentos intemos, revestimentos extemos, revestimentos de fachadase silos.

- Diversos: Tubos para imigação, explosivos, combustível para foguetes, esculturas, tintas metálicas, desoxidante na indústria sidenúrgica e redutorna fabricação de ferro-ligas, etc.

O alumínio apresenta estrutura cúbica de face centrada (c.f.c.), parâmetro de rede $a \approx 0,4041 \mathrm{~nm}$, baixa densidade, altos valores de condutivida de térmic a e elétric $a$, ductibilidade e resistência à corrosão.

As impureza s comuns encontra das no alumínio são: $\mathrm{Fe}, \mathrm{Si}, \mathrm{Ti}, \mathrm{Cu}$ e Zn e estes, em geral, pioram as propriedades físic as previamente citadas. Contudo, a inclusão de certas concentrações de impurezas e tratamentos mecânicos (deformação plástica, por exemplo) pode melhorar a resistência mecânica e a dureza do alumínio e de suas ligas [1,3].

Dentre as ligas de alumínio comercia is destacam-se as da série 6XXX, devido a sua facilidade de ser trabalhada, quando comparada, com as dema is ligas termic a mente tratáveis (Al-Zn-Mg e $\mathrm{Al}-\mathrm{Cu}$ ), sendo as ligas Al-Mg-Si as que a presentam maior soldabilidade e maior resistência à corrosão comparando-se as anteriores.

Da série 6XXX, a que estudaremos é a liga 6063 que apresenta duas caracteństicas que justificam o uso mais freqüente quando comparada às demais liga de alumínio: a capacidade de endurecimento por precipitação (é temicamente tratável) e têm, também, uma elevada ductilidade, permite o seu uso em operações que acarretem elevados graus de deformação, como, por exemplo, a extrusão. ${ }^{[4]}$ 
Este trabalho estuda a recuperação e recristalização da liga de a lumínio comercial 6063(Al-Mg-Si).

Seu objetivo é a análise dos aspectos mic roestrutura is resultantes de processamentos mecânicos a frio (deformação plástica) e tratamentos térmicos posteriores que resultem na recuperação e recristalização da microestrutura da liga de alumínio comercial 6063.

O processo de recuperação e recristalização pode ser acompanhado por diversas técnicas analíticas, como por exemplo, a microscopia óptica, microscopia eletrônica de transmissão, testes de microdureza, entre outras, evidenciando a recristalização da liga de a lumínio comercial 6063 e as ca racteństic as mic roestrutura is obtidas. 


\section{REVISÃO DA LTERATURA}

\section{3- O ALUMíNIO}

O alumínio é o metal mais abundante na crosta terrestre do nosso planeta. E, embora existindo em grandes quantida des, o alumínio só podia ser encontra do em seu esta do metálico em pequenas quantidades no início do século XIX, permanecendo como curiosidade até 1886, quando estudos independentes de Heroult, na França e de Hall nos Estados Unidos, resultaram um método de extração eletrolítica, que permitiu que a produção de alumínio pudesse se tomar viável economic amente.

Desde então, as excelentes propriedades de engenharia apresentadas pelo alumínio e suas ligas, têm sido exploradas comercialmente, e a emergência do a lumínio como metal comercial tem sido função da disponibilidade de grandes quantidades de energia elétrica. ${ }^{[5]}$

O alumínio é obtido a partir do minério bauxita, que é constituído, usualmente, por 40 a $60 \%$ de alumina hidratada e impurezas como óxidos de ferro, ślica e titânia.

A bauxita é formada pelo desgaste do tempo de rochas que contém alumínio, tais como granito e basalto, quando expostas a condições de clima tropical. Sabe-se que as maiores reservas do minério são encontradas na Austrália, no Brasil e na Guiana.

A produção de alumínio a partir da bauxita envolve dois processos distintos, isto é, numa primeira etapa é produzida a lumina, e na seguinte o alumínio é extraído eletrolitica mente desta a lumina. 
Nomalmente, a produção de uma tonelada de alumínio requer quatro toneladas de bauxita, que produz 1,9 toneladas de alumina, a partir da qual são produzidos $1.000 \mathrm{~kg}$ de alumínio. Outros materia is são ta mbém consumidos em quantidades signific ativas: 0,3 tonelada de óleo combustível e 0,45 tonelada de carbono. O fator ma is crítico no processo, no entanto, é o consumo de energia elétrica que está na faixa de 14.000 kWh portonelada de alumínio produzido.[5]

O alumínio é um metal que na sua forma pura apresenta baixa densidade, estrutura cúbica de face centrada, c.f.c., boa resistência à corrosão, condutividade témica e elétrica, soldabilidade e conformabilidade, resistência mecânica significativa, entre outras propriedades (Tabela 1)[6]. Na forma de suas ligas, essas propriedades se mantêm ou são alteradas em função das necessidades de suas aplic ações.

Tabela 1. Algumas propriedades do Alumínio.

\begin{tabular}{l|l|l}
\hline \multicolumn{1}{c|}{ Propriedades Físicas } & Alumínio & \multicolumn{1}{c}{ Unidades } \\
\hline Densidade & 2,71 & $\mathrm{~g} / \mathrm{cm}^{3}\left(20^{\circ} \mathrm{C}\right)$ \\
Temperatura de Fusão & 660 & ${ }^{\circ} \mathrm{C}$ \\
Módulo de Elasticidade & 69000 & $\mathrm{MPa}$ \\
Coefic iente de Expansão Linear & $23 \times 10^{-6}$ & $\mathrm{~L}^{\circ} \mathrm{C}$ \\
Condutibilidade Témica & 0,56 & $\mathrm{Cal} / \mathrm{cm}{ }^{\circ} \mathrm{C}\left(25^{\circ} \mathrm{C}\right)$ \\
Condutibilidade Elétrica & 62 & (IACS)\% \\
\hline
\end{tabular}

As nomenclaturas das ligas de alumínio produzidas comercialmente indicam sua pureza, modificações da liga e os principa is elementos de liga que as compõe, assim, o primeiro dígito indica o grupo de liga, e os dois últimos identificam a liga de alumínio ou indicam a sua pureza. O segundo dígito indica as modificações da liga original ou os limites da pureza. Assim, temos a seguinte nomenclatura para as ligas de a lumínio (Tabela 2)[7].

Tabela 2. Nomenclatura para as ligas de alumínio. 


\begin{tabular}{cl}
\hline $\begin{array}{c}\text { Tipo da liga } \\
\text { Série de } 4 \text { dígitos }\end{array}$ & Principal elemento de liga \\
\hline IXXX & pureza $>99,00 \%$ de Al \\
\hline $2 X X X$ & Cobre \\
\hline $3 X X X$ & Manganês \\
\hline $4 X X X$ & Silício \\
\hline $5 X X X$ & Magnésio \\
\hline $6 X X X$ & Magnésio e Silíc io \\
\hline $7 X X X$ & Znco \\
\hline $8 X X X$ & Outroselementos \\
\hline $9 X X X$ & Não Usado \\
\hline
\end{tabular}

Fonte: IADS - Intemational Alloy Designation System

(Sistema Intemacional de Designação de Ligas)

\section{1. - LIGA de AlumínIO - SÉRIE 6XXX - AL-MG-SI[8]}

Foi introduzida em 1921 a liga Al 6051, com 1\%Si e 0,5\%Mg; foi um dos primeiros casos de sucesso de ligas envelhecíveis sem $\mathrm{Cu}$. Outras versões ma is a perfeiçoadas resultaram, em 1928, na liga Al 6151 de maior resistência mecânica e ductibilidade. Com 1\%Mg e 0,6\%Si, a liga Al 6061, sendo utilizada para fins estruturais, sua composição apresenta a exata proporção de $\mathrm{Mg}$ e Si para a formação de $\mathrm{Mg}_{2} \mathrm{Si}$, e contém, ainda, $0,25 \%$ C u e de 0,05 a $0,35 \%$ r.

O ano de 1944 marcou a introdução da liga de alumínio 6063, muito usada em extrudados. Com $0,67 \% \mathrm{Mg}$ e $0,4 \% \mathrm{Si}$, em sua composição básica, embora seja possível se encontrar variantes especia is.

Outras ligas contendo teores de liga maiores foram desenvolvidas seqüencialmente: 6066 em 1954, 6070 em 1962 e 6013 em1983.

As ligas 6009 e 6010 foram introduzidas em 1976, suprindo a necessidade de uma liga conformável numa condição específica de têmpera (nomenclatura intemacional para condição de tratamento termomecânico específico), mas que envelhecesse durante a secagem da pintura de automóveis ${ }^{[9]}$. 
$\mathrm{Na}$ Tabela 3, temos a composição química, padrão, da amostra da liga de alumínio 6063.

Tábela 3 - Composição química padrão da liga de alumínio 6063 [10]

\begin{tabular}{cccccccccc}
\hline Eemento & $\mathbf{S}$ & $\mathbf{M g}$ & $\mathbf{F e}$ & $\mathbf{C r}$ & $\mathbf{C u}$ & $\mathbf{Z n}$ & $\mathbf{M n}$ & $\mathbf{\pi}$ & Outros \\
\hline$\%$ & 0,20 & 0,45 & 0,35 & 0,10 & 0,10 & 0,10 & 0,10 & 0,10 & 0,15 \\
\hline$\%($ Máximo) & 0,60 & 0,90 & $\max$ & $\max$ & $\max$ & $\max$ & $\max$ & $\max$ & $\max$ \\
\hline
\end{tabular}

Fonte: The Aluminum Association.

Nas ligas de alumínio da série 6XXX o magnésio e o silício combinam-se para formar o composto intermetálico $\mathrm{Mg}_{2} \mathrm{Si}$ que, antes de atingir o equilíbrio no superenvelhecimento, é o responsável pelo endurecimento dessas ligas. A solubilidade do precipitado $\mathrm{Mg}_{2} \mathrm{Si}$ na matriz rica em alumínio aumenta com a elevação da temperatura. O trata mento de solubiliza ção e envelhec imento artific ial controlado permite esta precipitação, a partir de uma solução sólida supersaturada. Isso favorece a formação de precipitados finos e uniformemente distribuídos, que acarretam um aumento na dureza do material [11].

Os aumentos da dureza com o tempo e a temperatura de envelhecimento estão relacionados com o crescimento dos precipitados $\mathrm{Mg}_{2} \mathrm{Si}$. A queda de dureza, que ocorre para tratamentos térmicos a altas temperaturas e/ou longos tempos de envelhecimento, está relacionada, com o crescimento excessivo destes precipitados, favorecendo o movimento das discordâncias quando de uma solicitação mecânica, o que possibilita o amolecimento da liga, e que caracteriza o superenvelhec imento.

A Tabela 4 é apresentado em ordem de percentual de concentração, o principal elemento da liga de alumínio 6063 e impurezas, e seus princ ipa is efeitos. [12].

Tabela 4 - Princ ip a is elementos de liga e sua simpurezas.

\begin{tabular}{cclll}
\hline Elemento & Concentração & \multicolumn{2}{c}{ Efeito } \\
\hline \multirow{2}{*}{ MAGNÉsio } & No Al 17,4\% & Liga Comercial \\
& $5,5 \%$ & \begin{tabular}{l} 
Aumento da rignificativo da ductilidade. Provoca a precipitação \\
\hline
\end{tabular}
\end{tabular}




\begin{tabular}{|c|c|c|}
\hline & & de $\mathrm{Mg}_{2} \mathrm{Si}$, que é uma fase endurecedora. \\
\hline FERRO & $\approx 0,04 \%$ & $\begin{array}{l}\text { Impureza mais comum no alumínio. Apresenta-se na } \\
\text { forma de compostos intermetálic os grosseiros, em } \\
\text { combinação com o Al e outros elementos. }\end{array}$ \\
\hline Siúcio & 0,01 a $0,15 \%$ & $\begin{array}{l}\text { Depois do Fe, é a impureza mais comum no Al } \\
\text { comercial. É também o principal elemento de liga } \\
\text { para ligas fundidas; em ligas trabalháveis é } \\
\text { usualmente empregado juntamente com o Mg, } \\
\text { produzindo asligasenvelhecíveis da série } 6 \text { XXX. }\end{array}$ \\
\hline MANGANÊS & $0,10 \%$ & $\begin{array}{l}\text { Efeito endurecedor, Controla a estrutura de grãos, } \\
\text { além de aumentara resistência mecânica. Dificulta a } \\
\text { recuperação e inibe a recristalização e o } \\
\text { crescimento de grão. Principal elemento da série } \\
\text { 3XXX. }\end{array}$ \\
\hline COBRE & 2 a $10 \%$ & $\begin{array}{llcc}\text { Impureza na liga de Al-6063. } & \text { Favorece } \\
\text { endurecimento por precipitação } & \text { durante } \\
\text { envelhecimento. } & & & \end{array}$ \\
\hline
\end{tabular}

Aumenta a resistência (em teores de até $2 \%$ ), porém Níque $\quad 0,04 \% \quad \mathrm{Si}$ para aumentar a dureza e resistência em temperaturas elevadas e para reduzir o coeficiente de expansão térmica.

A a dição de outros elementos ( $\mathrm{Mg}$ e $\mathrm{Cu}$ ) juntamente com o Zn produz ligas de Al de ma is a lta resistência Znco $\quad 0,04 \%$ mecânica. Adições em quantidade diminuta de $\mathrm{Cr}$, Zn ou Mg têm efeito significativo no aumento da resistência destas ligas, pelos seus efeitos sobre a estrutura de grãos.

\begin{tabular}{cll} 
Cromo & $0,35 \%$ & $\begin{array}{l}\text { Impureza no Al de pureza comercial, com grande } \\
\text { influência sobre a resistividade elétrica. }\end{array}$ \\
\hline ThâNIO Até 100ppm & $\begin{array}{l}\text { É usado principalmente como elemento refinador } \\
\text { dos grãos em peças fundidas e em lingotes, } \\
\text { utilizando-se, também, o Boro em conjunto com o Ti } \\
\left.\text { (na forma de TiB } B_{2}\right), \text { para esta finalidade. }\end{array}$ \\
\hline
\end{tabular}

\section{4 - Processos Termomecânicos}

O processamento termomecânico, isto é, a conformação plástica a frio ou a quente e os tratamentos térmicos (recozimento) 
aplicados controladamente irão definir a microestrutura, e as propriedades dos meta is e suas ligas.

De toda a energia empregada durante a deformação plástica, a maior parte desta energia é perdida na forma de calor e parte ficará retida na forma de defeitos, lacunas, discordâncias e maclas, proporcional ao aumento da deformação aplicada. Essa energia retida toma o material temodinamicamente instável. $\mathrm{Na}$ etapa de deformação plástica a frio, somente 2 a $10 \%$ [13] de toda a energia a plicada é retida no corpo fic ando na forma de defeitos cristalinos levando, principalmente ao endurecimento do material, encruamento, ou seja, diminuindo a ductibilidade e aumentando a tensão de escoamento.

Mesmo que termodinamicamente haja tendência da energia retida se dissipar, na prática, a redução da densidade dos defeitos gerados é muito lenta, sem tratamento témico. Os processos de tratamento térmico (recozimento) são utilizados para acelerar a dissipação dessa energia provocando a recuperação, recristalização e crescimento de grãos no material.

A etapa de recuperação é formada por um conjunto de fenômenos que determinarão a diminuição da quantidade dos defeitos gerados durante a deformação plástica, porém, sem a ocorência da migração de contomos de alto ângulo[14]. Nesta etapa, parte das propriedades origina is é restaurada.

Diferentemente da recuperação, a recrista lização de um metal ou liga deformada está associada a uma série de fenômenos que desenvolvem uma nova estrutura em função da fomação e migração de contomos de alto ângulo gerando novos grãos livres de discordâncias. A quantidade de energia amazenada durante a etapa de deformação plástica é um parâmetro importante para a ocorência dos mecanismos de recristalização. 
Com o término da recristalização ocorre a migração dos contomos de alto ângulo, pois a microestrutura ainda não está está vel. Essa série de fenômenos leva ao crescimento de grãos com a diminuição do número de grãos por unidade de volume.

Mesmo podendo ser analisados e definidos individualmente, esses fenômenos ocorrem, simultaneamente ou quase, já que os materia is a presentam, em geral, uma significa tiva heterogeneidade mic roestrutural.

\section{1 - O ESTADO ENCRUADO}

O estado encruado é resultado do processo de deformação mecânica tanto a quente quanto a frio. $O$ resultado mais notado desse processo é o aumento da dureza do materia|[15].

Os fenômenos de recuperação e recristalização são deteminados pela quantidade de energia amazenada durante os processos de deformação plástica. Dessa forma, a condição microestrutural do estado encruado irá deteminar o desenvolvimento, o crescimento e a orientação dos núcleos que origina rão os grão durante a recristalização. A mic roestrutura do metal deformado será afetada em função da pureza do material, sua orientação, temperatura, taxa e grau da deformação.

Os materia is não se comportam da mesma forma, e um dos fatores que determinam o comportamento de defomação da mic roestrutura do metal é a Energia de Defeito de Empilhamento (EDE)[13]. Metais com baixa EDE tendem a formar uma distribuição mais homogênea das discordâncias (Figura 1), porém, com menor mobilidade, isto é, as discordâncias têm ma is dificulda de de se aniquila rem, pois estão muito afastadas entre si. O resultado é a dificuldade de ocorrer fenômenos do tipo escorregamento cruzado (cross-slip) e escalagem de discordâncias (climb). Materia is com alta EDE apresentam uma 
distribuição de discordâncias com uma associação muito grande entre elas (Figura 2). Essa associação faz com que as discordâncias tenham maior mobilidade facilitando a aniquilação das discordâncias de sinais opostos. Daí o fato de metais com elevada EDE apresentarem menor densidade de discordâncias que um metal de baixa EDE, quando considerado um mesmo grau de deformação. O alumínio é um metal c.f.c. com a lta EDE, $163 \mathrm{erg} / \mathrm{cm}^{2[16]}$.

A presença de elementos adicionados à solução sólida a ltera a EDE inicial do metal, alterando a distribuição das discordâncias e, por conseguinte, as propriedades deste materia [1]3].

Figura1. Representação da distribuição homogênea de discordâncias em metais de baixa EDE. São nomalmente cúbicos de corpo centrado, c.c.C.
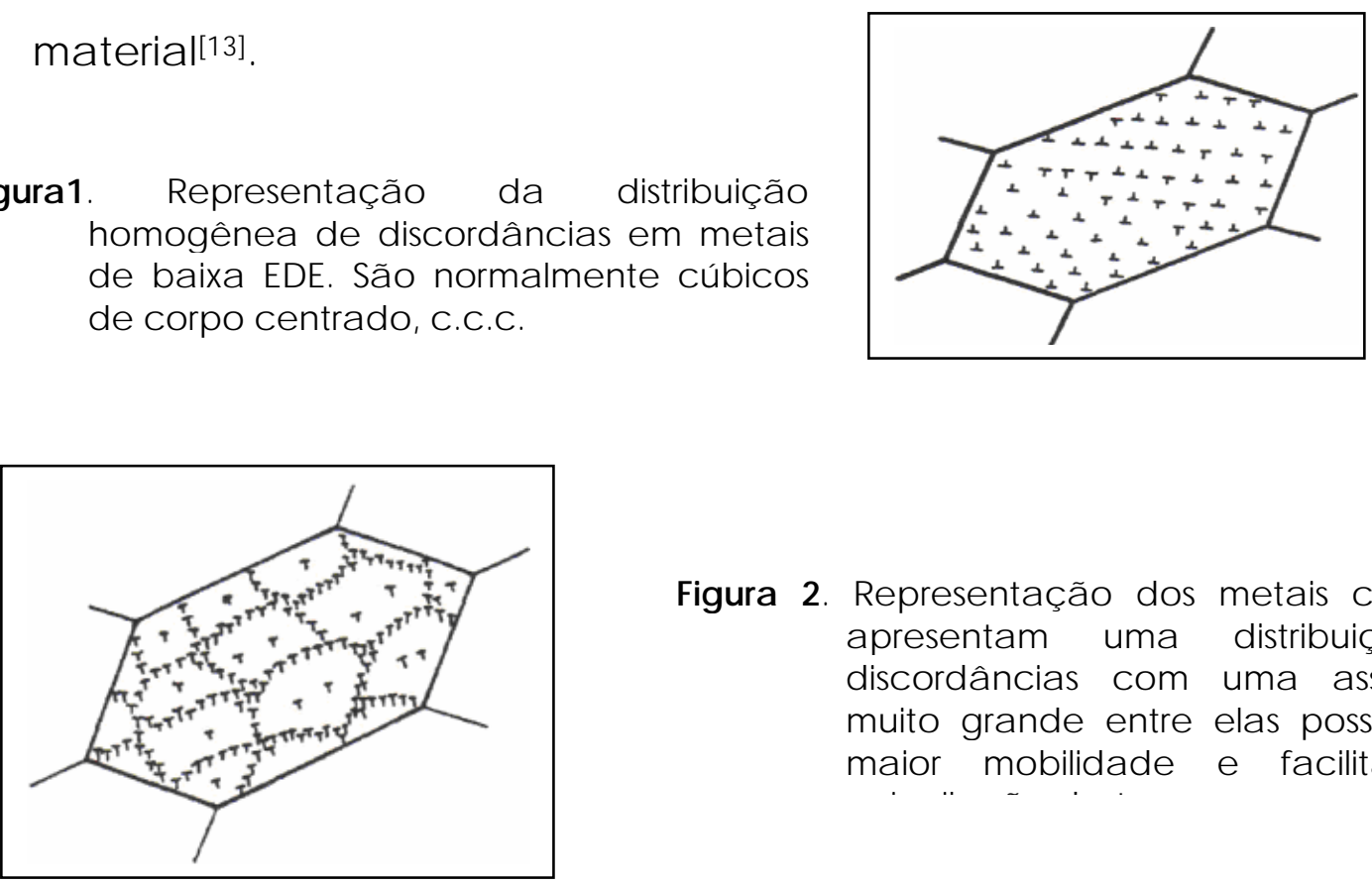

Figura 2. Representação dos metais c.f.c. que apresentam uma distribuição de discordâncias com uma associação muito grande entre elas possibilitando maior mobilidade e facilitando a

A temperatura na qual se conduz o encruamento tem papel crucial nas alterações mic roestrutura is do material. Pequenas alterações na temperatura produzem grandes alterações na microestrutura do material. $O$ encruamento em temperaturas baixas tende a diminuir a mobilidade das discordâncias além de diminuir a EDE[13]. Isso significa diminuir a ductilidade do material. 
A etapa de deformação plástica do material introduz uma série de alterações na mic roestrutura [13]. A forma inicial dos grãos será mudada para uma mais alongada, sendo que a área de contomo dos grãos aumentará significativamente, incorporando parte das discordâncias geradas durante a deformação. Interiomente os grãos também sofrem a lterações com o desenvolvimento de subestruturas antes inexistentes.

Como mencionado, os fenômenos de recuperação e recristalização são dependentes da microestrutura desenvolvida com os processos de deformação plástica. Metais com elevada EDE tendem a desenvolver, de um modo geral, estruturas de discordâncias com baixa energia altemando entre regiões com elevada densidade de discordâncias (paredes de células) e regiões de baixa densidade de discordâncias (interior de células e subgrãos), chamadas de Low-Energy Disloc ations Struc tures, LEDS[17].

Numa escala mais abrangente, a classificação dos grupos de células de discordâncias (Cell Blocks, CBs), para pequenas e médias deformações ( $50 \%$ de deformação) pode ser dada por elementos de volume chamado de paredes de discordâncias densas (Dense Dislocation Walls, DD Ws) e microbandas (Microbands, MBs). Quando são consideradas deformações bem ma is signific ativas, as alterações tomamse mais pronunciadas tomando as células de discordâncias mais achatadas, surgindo os contomos de alto ângulo chamados lamelares (Lamelar Boundaries, LBs) em substituição aos DDWs e MBs [18]. Estas estruturas terão papel fundamental no processo de recuperação em ligas de alumínio encruado.

Os contomos de discordâncias incidenta is (Incidental Dislocation Boundaries, IDBs), são origina dos das paredes das célula s que, por sua vez, são formados quando as discordâncias interagem entre si, de modo absolutamente aleatónio, compartilhando os mesmos sistemas de deslizamento e posterior emaranhamento. As diferenças crescentes nas orientações entre as diferentes partes do cristal oriundas do processo de 
deformação são acomodadas pela presença dos DDWs, MBs e LBs. Esses contomos são classificados como Geometrically Necessary Boundanes, GNBs. No material em deformação, a separação entre os GNBs e IDBs diminui com o aumento da força aplicada. Inversamente, o aumento da força aplicada, isto é, o aumento da deformação tende a diminuir a diferença de orientação entre as regiões limita das por esses contomos.

Num processo onde a deformação plástica é sempre crescente, regiões com predominância da microestrutura lamelar tendem a produção de contomos de grãos de alto ângulo dividindo em regiões distintas. Após deformações da ordem de 90\%, um metal de alta EDE apresenta um número de contomos de alto ângulo maior que o número inicial de contomos de grãos. Esse comportamento pode ser observado na deformação plástica de polic rista is. Bay e col., em 1992, observaram que, para pequenas deformações da ordem de 10 a 50\%, o alumínio de alta pureza laminado a frio apresentava uma microestrutura fomada de células de discordâncias, blocos de células (Cell Blocks, CBs), DDWs e MBs.

Nos metais de alta EDE, pequenas deformações da ordem de10\%, apresentam uma microestrutura predominante de células que evolui para uma onde há predominância de blocos de células, DDWs e MBs quando deformadas entre 20 e 50\%. Com a elevação da deformação para cerca de 70\%, a estrutura das células e blocos de células passam a apresentar uma forma alongada agrupando-se em estruturas lamelares, formando ângulos entre 0 e $15 \%$ em relação à direção de laminação. Estas estruturas, porém, representam apenas $25 \%$ da estrutura total.

Aplic ando-se deformações elevadas, da ordem de 80 a $90 \%$, as estruturas intermediárias desaparecem predominando os contomos lamelares paralelos à direção de laminação. As lamelas são separadas entre si por contomos lamelares, LBs, e geralmente apresentam uma única célula resultante dessa intensa deformação. No alumínio, metal com elevada EDE, observa-se a ocorência da recuperação dinâmica quando 
a plica do $90 \%$ de deformação, caracteriza do pelo surgimento de subgrãos equiaxia is.

A análise dos fenômenos, individual e coletiva, leva a um modelo onde a deformação aplicada pode ser acompanhada pela evolução da microestrutura de materiais com caractenísticas distintas no que diz respeito a estrutura cristalina e EDE[18], (Hughes e Hansen, 1997, Hughes, 1993, Hughes e Hansen, 1993).

Para a melhor compreensão desses fenômenos, a Figura 3 a presenta um esquema com a representação das estruturas formadas.

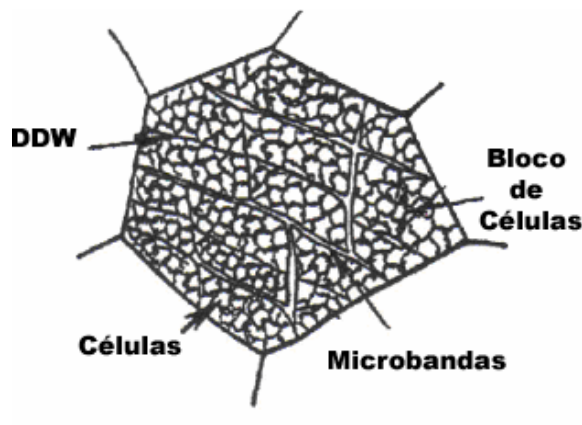

(a) Deformações Intermediárias

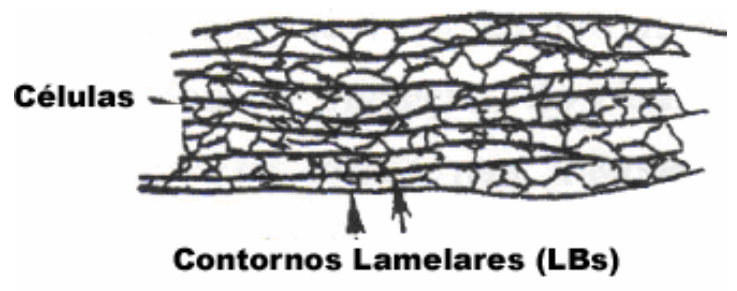

(b) Grandes Deformações

Figura 3. (a) Microestrutura de um grão submetido a deformações intemediárias $(0,06<\varepsilon<0,80)$;

(b) $O$ mesmo grão após uma grande deformação $(\varepsilon>1)$.

4.2.1.- DEFORMAÇÃo HETEROGÊNEA NA MiCROESTRUTURA

De uma forma geral, os materia is, mesmo os de alta pureza, não apresentam uma estrutura homogênea. Assim, para o alumínio, os processos de deformação plástica geram uma estrutura heterogênea, devido à ocorrência de deslizamentos de diversas origens[18]. Dessa forma, a distribuição de defeitos cristalinos em um material encruado é heterogênea o que leva a concluir que muitas caracteństicas dos materia is são devidas a essa heterogeneidade.

As regiões que contém maior quantidade de defeitos cristalinos são aquelas que apresentam heterogeneidade na formação. A partir dessas regiões é que são iniciadas as nucleações da recristalização, pois contém os núcleos potenciais formados durante a deformação plástica. 
Uma vez que os meta is têm ca racteństic as diferentes, na queles em que há formação de bandas de transição, de cisalhamento e maclas mecânicas, a nucleação deverá se iniciar nas intersecções das heterogeneidades ou próximas a elas ${ }^{[13,19,20] \text {. }}$

\section{3 - O TRATAMENTO TÉRMICO}

Os processos de produção do alumínio e fabricação de suas ligas levam, nomalmente, ao acúmulo de tensões residuais nesses materiais. Essas tensões podem ser prejudiciais para a seqüência de fabricação da peça ou mesmo para a sua vida útil[6]. Para que essas tensões sejam eliminadas ou minimizadas, são aplicados tratamentos térmicos de acordo com o tipo da liga, forma e tamanho das peças, processo de fabricação e condições de trabalho.

O recozimento do material encruado tem por finalidade alterar sua microestrutura, conseqüentemente, as suas propriedades. Essas alterações se dão principalmente com a diminuição da densidade das discordâncias devido à diminuição da energia retida e recuperação e/ou crista lização.

As condições do recozimento são fortemente dependentes dos parâmetros iniciais (condições do encruamento) e finais do material (propriedades desejadas), a lém da sua natureza própria (tipo do metal, composição química, fases, entre outras).

Nos meta is deformados a frio, as mudanç as mic roestrutura is que ocorrem logo após o recozimento, acontecem de maneira a diminuir a energia a mazenada na deformação plástica, e ocorre por mecanismos de redução e rearranjo de defeitos cristalinos, que se dão separadamente outros simulta neamente, podend o ocorrer de forma controlada ou mesmo sem qualquer controle. Os fenômenos que correspondem as mudanças 
mic roestrutura is são chamados de recuperação e recrista liza ção, que será estudado a seguir.

\section{4. - RECUPERAÇÃO}

A recuperação compreende fenômenos que levam a restauração parcial da microestrutura do material advinda da deformação plástica [22]. A recuperação ocorre de duas maneiras: durante - recozimento após as etapas de deformação plástica é classificada como recuperação estática, porém, quando ocorre durante a deformação plástica em temperaturas acima da ambiente é denominada recuperação dinâmica. O segundo caso é mais comum entre os metais de elevada EDE. Como as propriedades dos materia is estão intrinsecamente relacionadas ao seu estado microestrutural, a recuperação pode ser avaliada medindo-se as alterações nas propriedades mecânic as, resistividade elétric a e tensões residua is.

Para a restauração total ou parcial da microestrutura inicial, os fenômenos associados a o processo de recuperação estarão relacionados a o tipo do material e a sua pureza, à deformação aplicada a o material e às temperaturas aplicadas durante as etapas de deformação plástica e de recozimento. Assim, a aniquilação de lacunas e migração de defeitos puntiformes em direção a os contomos de grãos e discordâncias ocomerá em temperaturas acima de 0,2. $T_{f}$, onde Tf é a temperatura absoluta de fusão. Na região entre 0,2 a 0,3.Tf os fenômenos predominantes serão a a niquilação e rearranjo de discordâncias de sinais opostos fazendo com que os subcontomos dos grãos se tomem mais aparentes, o que irá caracterizar uma estrutura de contomos de baixos ângulos[19]. Outras estruturas, como a formação de subgrãos somente ocorrem em temperaturas superiores, noma Imente acima de 0,4.Tf, quando há energia suficiente para que o escorregamento e a escalada ocorram em grande escala. 
OS ESTÁGIOS DA RECUPERAÇÃo

\subsection{1 - ANIQUILAÇÃO DAS DISCORDÂNCIAS}

São dois os fenômenos principais que levam à aniquilação de discordâncias. Primeiro, quando discordâncias que atuam no mesmo plano de escorregamento, porém com sinais opostos, deslizam uma em direção à outra. E segundo quando discordâncias em planos de escorregamento diferentes e com vetores de Burgers opostos, combinam escorregamento e escalada para se aniquilar. Neste caso, só ocorre em temperaturas elevadas, pois há necessidade de maior energia para que a escalada ocorra. A representação desses fenômenos é apresentada na Figura 4.

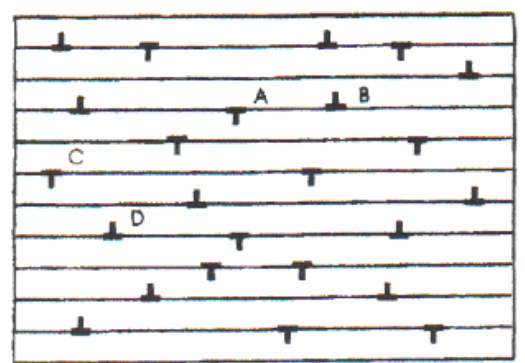

Figura 4. Representação de uma distribuição de discordâncias em cunha onde ocorre a a niquilação de discordâncias de sinais opostos, A e B, e a niquilação de disc ordâncias com vetores de Burgers opostos em planos distintos, C e D.

\subsection{2. - CONFIGURAÇÕES ESTÁVEIS DE DISCORDÂNCIAS}

Poligonização: Considere a distribuição de discordâncias produzida pela flexão de um cristal simples e que foi deformado com um único sistema de deslizamento, Figura 5. Se a distribuição envolver uma quantidade desigual de discordâncias de sinais opostos, estas não poderão ser aniquiladas totalmente, remanescendo a diferença que, durante o processo de recozimento será rearranjada em uma ou ma is configuração de menor energia. Esses a rranjos assumem configurações regulares ou estarão presentes em contomos de baixo ângulo.

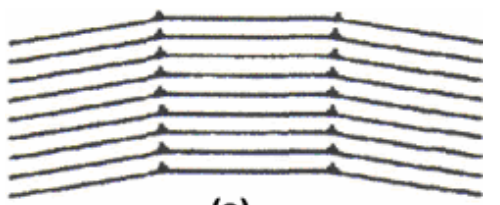

(c) 


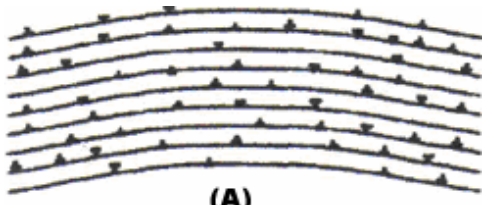

(A)

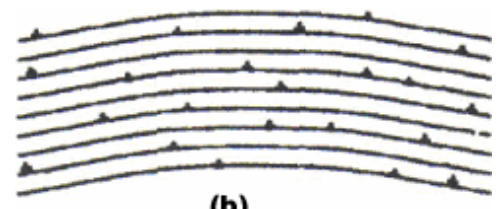

(b)

(b) a niquilação de sinais opostose,

(c) rearranjo das discordância s remanesc entes em um arranjo geométrico.

Formação de subgrãos: A a plic ação de quantida de de energia crescente irá resultar em grandes deformações na mic roestrutura inicial introduzindo discordâncias que se distribuirão em a ranjos complexos e com diferentes vetores de Burgers. Essa é uma situação real para um material polic ristalino. No caso do a lumínio, material de elevada EDE, ou em outros com EDE moderada, forma-se uma estrutura na forma de células com uma elevada densidade de discordâncias. Nessa condição, as paredes dessa estrutura celular apresentam uma distribuição desordenada das discordâncias formadas sendo as dimensões das células dependentes da natureza do material e da quantidade da deformação produzida.

A formação de subgrãos pode ser observada em uma seqüência de duas micrografias ${ }^{[19]}$, Figura 6 , obtidas por um microscópio eletrônico de transmissão de alta voltagem (HVEM). As imagens são de uma amostra de alumínio defomada a 10\%. Na primeira imagem (a) observa-se que a estrutura resultante da deformação plástica é constituída por células cujas paredes são constituídas por discordâncias desordenadas e pela presença de quantidade significativa de discordâncias no interior das mesmas. O processo de recozimento in situ (250 ${ }^{\circ} \mathrm{C}$ por 2 minutos), ou seja, no interior do mic roscópio eletrônico, levou ao a niquilamento de discordâncias, resultando em subgrãos definidos, diminuição da densida de de discordâncias no interior dos subgrãos e uma pequena alteração na natureza e na orientação dos contomos formados, imagem (b). 


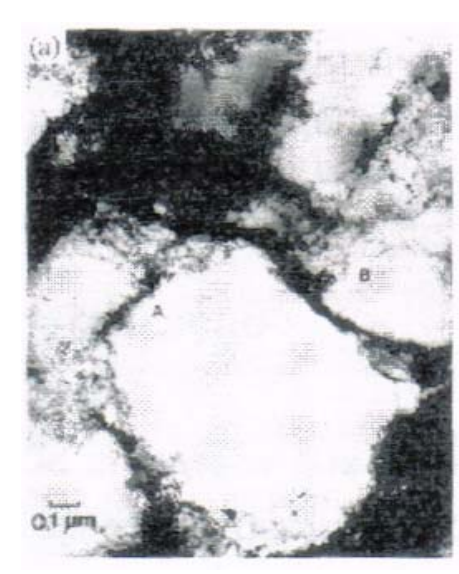

(a)

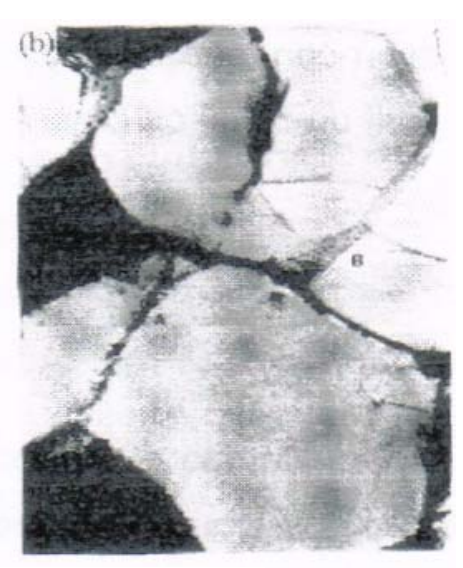

(b)

Figura 6. Mic rografia de uma amostra de alumínio deformada a $10 \%$ obtida em microscópio eletrônic o de transmissão.

(a) apósa deformação e

(b) a pós tratamento a $250{ }^{\circ} \mathrm{C}$ por 2 minutos. A recuperação se deu pela formação de subgrãose definição dos contomos.[19]

\subsection{3 - CRESCIMENTO DE SUBGRÃOS}

A etapa seguinte à formação de subgrãos é o seu crescimento[23]. O crescimento dos subgrãos leva à diminuição da área dos contomos de baixo ângulo e ocorre somente porque a energia no material recuperado ainda continua alta, já que o material totalmente recristalizado apresenta uma subestrutura com menor energia, ou seja, ma is está vel.

O mecanismo mais aceito para explicar o crescimento de subgrãos baseia-se na migração de contomos de baixo ângulo. Durante a migração do subgrão ocorre a absorção de discordâncias provocando alteração na sua orientação gerando no final um contomo de alto ângulo. Por esse mecanismo fica mais evidente a formação de regiões de baixas densidades de discordâncias, uma vez que o mecanismo se baseia na poligonização, os efeitos são aniquilados rearranjando-se numa estrutura de baixa energia.

De uma forma geral, a recuperação constitui-se em um conjunto e processos regulares. As áreas afetadas por esse fenômeno têm um comportamento similar, sendo que as alterações ocomidas pelas células e subgrãos não são bem caracterizadas quanto ao início ou fim. 
Recuperação e recrista lização são dois fenômenos basic amente diferentes. Em um recozimento isotérmico, a velocida de com que ocorre o processo de recuperação sempre decresce com o tempo, isto é, o processo se inicia rapidamente e vai tomando-se cada vez mais lento, conforme vai sendo consumida a força motriz da reação. Por outro lado, a cinética da recristalização é bem diferente, pois ocorre por processos de nucleação e crescimento. Da mesma maneira que para outros processos desse tipo, a recristalização durante um recozimento isotérmico se inicia lentamente, aumenta a té um valor máximo de velocidade de reação, e logo após volta a ser lenta. O processo de recuperação se inicia no começo do ciclo de recozimento, justificando a liberação inicial de energia, enquanto a recristalização começa mais tarde, sendo responsável pela segunda liberação de energia, que é ma ior que a inicial.

Um termo metalúrgico usado freqüentemente é "temperatura de recristalização", isto é, a temperatura na qual um determinado metal, com uma certa porcentagem de deformação a frio, recristalizará totalmente em um perído finito de tempo, esta temperatura depende, do tempo de aquecimento, pois, períodos de tempo mais longos dão aos átomos a oportunidade de se rearranjarem, portanto, a recristalização ocorre normalmente em temperaturas mais baixas, conseqüentemente, a temperatura necessária para a recristalização depende das forças que mantêm os átomos unidos, considerando-se o fato de que a energia térmica necessária para a fusão está relacionada com as forças entre os átomos. Dessa forma, é de se esperar que haja correlação entre a temperatura de fusão e a de recristalização, embora existam exceções, a temperatura de recristalização está entre um terço e metade da temperatura absoluta de fusão[23]. 
Os processos que determinam e compreendem a recristalização do alumínio e suas ligas devem ser conhecidos uma vez que estão associa dos a vários fenômenos como a liberação da energia a mazenada durante o encruamento, o aumento da densidade, a diminuição da dureza e da resistividade, entre outros[13].Esses fenômenos afetam a facilidade com que o material pode ser trabalhado e as suas caracteństicas pós esse trabalho, deteminando a sua correta aplicação ou não.

O processo de recristalização pode ser entendido como o resultado de um conjunto de alterações na microestrutura de um material em decorrência de tratamento térmico onde os grãos formados estão livres de defeitos, ou seja, com menor energia acumulada[25]. Esse processo pode levar à formação de grãos de dimensões fora do comum, assim, o conjunto de fenômenos que levam à formação dos grãos é chamados de recrista liza ção primária, Figura 7, e o posterior c rescimento dos grãos até tamanhos exagerados é conhecido por recristalização secundária ou também de crescimento anomal de grão, também pode ser interpretado como a eliminação de defeitos na microestrutura por migração de contomos de alto ângulo. Uma região livre de defeitos associada a um contomo de alto ângulo pode crescer avançando sobre as regiões encruadas. A recristalização, isto é, a migração de contomos de alto ângulo prossegue a té que os grãos formados se encontrem. Nesta situa ção, a recristalização primária está teminada.

O processo de recozimento de algumas ligas pode conduzir ao seu amolecimento sem que haja a formação e migração dos contomos de a to ângulo. 


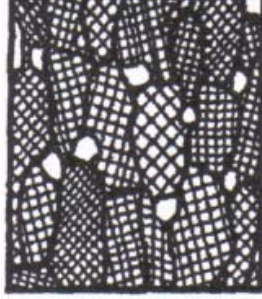

(a)

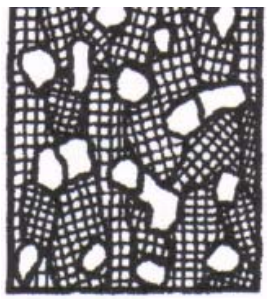

(b)

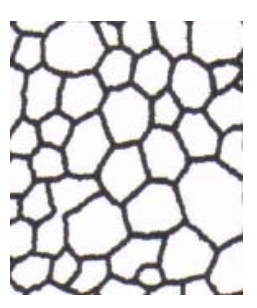

(c)

Figura 7. Representa ção esquemática da recrista liza ção primá ria.

(a) O material encruado a presenta indícios do iníc io da recristalização com a formação de grãos livres de defeitos.

(b) O processo segue com o aumento considerável do número de grãos livres de defeitos;

(c) Temina com o encontro dos contomos de alto ângulo, o que caracteriza o fim do processo de recristalização do ma terial.

Uma interpretação generalizada dos fatores que deteminam o processo de recristalização nas chamadas Leis da Recristalização[13]. Nessas condições, a recristalização do material é aceita em função do tamanho os grãos na microestrutura inicial e da quantidade de deformação e temperatura de recozimento. Considerando-se a recristalização como um processo dominado pêlos fenômenos de nucleação e crescimento de grãos resultantes de processos de tratamentos témicos controlados, essas leis podem ser aplicadas para a maior parte doscasos.

\section{LEIS DA RECRISTALZAÇÃo}

1) "Para que a recristalização ocorra é necessária uma deformação mínima",

2) "Quanto menor o grau de deformação, mais alta é a temperatura para o início da recrista liza ção",

3) "Quanto mais longo o tempo de recozimento, menor a temperatura para o início da recrista liza ção",

4) "O tamanho de grão final depende fortemente do grau de deformação e pouco da temperatura de recozimento. Quanto maioro 
grau de deformação e/ou menor a temperatura de recozimento, menor será o tamanho do grão final",

5) "Quanto maior o tamanho de grão inicial, maior será a deformação necessária para que a recrista lização se complete no mesmo intervalo de tempo e temperatura de recozimento",

6) "O grau de redução necessánio para se obter um mesmo endurecimento por deformação (encruamento) aumenta com o aumento da temperatura de deformação. Para um dado grau de redução, quanto maiorfora temperatura de deformação, maior será a temperatura de recristalização e maior será o tamanho de grão final",

7) "O aquecimento continuado após o témino da recristalização causa crescimento de grão"

\subsection{1 - NUCLEAÇÃo E RECRISTALIZAÇÃo}

Como mencionado, o início do processo de recristalização está associado à nucleação no materia|[24]. A nucleação da recristalização envolve mecanismos que irão levar ao rearranjo de discordâncias formando regiões livres de defeitos associadas a contomos de alto ângulo de alta mobilidade que têm a capacidade de migrar facilmente sobre a matriz encruada.

Dessa forma, a nucleação irá determinar o tamanho e a orientação dos novos grãos formados durante o processo de recristalização. Existem vários mecanismos que procuram explicar os mecanismos envolvidos na nucleação. A teoria clássica da nucleação homogênea não será discutida, uma vez que é improvável que ocorra, pois, o potencial temodinâmico associado à recristalização é baixo e a energia de interface de um contomo de alto ângulo é elevada impossibilitando a formação das regiões livres de defeitos associadas a contomos de alto ângulo. 
Migração de contomos existentes induzidas por deformação: Este mecanismo é aplicável para deformações menores do que $40 \%$ e considera que a migração de contomos preexistentes se dá para o interior de um grão mais defomado, Figura 8. Dessa forma, cria-se região livre de disc ordâncias com orienta ções simila res a os grã os inic ia is. Esse meca nismo ocorrerá somente se o balanço energético estiver favorável, isto é, se $E_{2}<$ $E_{1}$ a migração ocorrerá no sentido onde a densidade de discordâncias for maior criando regiões livres de defeitos, ou seja, de menor energia.

Crescimento a partir de núcleos preexistentes: Como a recristaliza ção pode ser iniciada a partir da existência de regiões livres de defeitos presentes após o encruamento tais como células de discordâncias ou subgrãos, os fatores envolvidos nesse mecanismo estão associados a:

1) Após o encruamento, os núcleos a presentam orientação definida não havendo observações de que haja formação de novas orientações durante ou após a nucleação.

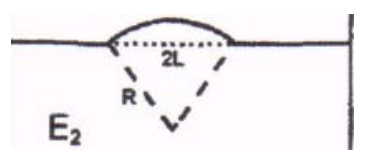

(a)

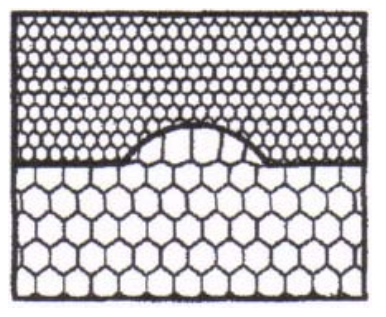

(b)

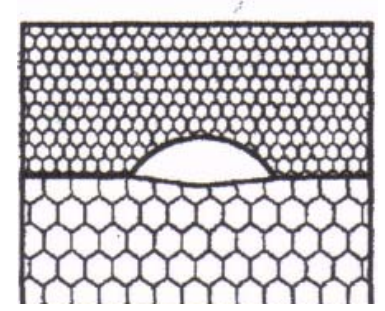

(c)

Figura 8. (a) Condições para a ocorência da migração de contomos: A energia do grão inferior $E_{2}$ deve ser menor do que a energia E1 do grão superior, (b) Migração do contomo para região de maior energia e (c) formação de região livre de defeitos com menor energia.

2) A nucleação se desenvolve com o crescimento de subgrãos baseados no mecanismo que envolve a formação de regiões de baixa densidade de discordâncias (poligonização) circundadas por subcontomos.

3) A formação de um contomo de alto ângulo está associada à existência de um gradiente de orientação. As regiões do material onde existem 
diferentes orientações de crista is ou um gradiente de orientação possuem alta energia amazenada. Nessas regiões, estão presentes contomos de baixo ângulo ou discordâncias que satisfazem geometricamente a acomodação de diferenças de orientação. Nessas condições os fenômenos de recuperação são preferencia is.

A partir desses fatores, todo o processo de nucleação da recristalização será considerado como um conjunto de fenômenos que levarão ao crescimento descontínuo de subgrãos existentes em regiões com alta deformação e com um gradiente de orientação significativo.

\subsection{2. - CINÉTICA DE RECRISTALIZAÇÃO}

A recristalização pode ser tratada como um processo de nucleação segundo o modelo de cinética de Johnson-Mehl., supondo que, dependendo da temperatura, inicialmente existirão $\mathbf{N}$ domínios de núcleos por unidade de volume, ou seja, locais onde preferencialmente ocorrerá a nucleação. Este volume aumentará em todas as direções a uma taxa constante $\mathbf{v}$ até que os domínios entrem em contato uns com os outros.

Sendo a expressão geral dada por:

$$
X=1-\exp \left[-\frac{4}{3} \pi v^{3} N(t) t^{3}\right] \quad \text { Equação }
$$

Onde: $\quad$ X... fração ordenada;

v... volume;

N... número de núcleos por unidade de volume;

t...tempo

Como a relação entre a fração recristalizada (ordenada) e tempo é exponencial, pode-se optarportempos de tratamento que segam este fator. 


\subsection{3. - RECRISTALIZAÇÃO DE LIGAS NA PRESENÇA DE SEGUNDAS FASES}

Adição de elementos a metais proporciona três de situações distintas no que conceme aos elementos de liga, do ponto de vista da recrista lização o[15]:

1) Os elementos de liga encontram-se em solução sólida;

2) Os elementos de liga encontram-se na forma de precipitados de segunda fase;

3) Os elementos de liga encontram-se na forma de uma segunda fase e a fração volumétrica desta segunda fase é alta.

Os efeitos desses elementos de segunda fase sobre a recristalização podem tanto estimular, como retardar a recrista liza ção, dependendo do modo como a partícula interage com a microestrutura durante o processamento temomecânico.

Em ligas com dispersão de precipitados de segundas fases existem evidências que mostram o a traso do processo de recristalização. Ta is partíc ulas atuam como ba rreiras para a movimentação dos contomos de alto ângulo devido à força de ancoramento exercida pelas partículas sobre os contomos de grão. Se esta força for maior que a de movimentação de contomos, não haverá migração e, conseqüentemente, o núcleo de recristalização não poderá crescer, impedindo a recrista liza ção[15,16].

Trabalhos recentes mostram que a adição de zircônio a ligas AlMg atua ativamente nestes processos.

Em ligas supersaturadas e com defeitos cristalinos, partíc ulas de segunda fase (tais como nas ligas Al-Mg-X, onde $X$ é um microligante) precipitam na mesma faixa de temperatura na qual a recristalização pode ocorrer. Desta forma, precipitação e recristalização exercem influências mutuamente. As partículas que se precipitam impedem o rearranjo de discordâncias que irão dar lugara frentes de recristaliza ção e 
a sua subseqüente migração. Os defeitos presentes na rede cristalina aceleram a nucleação de determinadas fases que por sua vez pode afetar rearranjos de discordâncias e a migração de contomos de grão. Somente quando a recristalização é completada, antes do início da precipitação, as duas reações oc orrerão independentemente $[6,8]$.

\subsection{4 - ReCRISTALIZAÇÃo SeCUNDÁRIA E CRESCIMENTO DE GRÃO}

Ao completar o processo de recrista liza ção, a mic roestrutura dos grãos recristalizados não está totalmente estabilizada, dando início à recrista lização secundária. Nesta etapa do recozimento, a quantidade de contomos passa a ter papel fundamental como potencial termodinâmico para o crescimento de grão diminuindo o número de grãos por unidade de volume devido ao aumento do seu tamanho, ou seja, diminuindo a área total dos contomos. Esse aumento do tamanho dos grãos pode ocorrer continuamente para todos os grãos ou de maneira diferenciada onde alguns grãos crescem mais que os outros e são denominados crescimento de grãose recrista liza ção secundá ria, respec tivamente.

Crescimento de grão: A recristaliza ção primária e o crescimento de grãos são fenômenos ativados temicamente. O potencial temodinâmico necessário para a ocorência da recristalização primária é cerca de duas ordens de grandeza superior do que a necessária para o crescimento de grãos. Em conseqüência disso, a velocidade de migração de contomos durante a recristalização primária é maior do que durante o crescimento de grãos. No caso de haverem dois grãos vizinhos de tamanhos diferentes, o potencial termodinâmico será maior quanto maior for a diferença entre os tamanhos desses grãos.

Recristalização secundánia: Com o término da recristalização primária, alguns grãos podem continuar crescendo além do que os demais, caracterizando um crescimento anomal de grãos também chamado de recristalização secundária. Os fatores que deteminam esse crescimento 
anomal são a heterogeneidade do tamanho de grão, a dispersão de partículas, a textura pronunciada e a espessura da amostra. 


\section{5 - TÉCNICAS UtILIZAdAs No Estudo DA RECRISTALIZAÇÃo}

O estudo da recristalização freqüentemente exige a utilização de várias técnicas complementares. As técnicas utilizadas neste estudo são apresentadas a seguir.

\section{1. - MICROSCOPIA ÓPTICA}

É a técnica mais antiga de observação metalográfica e ta mbém a mais difundida.

A microscopia óptica, entre outras técnicas de microscopia, destina-se às observações nas qua is o a umento é gera Imente menor que 1500 vezes, sendo, portanto, uma técnica destinada à observação de caractenísticas microestrutura is micrométricas. Por meio desta técnica pode-se observar contomos de grão e contomos de subgrãos (em alguns casos).

A observação é feita, num microscópio de reflexão tal como mostra a Figura 9[12].

A preparação da superfície a ser observada segue os seguintes passos:

1) Lixamento da superfíc ie tota Imente plana da a mostra;

2) Polimento, que pode ser manual ou mecanizado usando-se substâncias abrasivas muito finamente dispersa numa solução lubrific ante, ou polimento eletroquímico onde a amostra sofre um ataque eletroquímico numa solução eletrolític a contendo um catôdo e a amostra como sendo a nôdo. Em ambos os casos os objetivos são: nivelar a superfície, isto é atenuar as 
irregularidades microscópicas, e em segundo lugar, espelhar a amostra, principalmente do ponto de vista microscópico.

3) Ataque químico da superfície polida de forma a realçar certos constituintes da mic roestrutura de forma a toma-los observável ao microscópio óptico.

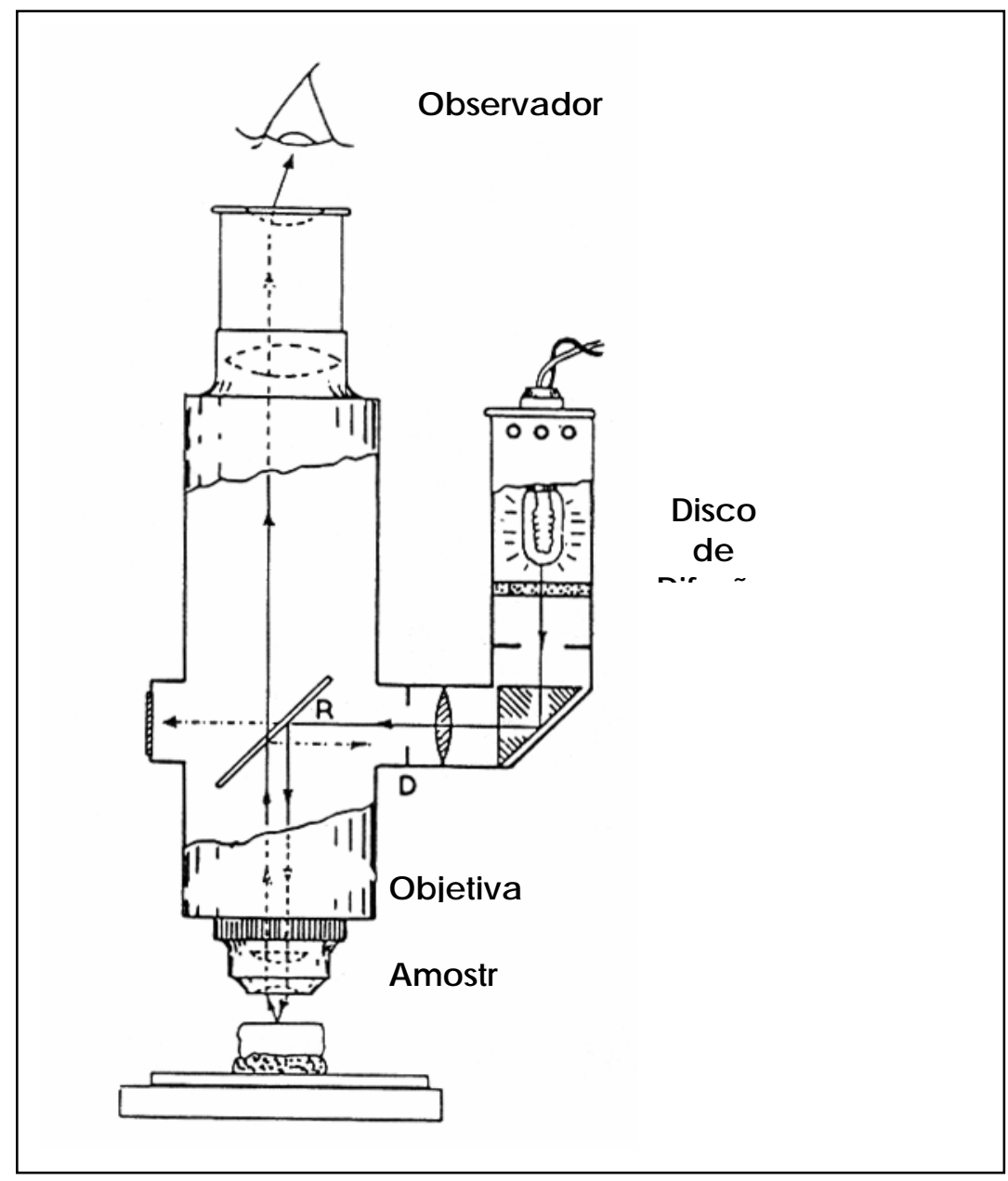

Figura 9. Representação esquemátic a de um mic roscópio óptico.

5.2 - MiCROSCOPIA ELETRÔNICA 
A técnica da microscopia eletrônica é muito interessante para estudos mic roestrutura is em virtude da capacidade de produzir grandes a umentos das imagens. Esta técnica baseia-se na interação de elétrons com a matéria e as informações geradas dessa interação. Os fenômenos que

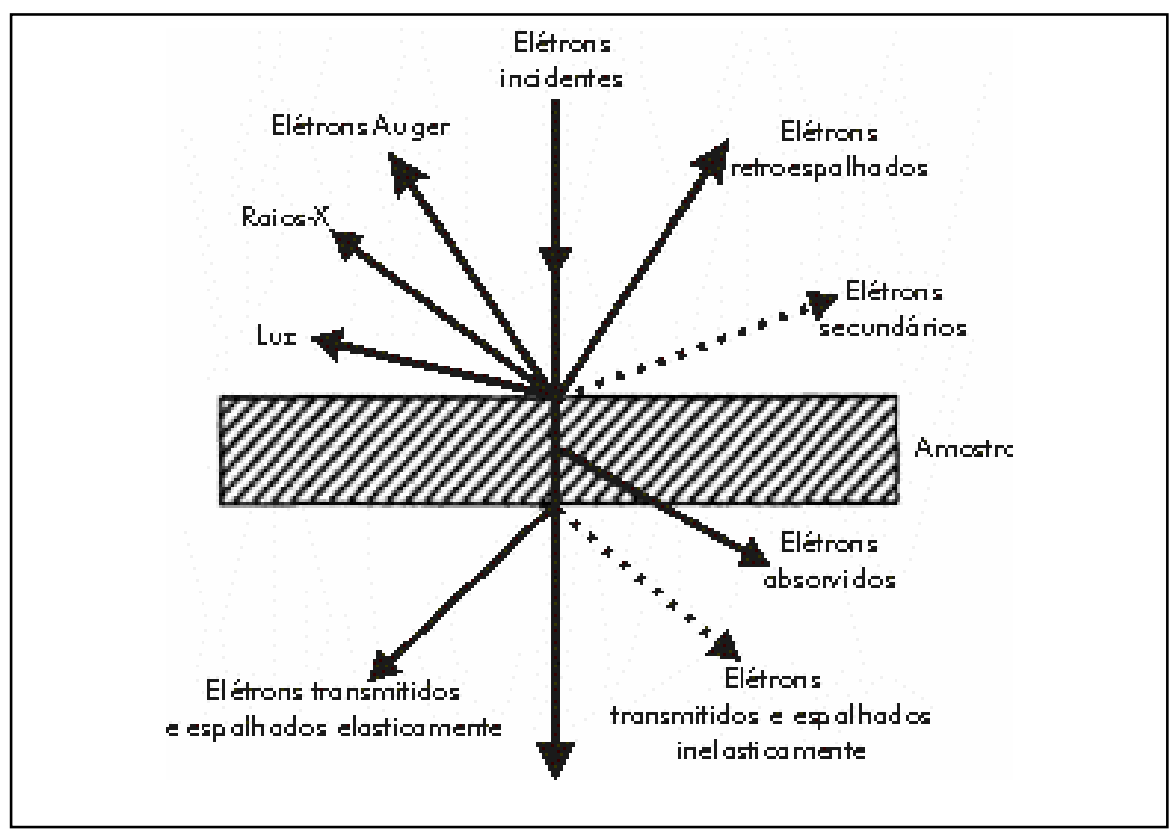

ocorrem durante essa interação são representados na Figura 10.

Figura 10. Interação de elétrons com a matéria e os fenômenos associados. 


\subsubsection{Mic roscopia Eletrônica de Transmissão. MET:}

A microscopia eletrônica de transmissão é uma das técnicas ma is utiliza das para a observa ção de estruturas em ma teria is metá lic os ou não. Isso se deve ao fato dos elétrons possuir comprimento de onda ma is curto do que a luz visível e, Dessa forma, poder interagir e trazer informações microestrutura is (defeitos puntifomes, contomos de grãos, falhas de empilhamento, espaçamento entre discordâncias, diâmetros de grãos e subgrãos, entre outros) do que as obsenadas em microscopia óptica. Como o próprio nome diz, a técnica utiliza os elétrons transmitidos e espalhados elasticamente pêlos núcleos dos átomos da amostra (os elétrons espa lha dos inelastic amente não são muito utiliza dos). 0 resultado dessa interação é basicamente a formação de imagem e de padrões de difração de elétrons. Mais uma vez, a preparação da amostra é uma etapa que deve ser realizada com muito cuidado. Nesta técnica, as amostras são nomalmente afinadas para que os elétrons possam passar através destas e serem transmitidos. O processo de afinamento é escolhido em função do tipo da amostra. No caso do alumínio, as a mostras devem ter, no máximo, uma espessura de $5000 \AA$.

Todavia, devido aos altos aumentos caracteństicos desta técnica, a representatividade da região obsenvada é baixa. Portanto, o uso do MET é caracterizar representativa recrista lização. 
Figura 11. Figura esquemática de um mic roscópio eletrônico de transmissão

\subsection{Ensaio de dureza}

Uma das propriedades mecânicas mais utilizadas na especificação de materiais, na engenharia mecânica é definida como a "resistência à penetração de um material duro no outro"[27].

Pode-se dividir o ensaio de dureza em três tipos principais, que dependem da maneira com que o ensaio é conduzido; (1) por penetração; (2) por choque; (3) por risco. O ensaio por penetração, é ma is largamente utiliza dos e diversos tipos de métodos aplicados, Brinell, Rockwell, Vickers, Knoop e Meyer, neste estudo focaremos o Método Vickers, utiliza do neste trabalho.

\section{Dureza Vickers}

Introduzida em 1925, utiliza-se um penetrador de diamante em forma de pirâmide de base quadrada, com um ângulo de 1360 entre as facesopostas Figura 12.

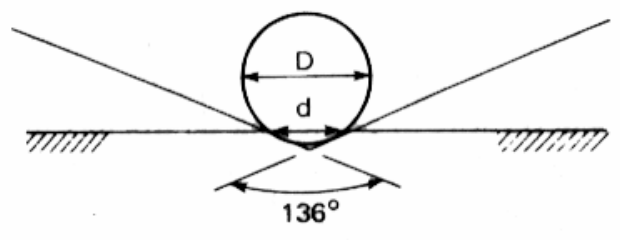


Figura 12. Ângulo das tangentes à esfera .

Sendo o penetrador, Figura 13, praticamente indeformável por ser de diamante, praticamente todas as impressões são semelhantes entre si, a dureza Vickers (HV) é independente da carga, isto é, o número de dureza obtido é o mesmo qualquer que seja a carga usada para materia is homogêneos. A forma da impressão é um losango regular, ou seja, quadrada, e pela média L das suas diagonais, tem-se, conforme a expressão seguinte, a dureza Vickers.

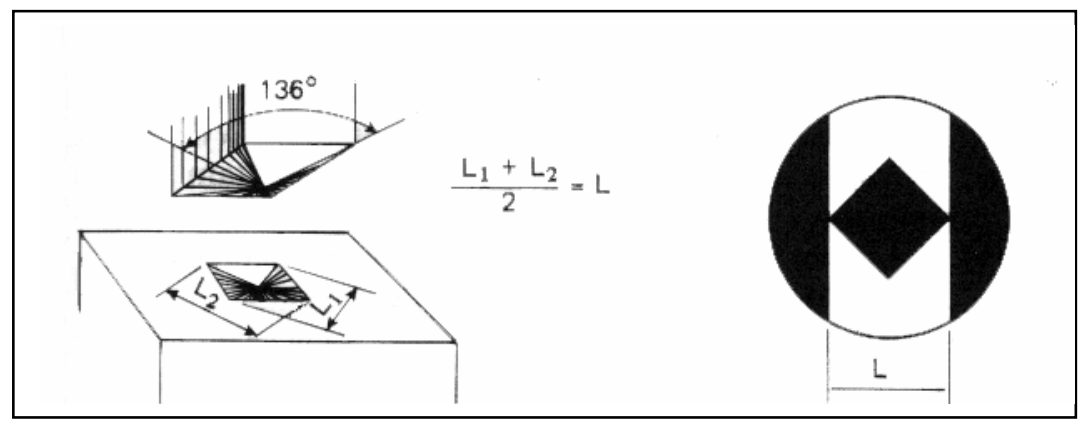

Figura 13. Penetradore impressão Vickers

Cálculo e unidades da medida de dureza Vickers:

$$
H V=\frac{c \arg a}{\text { área da sup erfície piramidal }}=\frac{2 Q \operatorname{sen} \frac{136}{2}}{L^{2}}
$$

ou seja,

$$
H V=\frac{1,8544 Q}{L^{2}} \quad \text { Equação } 2 .
$$

onde:

HV .... medida da dureza Vickers [N/ $\mathrm{mm}^{2}$ ou $\left.\mathrm{kgf} / \mathrm{mm}^{2}\right]$

Q ... carga utilizada [N ou kgf]

L.. diagonais, área medida [mm²] 
A área deve ser medida com precisão, e para esse fim existe um microscópio acoplado à máquina para a determinação das diagona is $L$. A carga é aplicada levemente na superfície plana da amostra, por meio de um pistão movido por uma alavanca e é mantida durante cerca de 18 segundos, depois do qual é retirada e o microscópio é movido manualmente a té que foca lize a impressão.

Vantagens do méto do Vickers:

1) Escala contínua;

2) Impressões extremamente pequenas que não inutilizam a a mostra;

3) Grande precisão de medida;

4) Deformação nula do penetrador,

5) Existência de a penasuma escala de dureza;

6) Aplicação para toda gama de durezas encontradas nos diversos materia is

7) Aplicação em qualquer espessura de material podendo, porta nto, medir durezas superfic ia is. 


\section{6. - Procedimento Experimental / Metodologia}

\section{1 - FuXograma.}

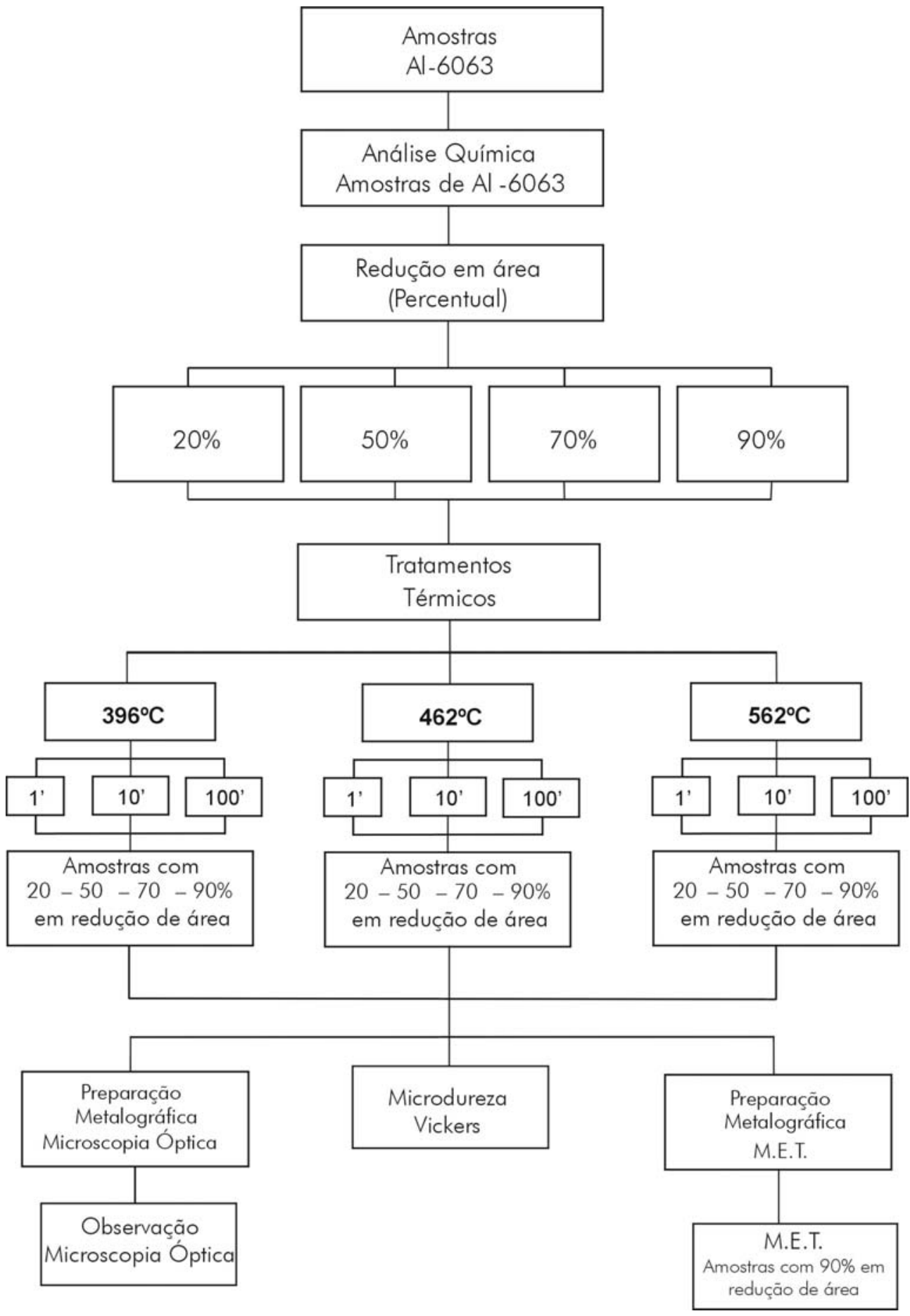




\section{2 - ANÁUSE QUÍMICA DAS AMOSTRAS DA UGA DE ALUMÍNIO 6063}

As amostras da liga de alumínio 6063 (Alcoa), utilizadas nestes experimentos, encontravam-se em forma de tarugo com área transversal a proxima da de $31,37 \mathrm{~mm}^{2}$ e $15 \mathrm{~cm}$ em seu comprimento.

Para caracterização química foram realizadas análises por Espectrometria de Fluorescência de raios-X (WDXRF)

\section{3 - Preparação - DeformaÇão das amostras por laminação a mio}

Foram retiradas amostras da liga de alumínio 6063, para la minação utilizou-se um laminador simples do tipo ourives com cilindros de $64 \mathrm{~mm}$ de diâmetro, disponível no Laboratónio de Metalurgia do Pó do CCTM.

A laminação das amostras ocorreu à temperatura ambiente utilizando-se incrementos de deformação constantes $(0,1 \mathrm{~mm}$ em cada passe), a té alcançarasáreas desejadas.

Foram la minadas a mostras com 20,50, 70 e 90\% em redução de sua área inicial.

\section{4 - TRATAMENTOS TERMICOS:}

Foram realizados tratamentos témicos pelas amostras de alumínio 6063 que passaram por processo de laminação a frio conforme descrito no item 6.3. O tratamento témico foi realizado em um fomo tipo mufla, Marca QUIMIS - Modelo 318D.

As amostras laminadas foram cortadas em chapas com cerca de $90 \mathrm{~mm}$ em seu comprimento. As amostras foram tratadas em temperaturas que obedeciam a seguinte característic $a: 0,6 T_{f}, 0,7 T_{f}, 0,8 T_{f}[11]$, com tempos de 60s, 600s, e 6.000s, e resfriadas com água e gelo, conforme descrição na Tabela 5 . 
Tabela 5 - Condições do Tratamento Témico

\begin{tabular}{|c|c|}
\hline $\begin{array}{l}\text { Temperatura de fusão ( } \text { (T⿱ }_{\text {f }} \text { da Liga Al- } \\
6063\end{array}$ & $660^{\circ} \mathrm{C}(933 \mathrm{~K})$ \\
\hline Temperaturas: 0,6 $\mathrm{T}_{\mathrm{f}}$ & $396 \div \mathrm{C}(669 \mathrm{~K})$ \\
\hline$-\quad 0,7 \mathrm{~T}_{f}$ & $462 \stackrel{\circ}{ } \mathrm{C}(735 \mathrm{~K})$ \\
\hline$-\quad 0,8 T_{f}$ & $528 \circ \mathrm{C}(801 \mathrm{~K})$ \\
\hline Tempo de tratamento (em segundos) & $60-600-6000$ \\
\hline Fomo utiliza do & Tipo mufla \\
\hline Resfriamento dasamostras & Água + gelo \\
\hline
\end{tabular}

\section{5 - Preparação de Amostras para Microscopia Ópica}

Ao témino dos tratamentos térmicos, as amostras foram novamente cortadas na ISOMET 2000 - fabricada por Buehler, para preparação metalográfica (Microscópio Óptico).

Os embutimentos das a mostras, com secção longitudinal, foram realizados em resina fria Epofix Resin, fabricada por Struers, evitando a possível alteração dos resultados do tratamento témico anteriomente realizado.

A preparação metalográfica das a mostras laminadase tratadas temicamente passou pela seqüência usual e preparação das amostras para M.O., que consiste no desbaste por lixamento (lixas no 400,600, 800, 2500 de granulometria) em seguida por uma série de panos de polimento com abrasivo (pó de diamante em suspensão) para polimento metalográfico, seqüência rea liza da $6 \mu \mathrm{m}, 3 \mu \mathrm{m}, 1 \mu \mathrm{m}$, fina lizando o processo com a slic a coloidal, para um melhor acabamento.

Finalizando a preparação, utilizou-se o método da dissolução eletrolítica, a solução utilizada como eletrólito foi: $700 \mathrm{ml}$ de etanol, $120 \mathrm{ml}$ 
de água destilada, 100ml 2butox etanol e $68 \mathrm{ml}$ ácido perclónico. O ataque eletrolítico foi feito no aparelho Electromet 4 - Electropolisher Cell Module - Buehler, disponível no Laboratório Metalurgia do Pó - IPEN, como catôdo foi utiliza do uma placa de aço inoxidável e a amostra de alumínio com fio de cobre, a ser dissolvida, serviu como a nôdo. O aparelho permite que se varie a tensão, com isso, pode-se escolher a voltagem de ataque. Optou-se por $12 \mathrm{~V}$ o que gerou uma densidade de corrente de aproxima damente $0,2 \mathrm{~A}$.

Para a obsenvação dos grãos, fez-se necessário atacá-las quimicamente, sendo que para o ataque foi utilizada uma solução de ácido fluońdrico ( $40 \% \mathrm{HF}$ diluído em água), com tempo médio de ataque de 60s.

Para a observação e registro fotográfic o utilizou-se o Microsc ópio Óptico Olympus BX60M, com câmera digital acoplada, marca Sony, modelo Hyper Had e software de registro DTAcquire.

\section{7 - ENSAIO MICRODUREA VICKERS}

Os ensaios da microdureza Vickers foram realizados em um microdurômetro Micromet da Buehler, instalado no Departamento de Engenharia Mecânica da EPUSP, com carga de 100g. Utilizaram-se amostras da liga de alumínio 6063, devidamente laminadas, tratadas e meta lograficamente preparadas, como anterio mente descrito.

As impressões foram feitas sufic ientemente espaçadas, de modo a não interferirem mutuamente. Foram feitas, pelo menos, 10 impressões em cada amostra, medindo-se as duas diagonais.

\section{7 - Medida de Tamanho Mélo de Grão}

Complementando o estudo que está realizado, mediu-se o tamanho dos grãos das amostras da liga de alumínio 6063, devidamente 
tratadas, preparada metalograficamente e registrada através da câmera digital acoplada ao Microscópio Óptico. Utilizou-se o método do intercepto linear médio L[28], que representa a média das diagonais entre contomos de grão, de uma deteminada amostra.

Realizaram-se estas medidas de grãos nos diferentes tipos de amostras de acordo com a redução em área (20\%,50\%,70\% e 90\%), posteriores temperaturas de tratamento (396으, $462^{\circ} \mathrm{C}$ e $528^{\circ} \mathrm{C}$ ), e diferentes tempos de tratamento pré-estabelecidos (1minuto, 10 minutos e 100 minutos).

Em cada uma das imagens obtidas por M.O., foram realizadas medições em, praticamente, todos os grãos pertencentes à referida amostra, obtendo-se o tamanho médio de grãos para cada amostra.

\subsection{Preparação das amostras para Microscopia Eetrônica de Transmissão}

Foram preparadas inicialmente amostras da liga de alumínio comercial 6063, lamina das trata das temica mente para a observação em mic roscópio eletrônico de transmissão. Os procedimentos e téc nic as estão descritos a seguir:

1) Corte de discos de $3 \mathrm{~mm}$ de diâmetro de diversas regiões das diversa samostras;

2) Cuidadosa redução da espessura por desbaste mecânico em lixa 600 de granulometria;

3) Polimento eletrolítico automático;

A técnic a utilizada para a preparação das amostras consiste em cortes por eletroerosão, discos de $3 \mathrm{~mm}$ de diâmetro no equipamento disponível no laboratónio de preparação de amostras para MET pertencente ao Departamento de Engenharia de Materiais/IPEN.

Após o corte, a a mostra foi desbastada, com lixa 600, de forma a reduzir a sua espessura a algumas centenas de micrômetros, teminando 
com o polimento eletrolítico automático de jato tipo Tenupol (Struers). O objetivo principal é a redução da espessura da região central, e o a finamento deve prosseguir até a perfuração, criando assim, áreas muito finas ao redor do furo, então a amostra é retirada e submetida ao processo de limpeza.

As amostras, preparadas, foram observadas, analisadas e documentadas em mic roscópio eletrônico de transmissão, J EOL J EM200C, e está disponível no Laboratónio de Microscopia Eletrônica de Transmissão do Departamento de Engenharia de Materia is/IPEN. 
7. - Resultados e Discussões

\section{1 - ANÁUSE QUÚMICA}

Na tabela 6, é mostrada a composição química da a mostra da liga Al-6063, em estudo, realizado pelo CQMA/IPEN - Técnica analítica: Espectrometria de Fluorescência de Raios-X (WDXRF).

Tabela 6 - Composição químic a da liga de alumínio 6063

\begin{tabular}{cccccccccc}
\hline $\begin{array}{c}\text { Elemento } \\
\text { Químico }\end{array}$ & $\mathrm{Si}$ & $\mathbf{M g}$ & $\mathrm{Fe}$ & $\mathrm{Mn}$ & $\mathrm{Cu}$ & $\mathrm{Ni}$ & $\mathrm{Zn}$ & $\mathrm{Cr}$ & $\mathrm{Ti}$ \\
\hline$\%$ & 0,47 & 0,54 & 0,17 & 0,05 & 0,02 & $<0,01$ & $<0,01$ & $<0,01$ & $<0,01$ \\
\hline
\end{tabular}

Em comparação com a tabela 3, padrão para a liga de alumínio 6063[5], nota-se que os elementos de liga em maior concentração, ou seja, Silício (Si) e Magnésio ( $\mathrm{Mg}$ ) apresentam-se com valores superiores ao divulgado na tabela padrão. Quanto ao Ferro (Fe), que é a impureza mais significativa e comum, observou-se que está em um percentual inferior, $0,17 \%$, ao indicado na tabela padrão, $0,35 \%$. Observam-se valores pouco significativos para as outras impurezas encontradas na referida liga.

\section{2 - DFormaÇão PLÁSIICA - LAMINAÇÃo}

O processamento mecânico, ou deformação plástica a frio realizado (redução em área) nos tarugos da amostra da liga de alumínio 6063 estão a presentados na Tabela 7.

Tabela 7 - Proc essa mento Mecânico - La mina ção a frio

\begin{tabular}{lllll}
\hline Redução em área & $20 \%$ & $50 \%$ & $70 \%$ & $90 \%$ \\
\hline
\end{tabular}




\begin{tabular}{ccccc}
\hline $\begin{array}{c}\text { Área Inicial }\left(\times 10^{-}\right. \\
\left.5 \mathrm{~m}^{2}\right)\end{array}$ & 3,19 & 3,23 & 3,20 & 3,12 \\
\hline Área Final $\left(\times 10^{-5} \mathrm{~m}^{2}\right)$ & $2,54 \pm 0,02$ & $1,61 \pm 0,05$ & $0,97 \pm 0,07$ & $0,32 \pm 0,02$ \\
\hline
\end{tabular}

\section{3 - MicrosCOPIA ÓPICA (M.O.)}

As micrografias obtidas por meio da Microscopia Óptica mostram os estudos rea liza dos nas a mostras da liga de a lumínio 6063, com deformação plástica (redução em área) em $20 \%, 50 \%, 70 \%$ e de $90 \%$, temperaturas de tratamento de $396{ }^{\circ} \mathrm{C}, 462^{\circ} \mathrm{C}$ e $528^{\circ} \mathrm{C}$, tempos de tra ta mento estabelecidos em 1minuto, 10 minutos e 100 minutos e a taque químic o, com solução de ácido fluorídrico ( $40 \%$ HF diluído em água ), com tempo médio de aproximadamente de 60s, conforme descrito anteriomente.

Foram registradas para cada deformação plástica, isto é, $20 \%$, $50 \%, 70 \%$ e $90 \%$, com as temperaturas de recozimento e tempos mencionados, as mic rografias a seguir:

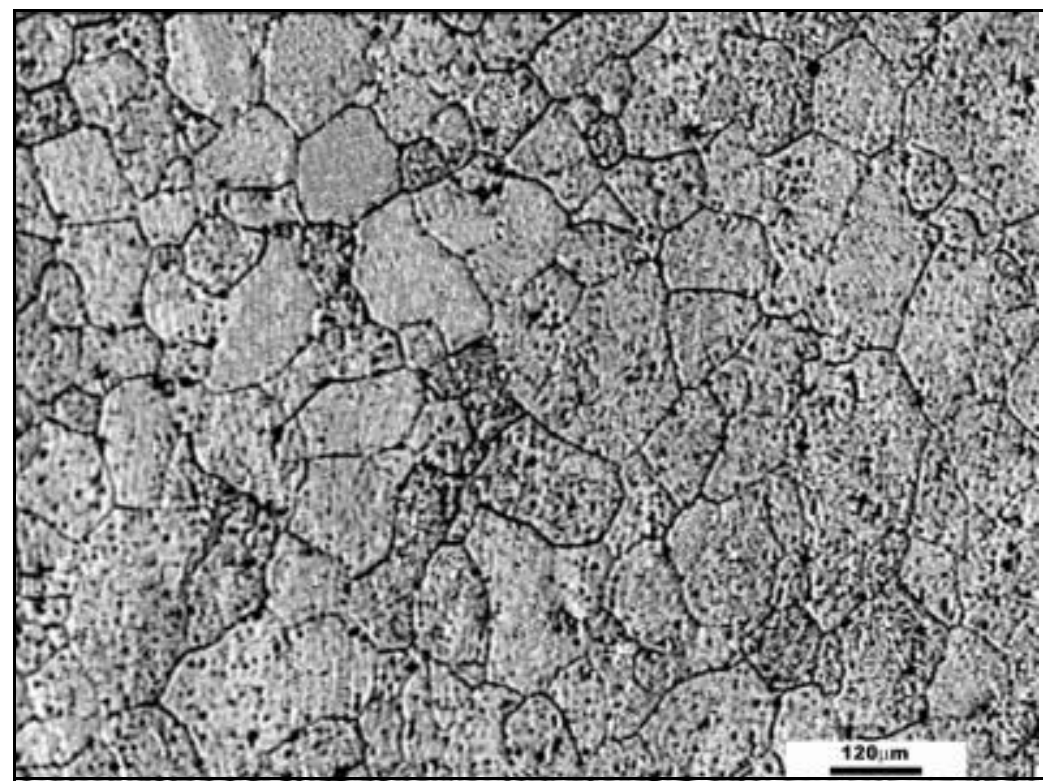

Figura 14. Liga de Al6063 - como rec ebido. 
A figura 14 representa a amostra de alumínio 6063 sem qualquer tipo de tratamento termomecânico.

\subsection{1 - LGA DE ALMÍNIO 6063 - 20\% DE R⿴囗UCCÃO EM ÁREA}
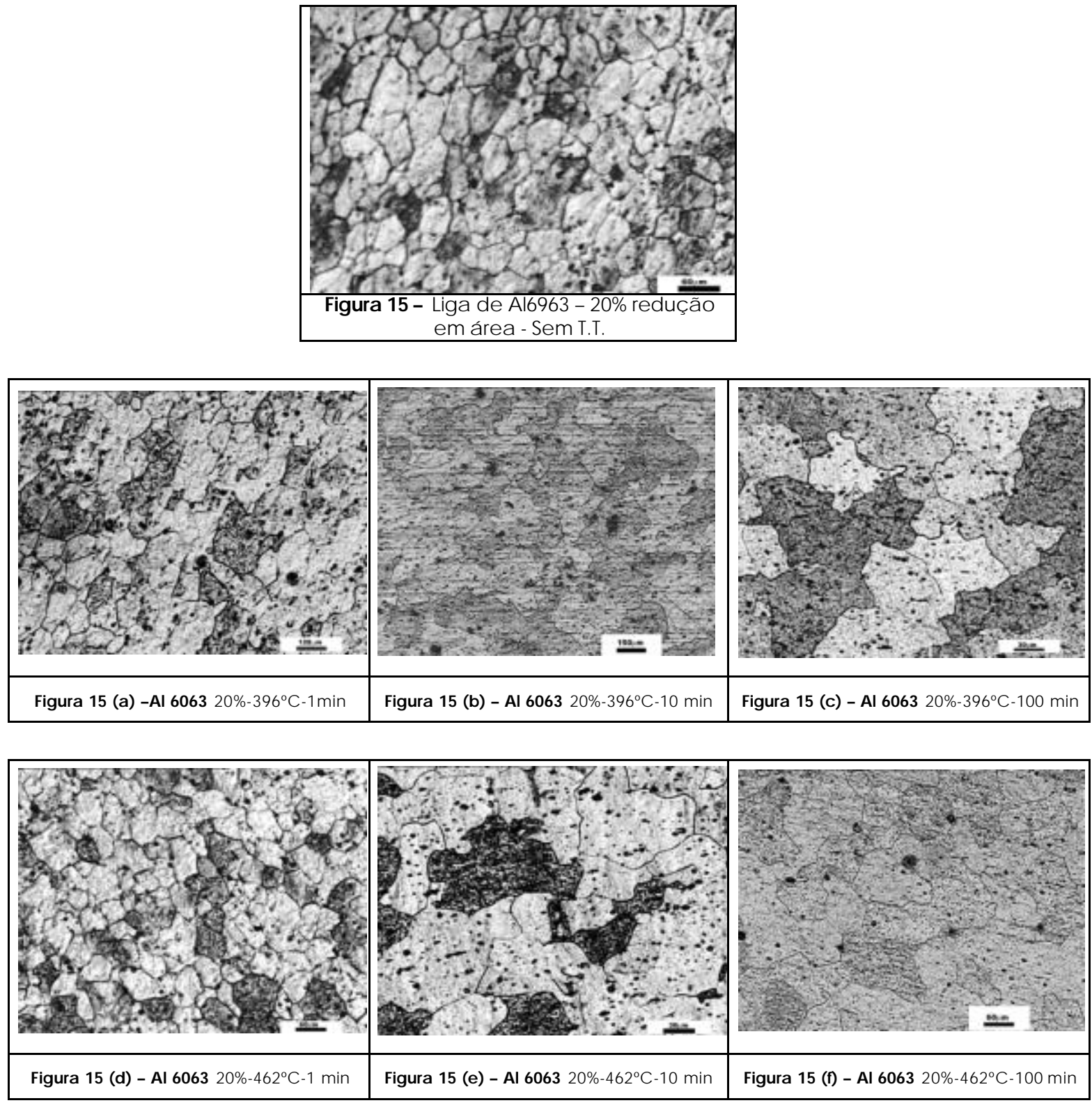


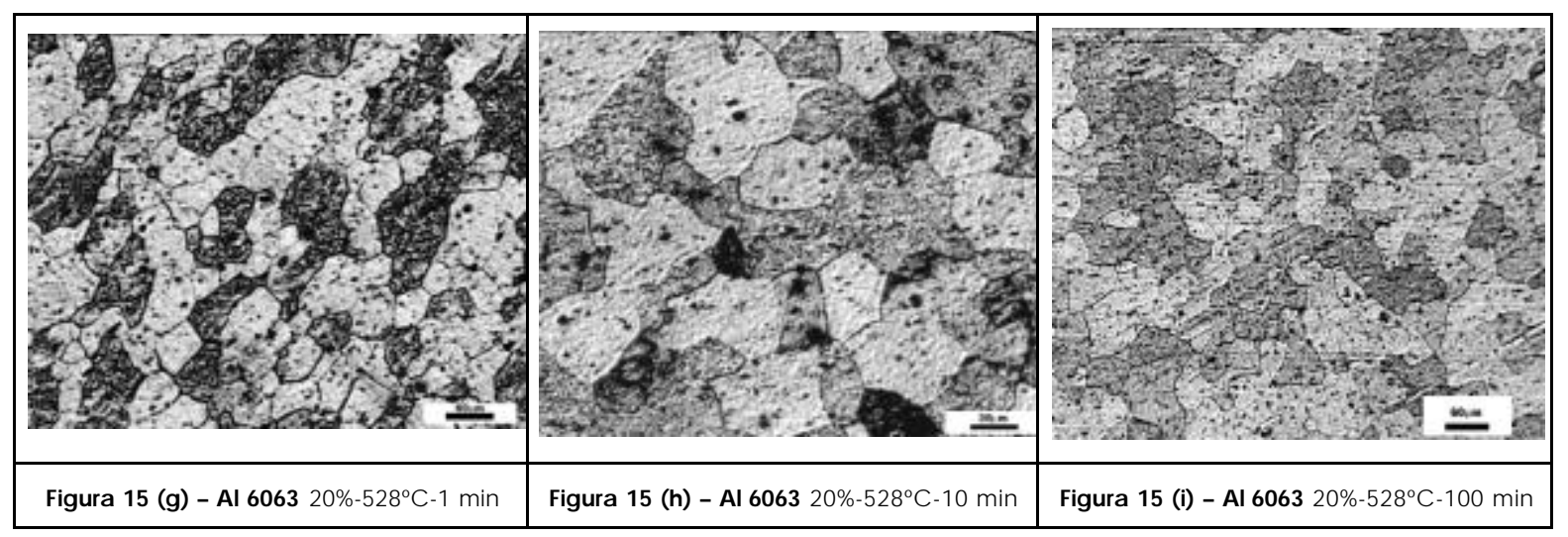

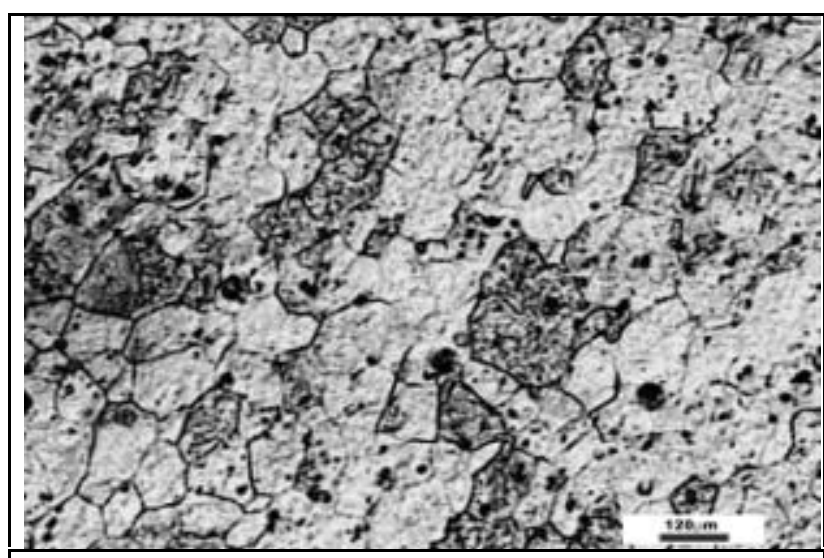

Figura 15 (a) - Al6063 - 20\%-396C - 1 min

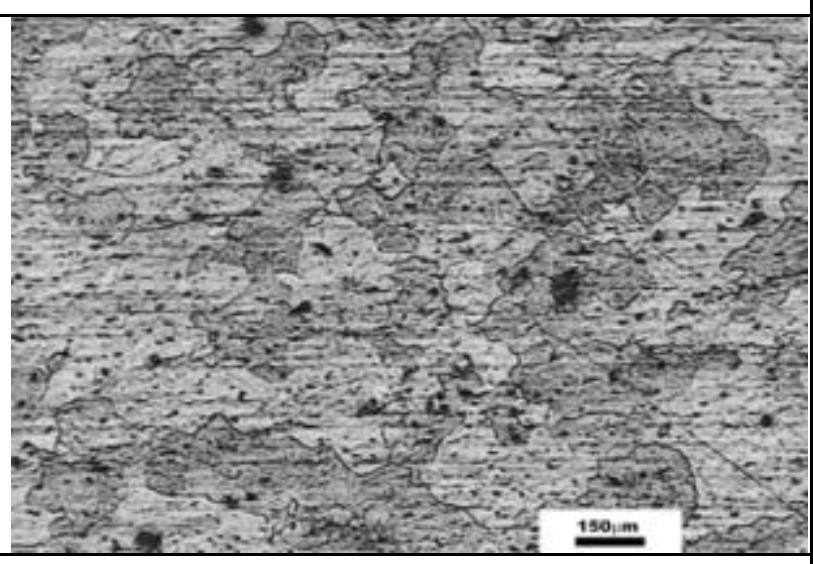

Figura 15 (b) - Al6063 20\%-396ㄷ -10min

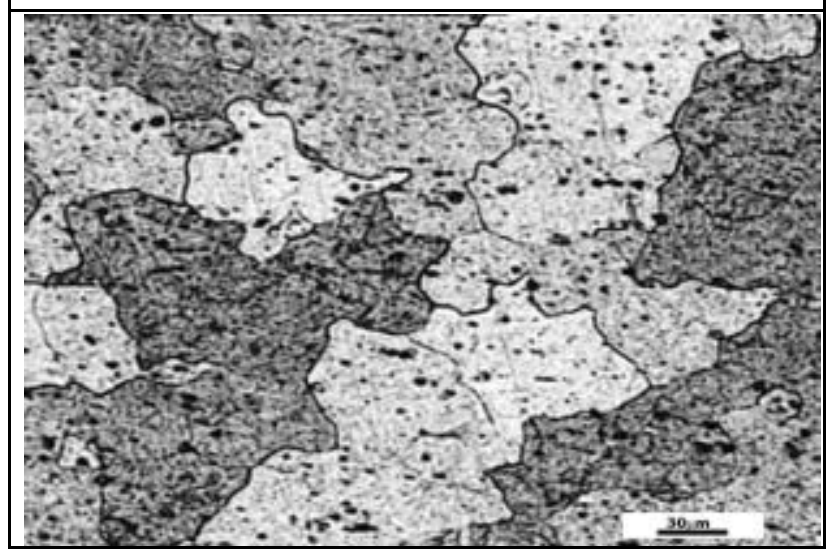

Figura 15 (c) - Al6063 20\%-396ㄷ -

$100 \mathrm{~min}$
Micrografias da liga de alumínio comercial 6063, com deformação plástica de 20\%, tratamento témico em $3960 \mathrm{C}$ e tempos de tratamento de 1minuto, 10 minutose 100 minutos.

Inicialmente, na figura 15(a), com o tempo de tratamento em 1 minuto, e temperatura a 396ㄷ , observa-se a formação / distribuição de grãos na área da amostra. Sendo a maioria dos grãos bem definidos, pouca deformação plástica, com uma certa quantidade de grãos alongados, no sentido da 
laminação, que são característicos dos materia is laminados.

Em 15(b), com o tempo de tratamento em 10 minutos, e temperatura a $396 \circ \mathrm{C}$, observa-se grãos equiaxiais, indicando andamento do processo de recrista liza ção da liga em estudo.

Em 15(c), com o tempo de tratamento em 100 minutos, e temperatura a $396 \circ \mathrm{C}$, com o a umento da temperatura observa-se um discreto aumento no tamanho dosgrãos.

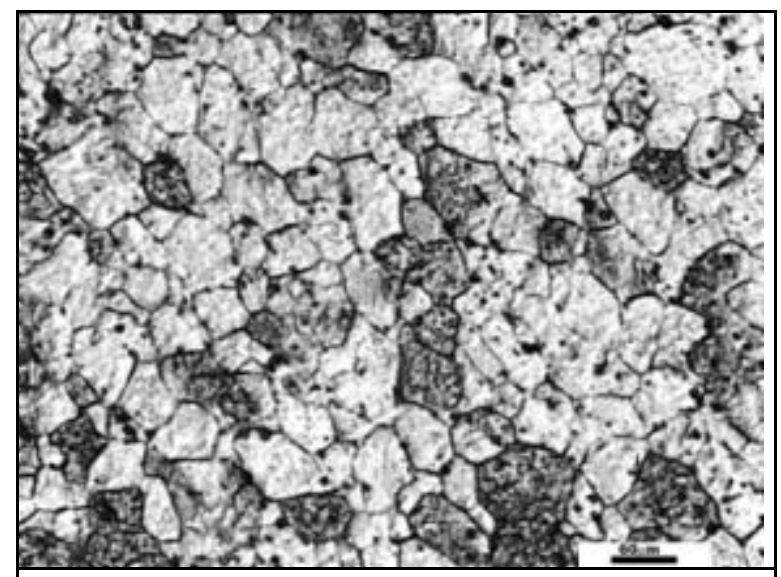

Figura 15 (d) - Al 6063 - 20\%-462으 - 1 min

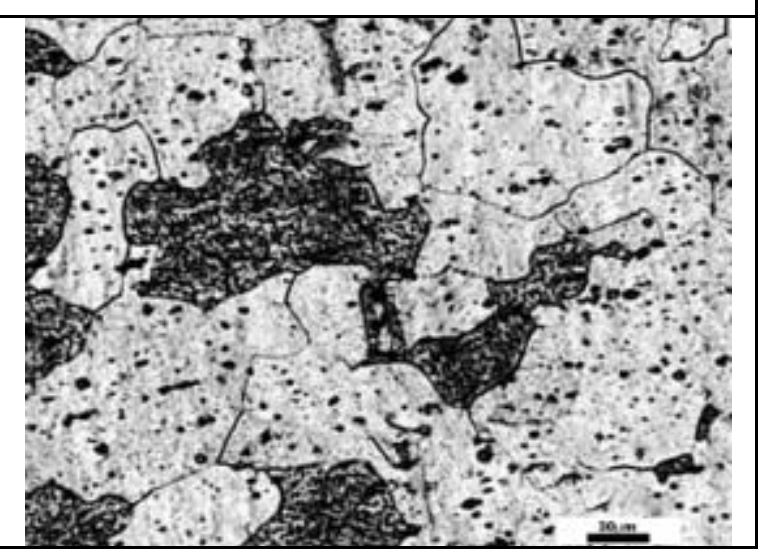

Micrografias da liga de alumínio comercial 6063, com deformação plástica de $20 \%$, tratamento térmico em $462^{\circ} \mathrm{C}$ e tempos de tratamento de 1minuto, 10 minutose 100 minutos.

Com a temperatura ma is elevada os grãos da amostra da liga de alumínio 6063, têm grãos bem definidos.

Na figura 15(d), com o tempo de tratamento em 1 minuto, e temperatura a $4622^{\circ} \mathrm{C}$ de recozimento, indica o processo de recuperação/ recristalização 
avançado, pois os grãos estão em formatos equiaxia is.

Observa-se na figura 15(e), com o tempo de tratamento em 10 minutos, e temperatura a 462으, finalizado o processo de recuperação, o processo de recristalização está com indícios de crescimento de grãos. $E$, na figura 15(f), com o tempo de tratamento em 100 minutos, e temperatura a $462^{\circ} \mathrm{C}$, o processo de crescimento de grãos evidencia-se.

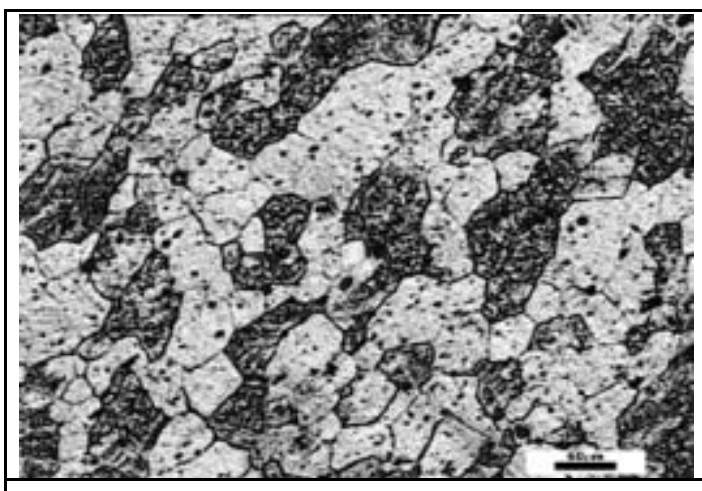

Figura 15 (g) - Al 6063 - 20\%-528ㄷ - $1 \mathrm{~min}$

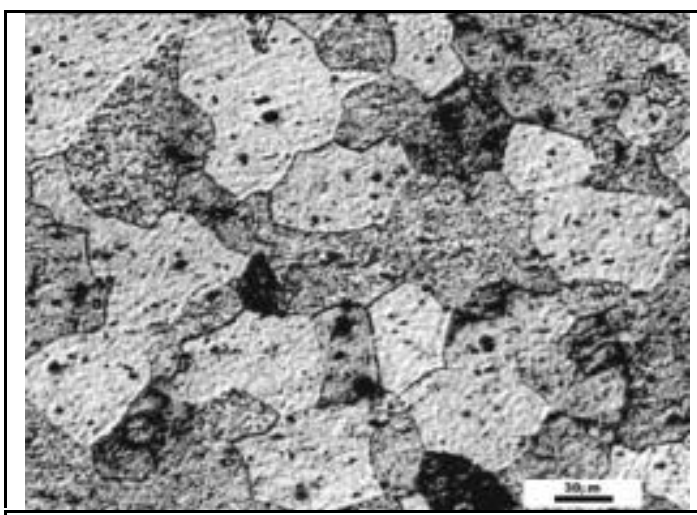

Figura 15 (h) - Al6063 - 20\%-528ㄷ -

$10 \mathrm{~min}$

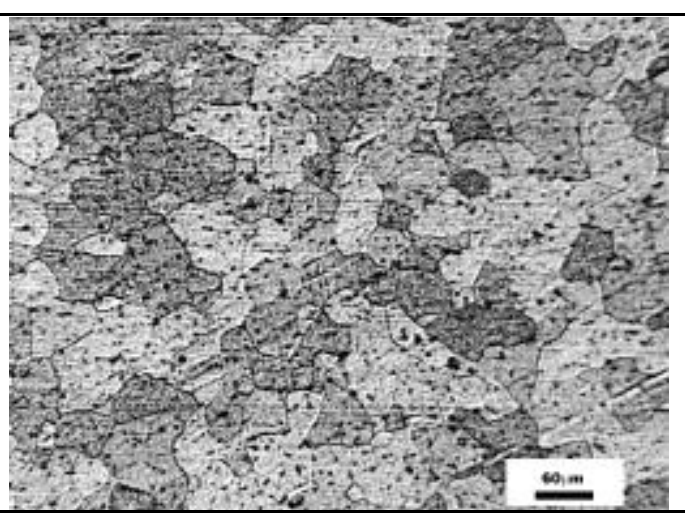

Figura 15 (i) - Al6063 - 20\%-528ㄷ C -

$100 \mathrm{~min}$

Micrografias da liga de alumínio comercial 6063, com deformação plástica de $20 \%$, tratamento témico em $528^{\circ} \mathrm{C}$ e 
tempos de tratamento de 1minuto, 10 minutose 100 minutos.

Com a temperatura ma is elevada os grãos da amostra da liga de alumínio 6063, têm grãos com formato equiaxial.

Na figura $15(\mathrm{~g})$, com o tempo de tratamento em 1 minuto, e temperatura a $528^{\circ} \mathrm{C}$ de recozimento, indica o processo de recuperação/ recristalização bastante avançado.

Observa-se na figura 15(h), com o tempo de tratamento em 10 minutos, e temperatura a
528드, completa do o processo de recuperação, o processo de recrista lização está com indícios de crescimento de grãos. $E$, na figura 15(i), com o tempo de tratamento em 100 minutos, e temperatura a $528^{\circ} \mathrm{C}$, o processo de crescimento de grãos evidencia-se.

\subsection{2 - LGA DE ALUMÍNIO 6063 - 50\% DE REDUÇÃO EM ÁREA}
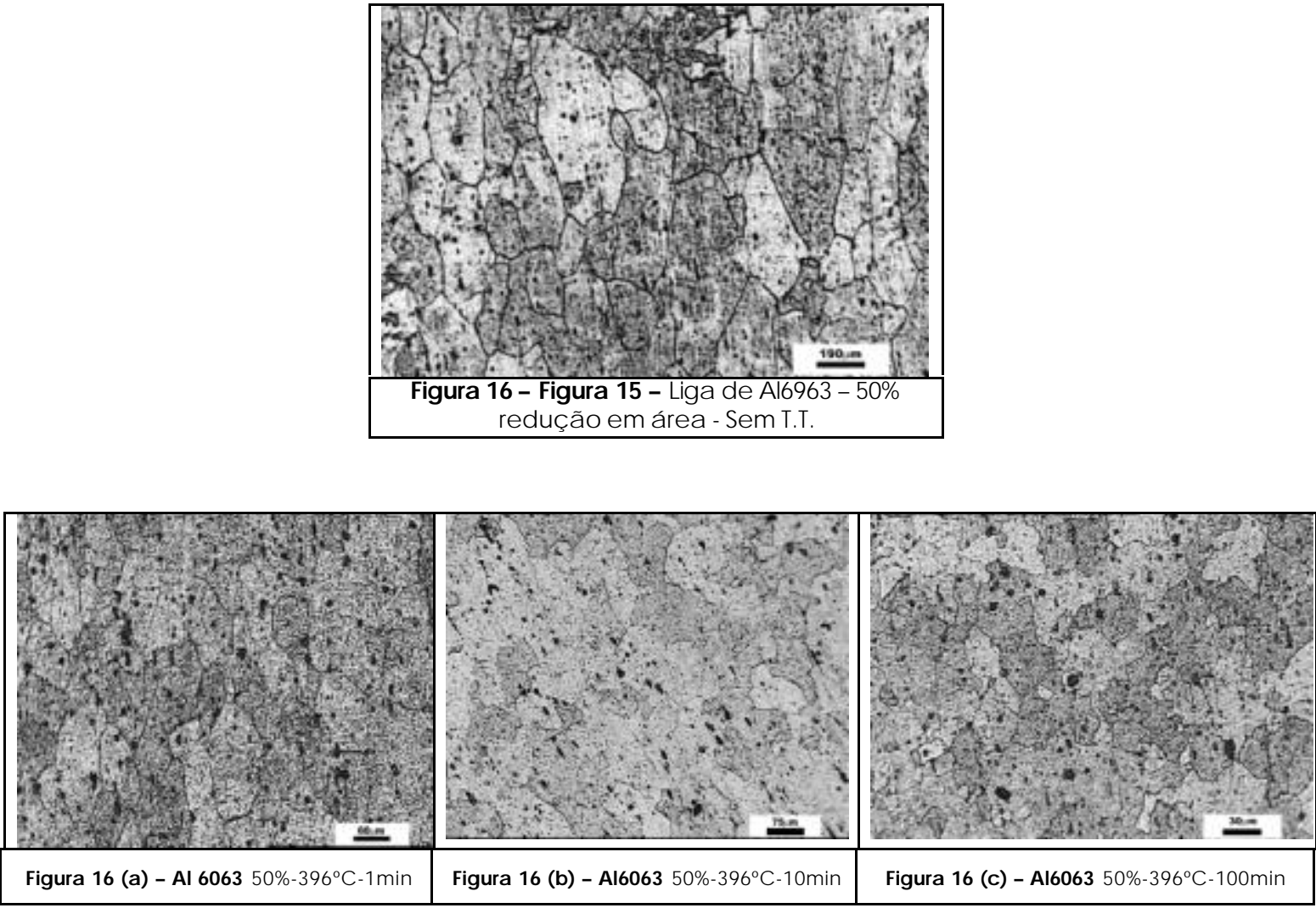

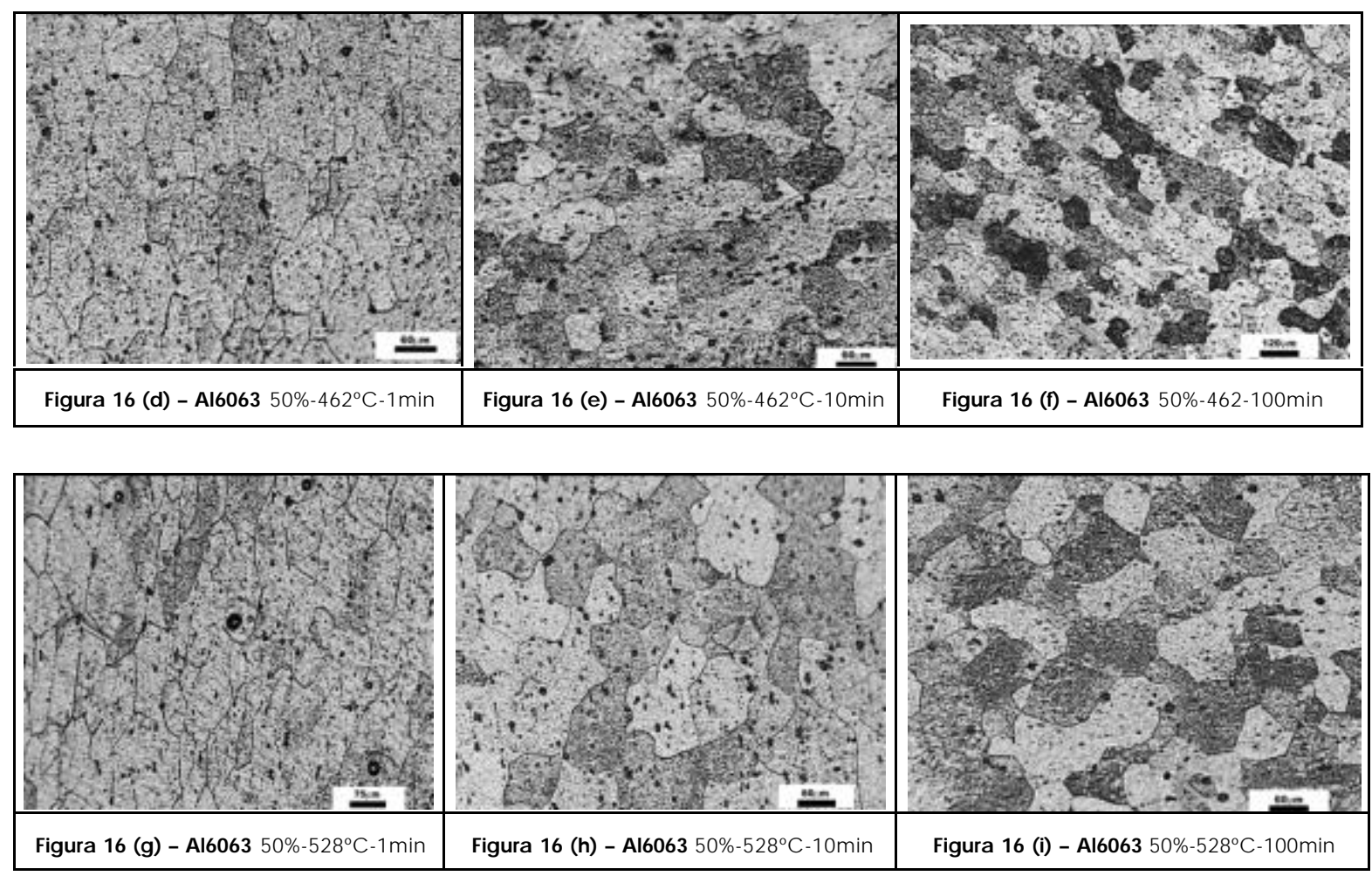

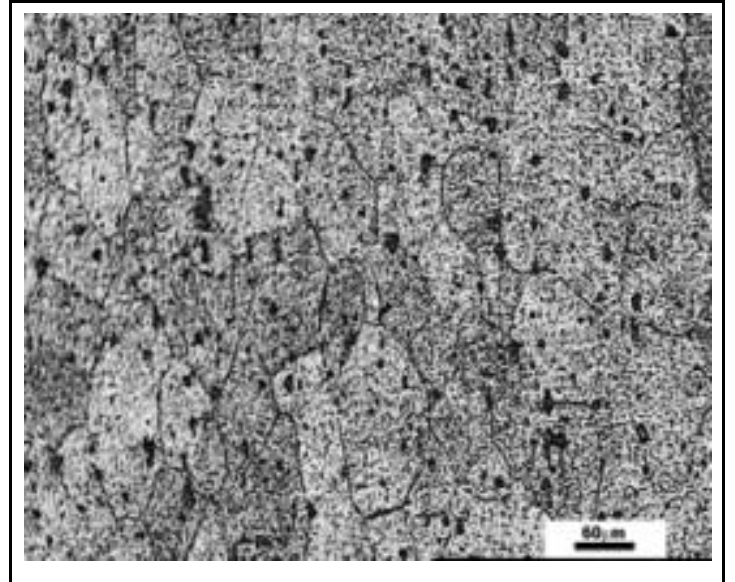

Figura 16 (a) - Al6063 - 50\%-396ㄷ - 1 min

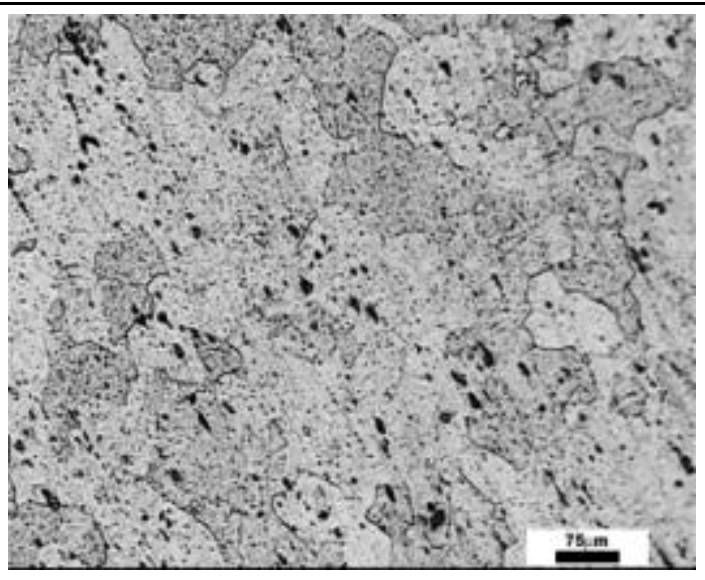

Figura 16 (b) - Al6063 50\%-396ㄷ - $10 \mathrm{~min}$

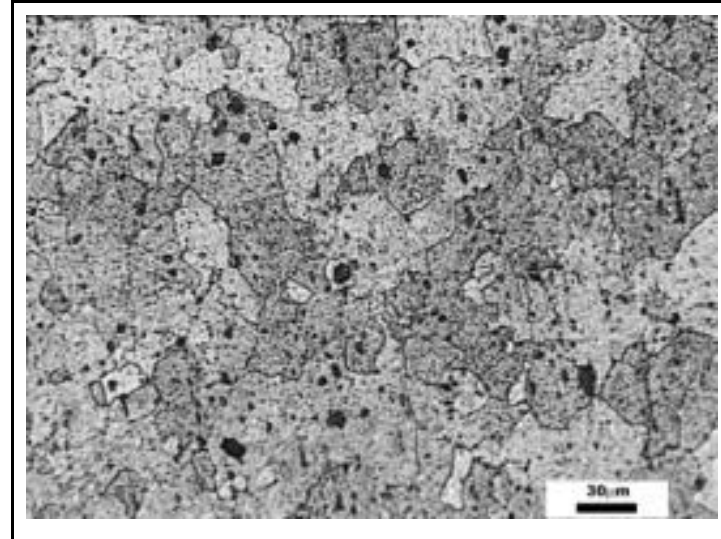

Figura 16 (c) - Al6063 50\%-396ㄷ -100min

Micrografias da liga de alumínio comercial 6063, com deformação plástica de 50\%, 
tratamento térmico em 396 oc e tempos de tratamento de 1minuto, 10 minutose 100 minutos.

Na figura $16(a)$, com o tempo de tratamento em 1 minuto, e temperatura a $396 \circ \mathrm{C}$ de recozimento, indicam grãos alongados justificados pelo estado laminado da amostra da liga de a lumínio 6063.

Observa-se na figura 16(b), com o tempo de tratamento em 10 minutos, e temperatura a 3960 C, apresenta grãos ma is regulares caracterizando 0 andamento do processo de recuperação/rec rista lização.

A figura 16(c), com o tempo de tratamento em 100 minutos, e temperatura a $396 \% \mathrm{C}$, indica grãos equiaxia is, evidenciando a rec rista liza ção da liga.
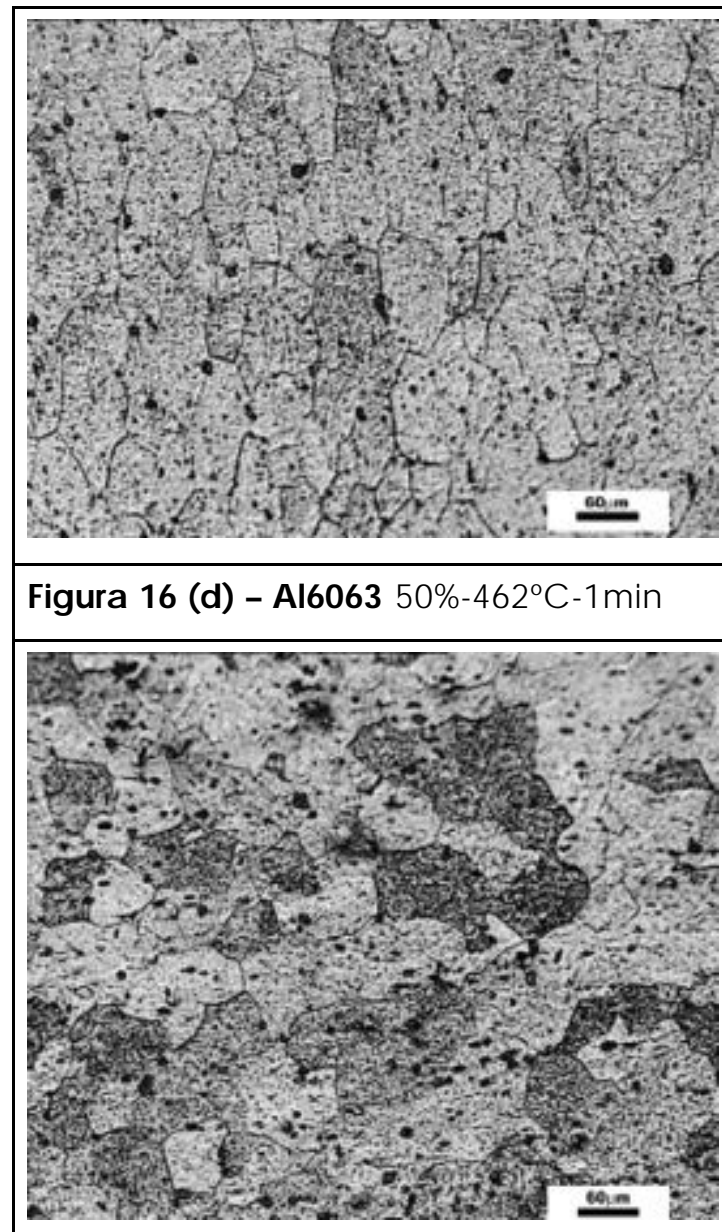

Figura 16 (e) - Al6063 50\%-462ㅇ-10min

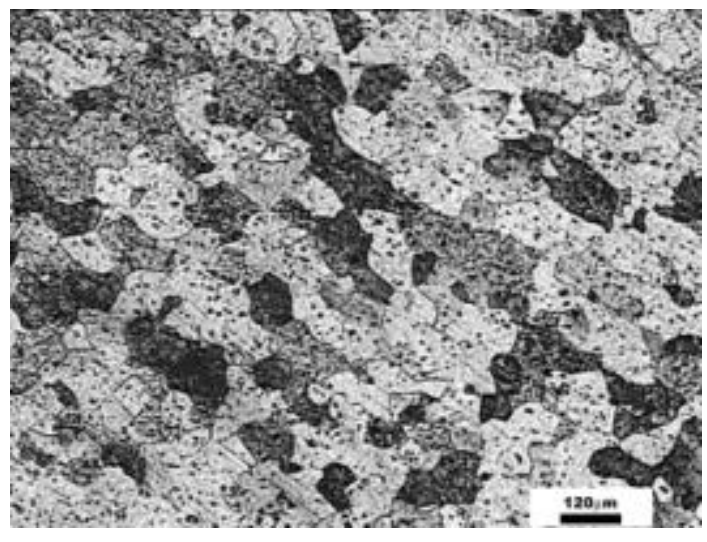

Figura 16 (f) - Al6063 50\%-462-100min 
Na figura $16(d)$, com o tempo de tratamento em 1 minuto, e temperatura a $462^{\circ}{ }^{\circ} \mathrm{C}$ de recozimento, indicam grãos alongados justificados pelo estado laminado da amostra da liga de alumínio 6063.

Observa-se na figura 16(e), com o tempo de tratamento em 10 minutos, e temperatura a $462^{\circ} \mathrm{C}$, a presenta grã os equia xia is caracterizando o andamento do processo de recuperação/rec ristalização.

A figura 16(f), com o tempo de tratamento em 100 minutos, e temperatura a $462^{\circ} \mathrm{C}$, indica grãos equiaxia is, evidenciando a recrista liza ção da liga, observa-se, ta mbém, discreto crescimento de grãos.

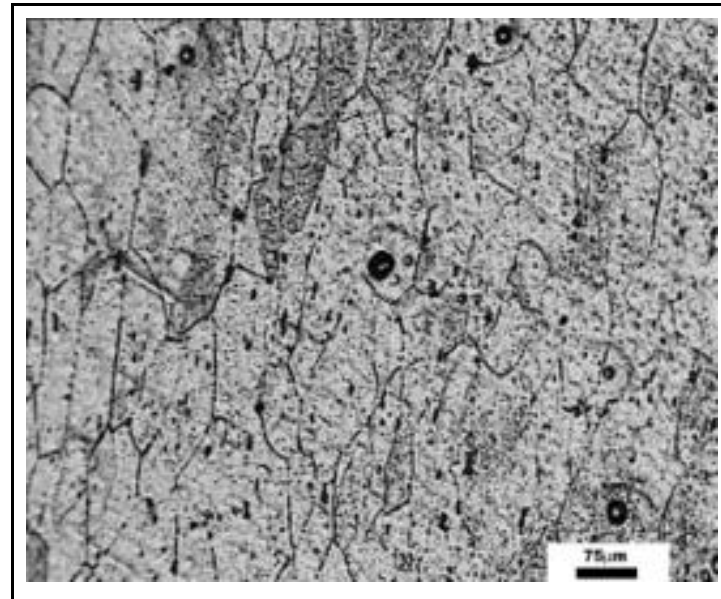

Figura 16 (g) - Al6063 50\%-528ㄷ - 1 min

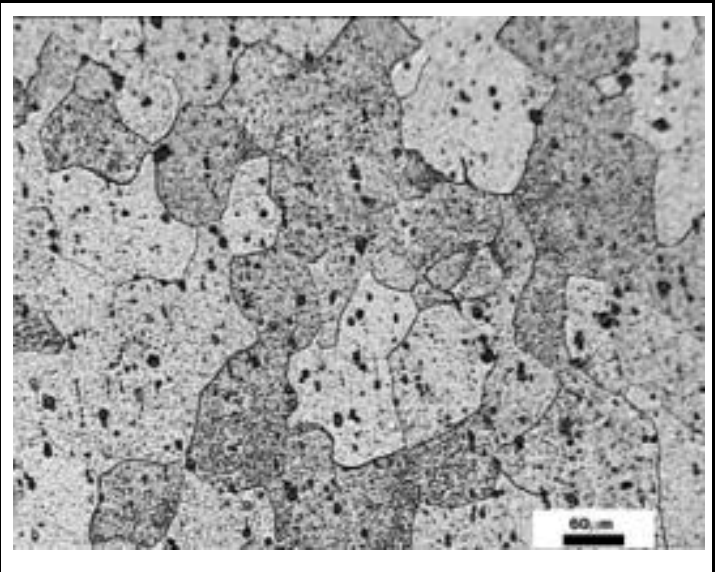

Figura 16 (h) - Al6063 50\%-528ㄷ -10min

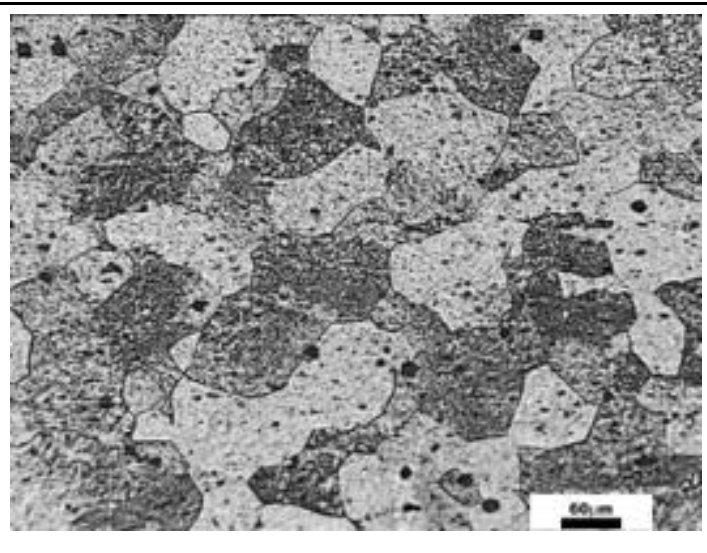

Figura 16 (i) - Al6063 50\%-528ㄷ -100min 
Para as amostras da liga de alumínio 6063, com 50\% de redução em área e tratamentos térmic os a $528^{\circ} \mathrm{C}$, as observações realizadas nas seqüências anteriores, com tratamentos térmicos de $396^{\circ} \mathrm{C}$ e $462^{\circ} \mathrm{C}$, podem comparar as tendências que ind ic a m asfiguras:

Figura 16 (g): formação de grãos não equiaxia is (alongados), que se justifica pelo estado laminado da amostra da liga de alumínio 6063, com o tempo de tratamento em 1 minuto.

Figura 16 (h): apresenta uma quantidade significativa de grãos equiaxiais, o que caracteriza o processo

de rec uperação/rec nista liza ção da a mostra em estudo.

Figura 16 (i): com o aumento da temperatura observa-se uma discreta diminuição do tamanho do grão, o que indica que a tendência de crescimento destes grãos está controlada pelo precipitado $\mathrm{Mg}_{2} \mathrm{Si}$, presente na a mostra da liga de alumínio 6063.

\subsection{3 - Liga de alumínio 6063 - 70\% de redução em área}

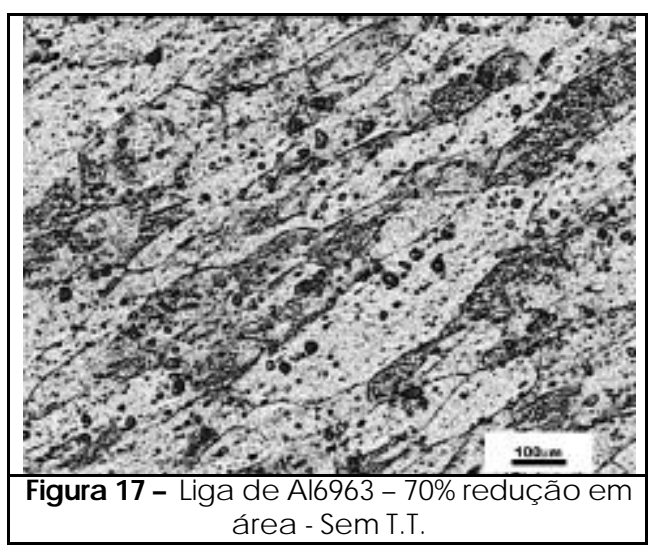



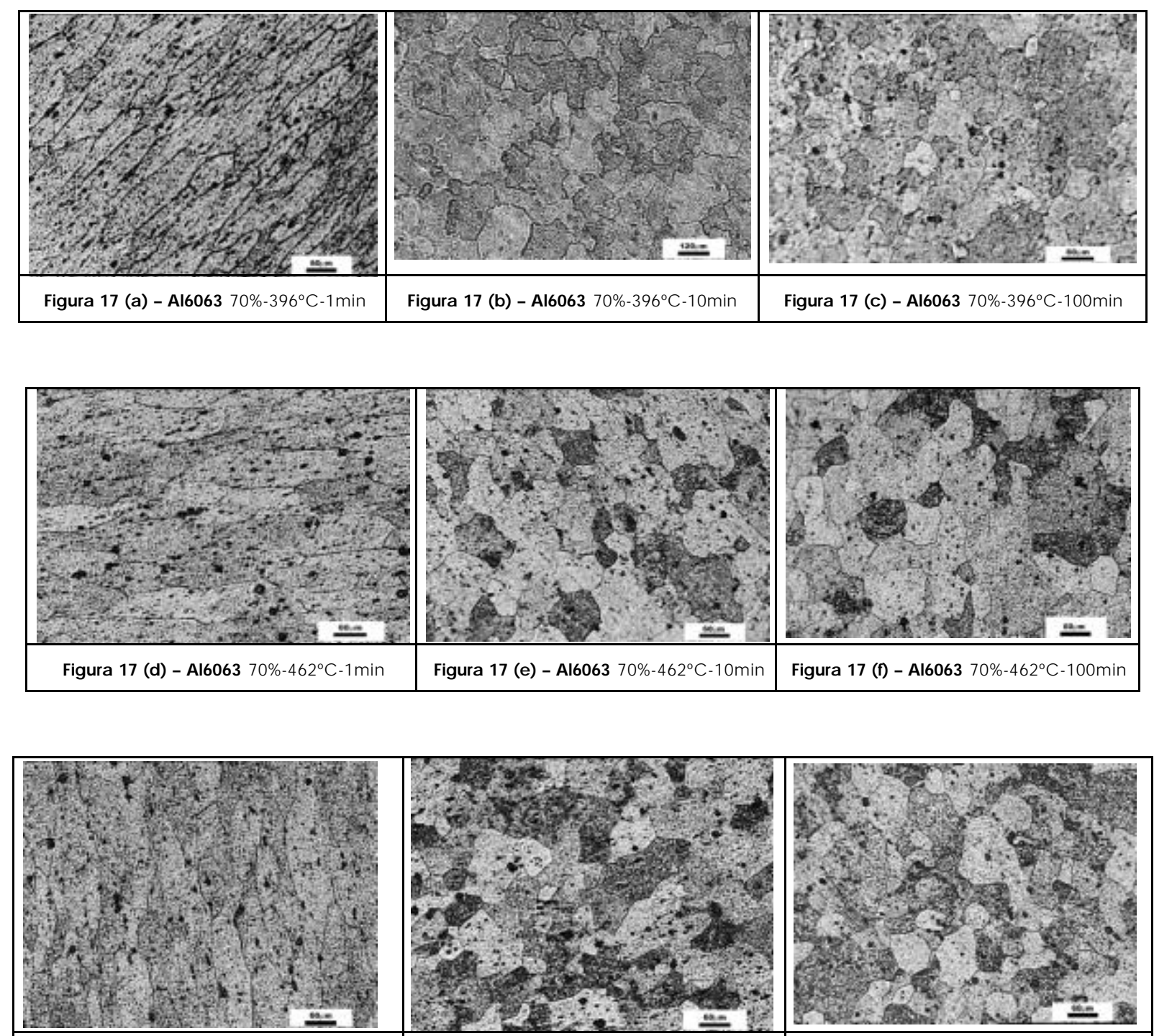

Figura 17 (g) - Al6063 70\%-528ㄷ-1min

Figura 17 (h) - Al6063 70\%-528ㄷ -10min

Figura 17 (i) - Al6063 70\%-528ㄷ-100min
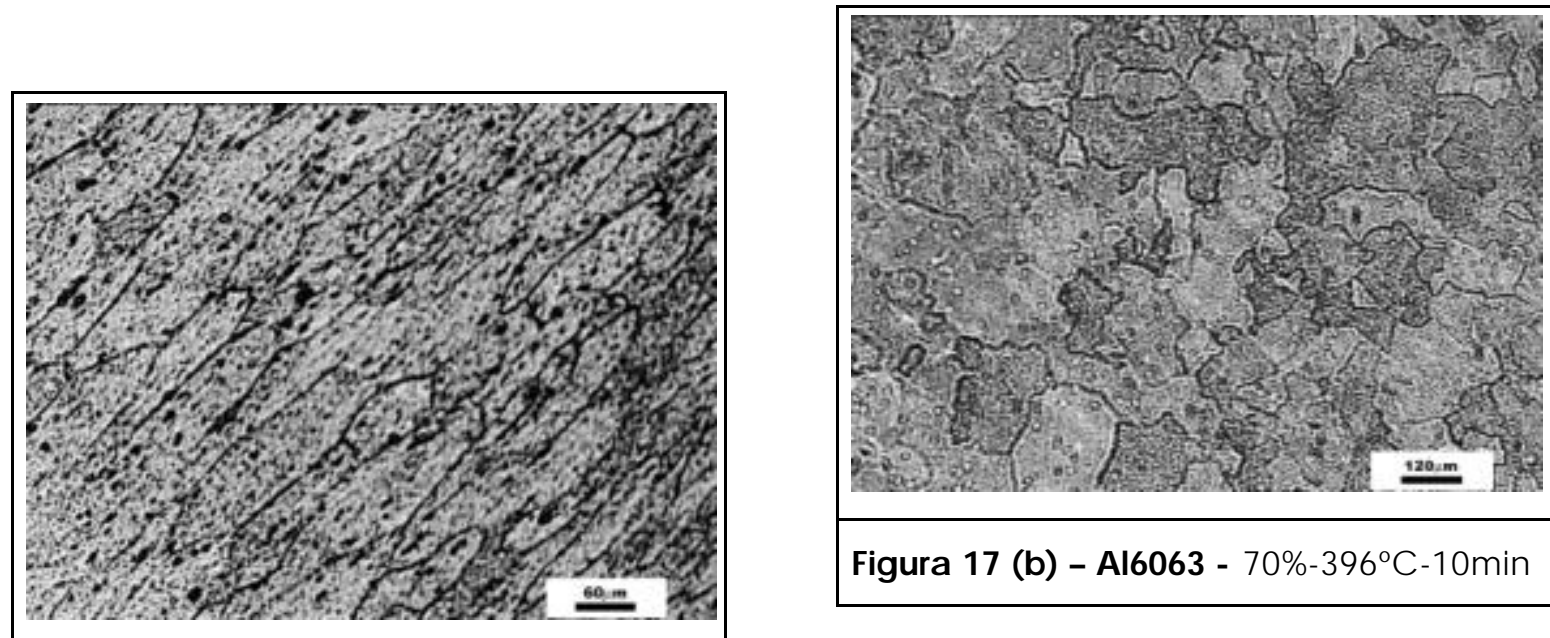

Figura 17 (b) - Al6063 - 70\%-396ㄷ -10min

Figura 17 (a) - Al6063 - 70\%-396ㄷ - 1 min 


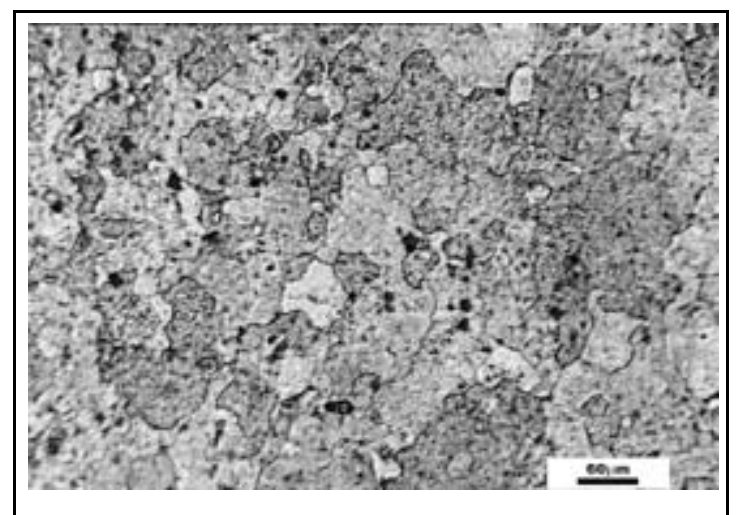

Figura 17 (c) - Al6063 - 70\%-396oC$100 \mathrm{~min}$

10 minutos, e temperatura a 396드, a presenta com tendência regulares, mas ainda alongados devido ao alto grau de deformação plástica sofrido, caracterizando o andamento do processo de recuperação/ rec rista liza ção.

A figura $17(\mathrm{c})$, com o tempo de tratamento em 100 minutos, e temperatura a $396 \circ \mathrm{C}$, indica grãos com formato equiaxial, evidenciando a recrista liza ção da liga.

Micrografias da liga de alumínio comercial 6063, com deformação plástica de 70\%, tratamento térmico em $396 \circ \mathrm{C}$ e tempos de tratamento de 1minuto, 10 minutose 100 minutos.

Na figura $17(a)$, com o tempo de tratamento em 1 minuto, e temperatura a $396 \circ \mathrm{C}$ de recozimento, indicam grãos bastante alongados justificados pelo estado laminado da amostra da liga de alumínio 6063.

Observa-se na figura 17(b), com o tempo de tratamento em

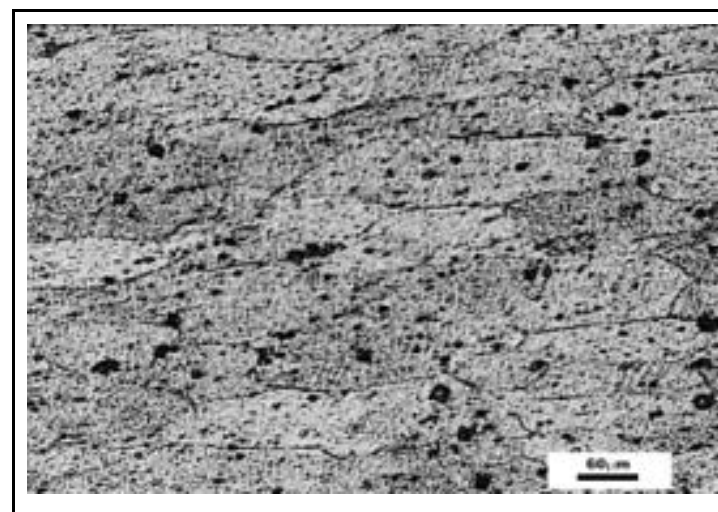

Figura 17 (d) - Al6063 - 70\%-462ㄷ - 1 min

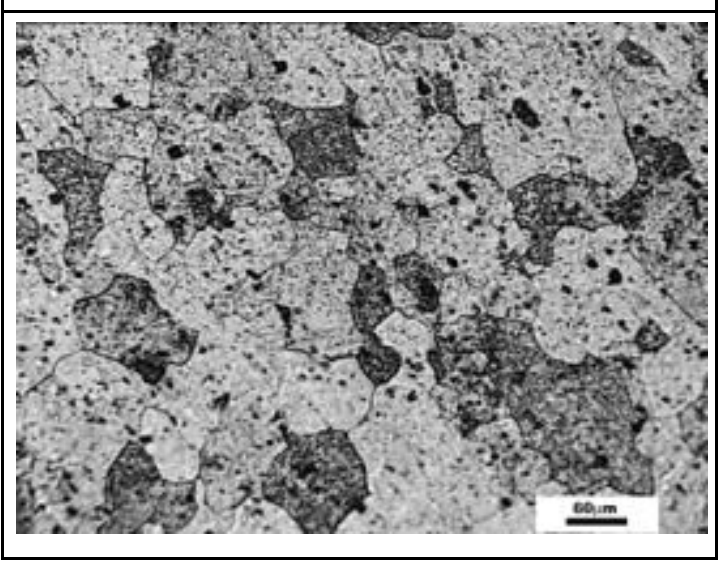




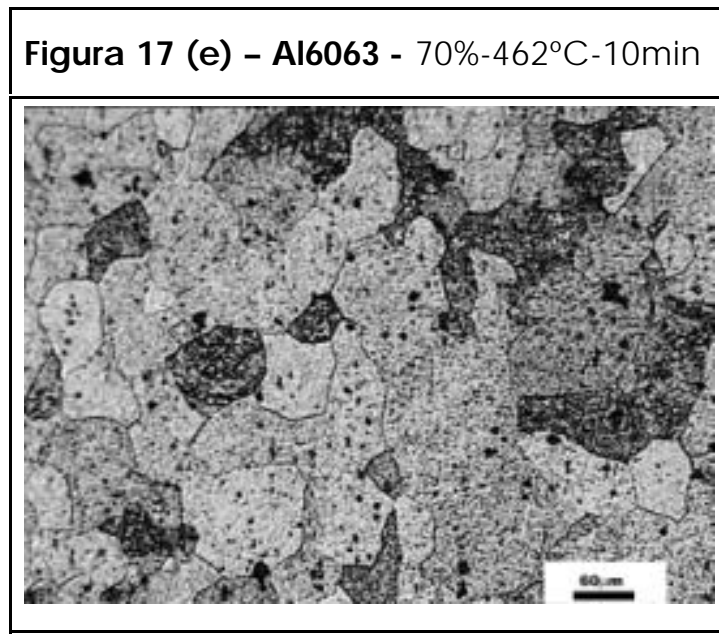

Figura 17 (f) - Al6063 - 70\%-462ㄷ-100min
A figura 17(f), com o tempo de tratamento em 100 minutos, e temperatura a $462^{\circ} \mathrm{C}$, indica grãos equiaxia is, evidenciando a rec rista liza ção da liga, observa-se, também, ligeiro decrescimento dos grãos, devido aos precipitados $\mathrm{Mg}_{2} \mathrm{Si}$, que se formam nesta liga, evitando o c resc imento exc essivo dos grãos.
Na figura $17(d)$, com o tempo de tratamento em 1 minuto, e temperatura a $462^{\circ} \mathrm{C}$ de recozimento, indicam grãos alongados justificados pelo estado laminado da amostra da liga de alumínio 6063.

Observa-se na figura 17(e), com o tempo de tratamento em 10 minutos, e temperatura a $462^{\circ} \mathrm{C}$, a presenta grã os equiaxia is caracterizando o andamento do processo de rec upera ção/rec rista lização.

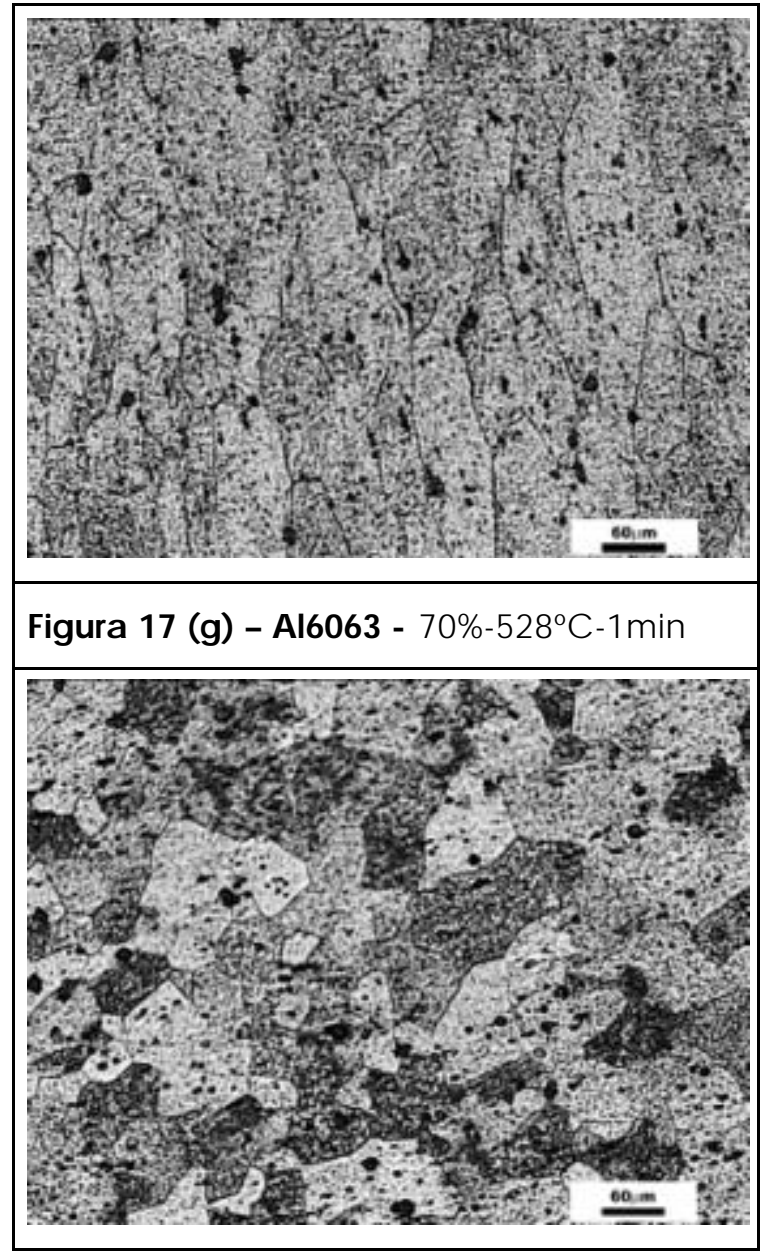




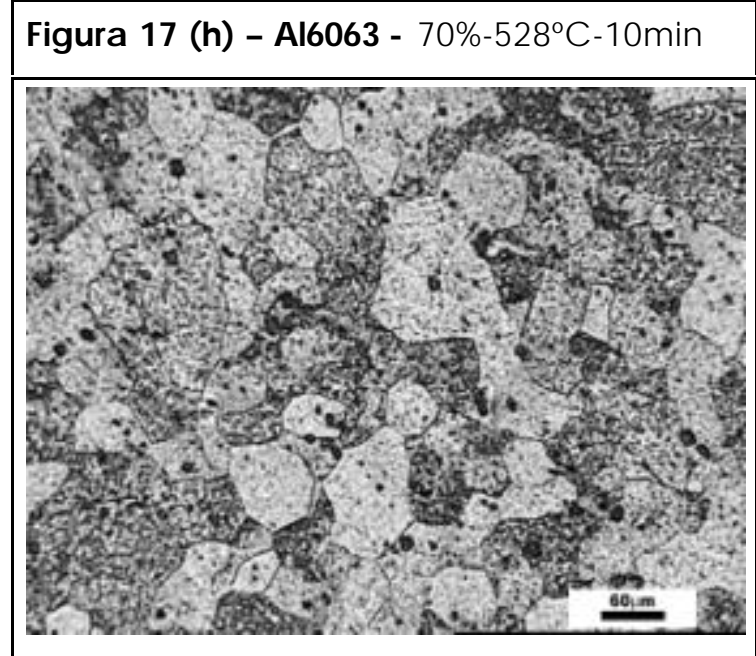

Figura 17 (i) - Al6063 - 70\%-528C -100min
Para as amostras da liga de alumínio 6063, com 70\% de redução em área e tratamentos térmic os a $528^{\circ} \mathrm{C}$, as observações realizadas nas seqüências anteriores, com tratamentos témicos de $396^{\circ} \mathrm{C}$ e $462^{\circ} \mathrm{C}$, podem comparar as tendências que ind ic a m asfiguras:

Figura $17 \quad(\mathrm{~g})$ : Grãos alongados, que se justifica pelo estado laminado da amostra da liga de alumínio 6063, com o tempo de tratamento em 1 minuto.

Figura 17 (h): apresenta uma quantidade signific a tiva de grãos equiaxiais, o que caracteriza o processo de recristalização da a mostra em estudo.

Figura 17 (i): com o aumento da temperatura observa-se um crescimento menos acentuado aos tempos de tratamento anteriores (1 minuto e 10 minutos) no tamanho do grão, causada pelo precipitado $\mathrm{Mg}_{2} \mathrm{Si}$, presente na amostra da liga de alumínio 6063.

\subsection{4 - Liga de alumínio 6063 - 90\% de redução em área}




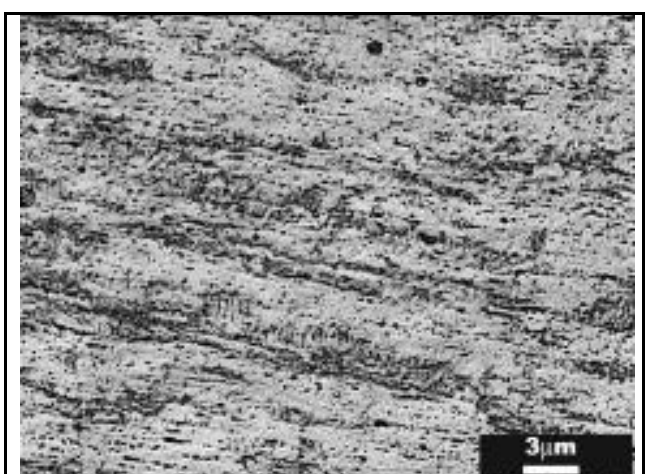

Figura 18- Liga de Al6963 - 90\% redução em área - Sem T.T.
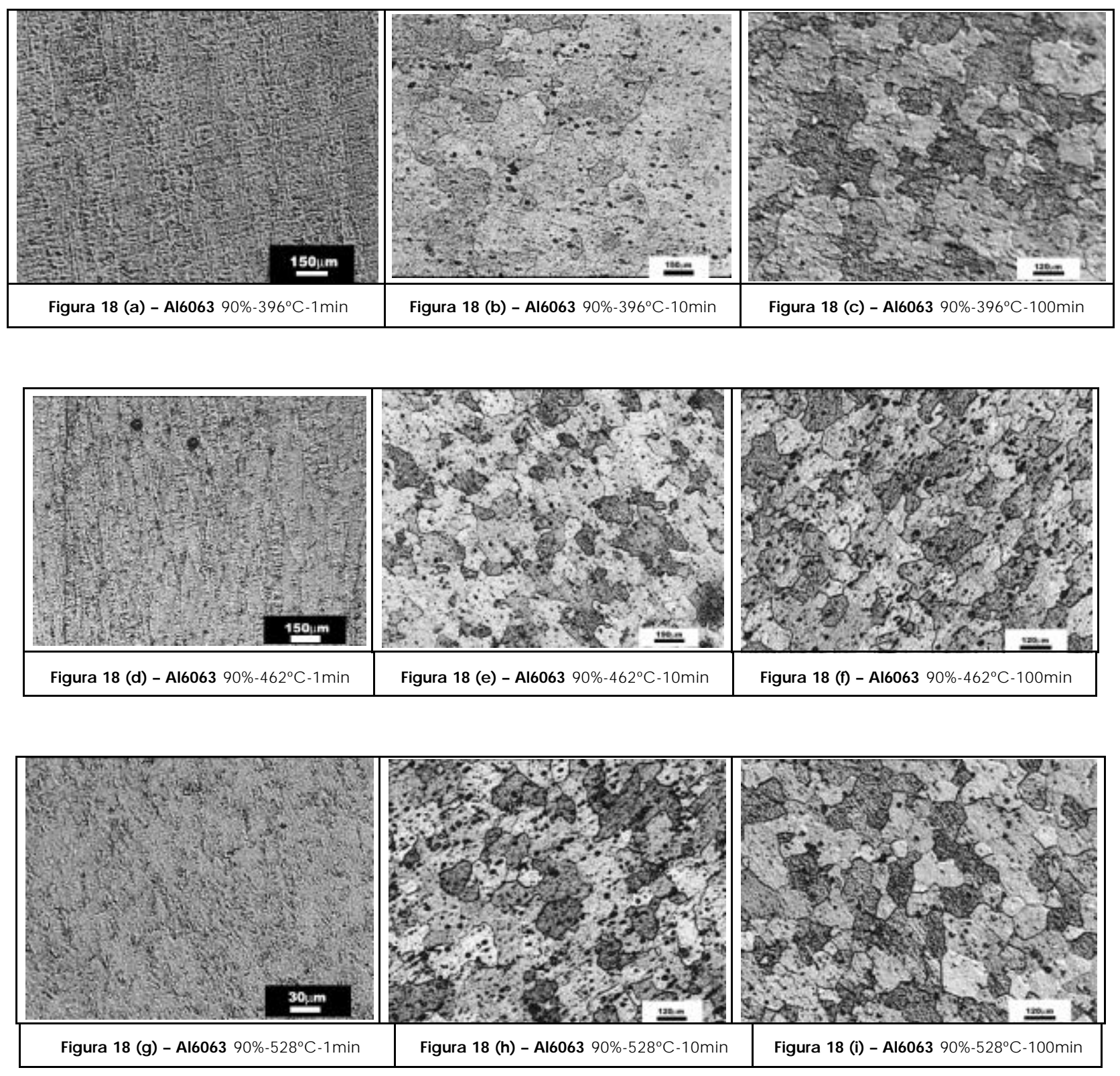


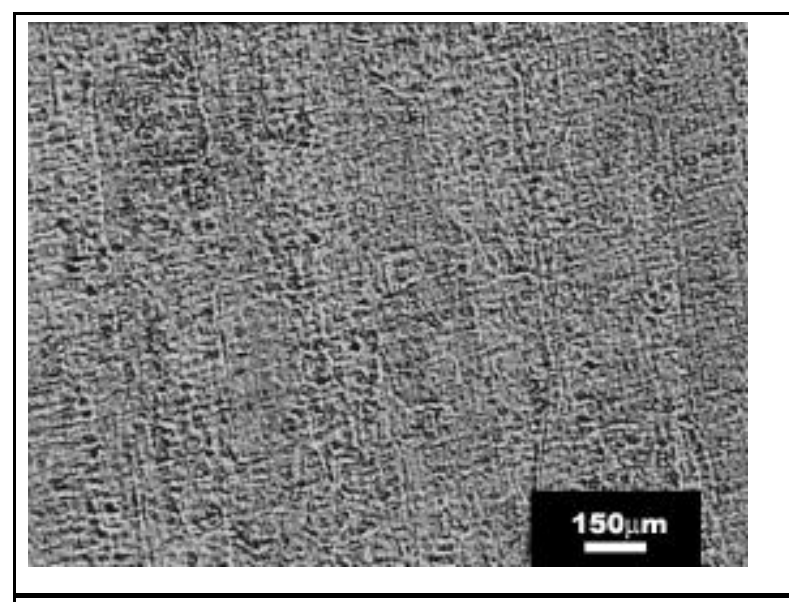

Figura 18 (a) - Al6063 - 90\%-396C-1min

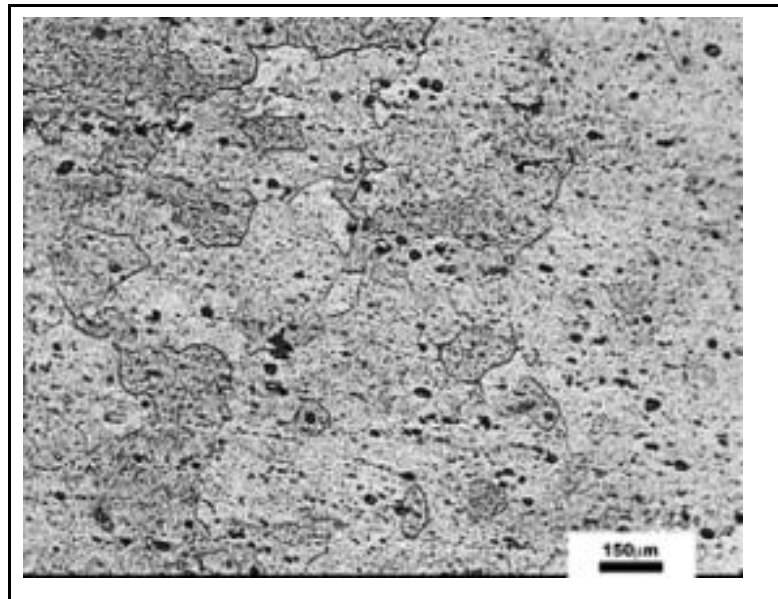

Figura 18 (b) - Al6063 - 90\%-396ㄷ -10min

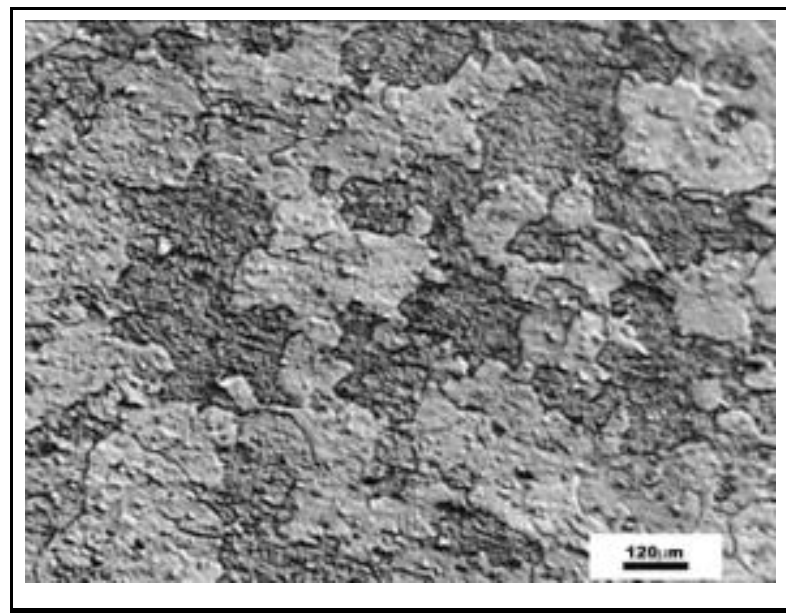

Figura 18 (c) - Al6063 - 90\%-396ㄷ -100min
Micrografias da liga de alumínio comercial 6063, com deformação plástica de 90\%, tratamento térmico em $396 \circ \mathrm{C}$ e tempos de tratamento de 1minuto, 10 minutose 100 minutos.

Na figura 18(a), com o tempo de tratamento em 1 minuto, e temperatura a $3960 \mathrm{C}$ de recozimento, indicam grãos bastante alongados justificados pelo estado lamina do da amostra da liga de alumínio 6063. Embora, a quantidade de energia fomecida à liga pelo excesso de deformação plástica, indica que mesmo antes do tratamento a amostra já estava sofrendo o processo de recuperação.

Observa-se na figura 18(b), com o tempo de tratamento em 10 minutos, e temperatura a 396 드, a presenta com tendência regulares, mas ainda alongados devido ao alto grau de deformação plástica realizado, caracterizando o andamento do processo de recrista liza ção.

A figura 18(c), com o tempo de tratamento em 100 minutos, e temperatura a $396^{\circ} \mathrm{C}$, indica 
grãos com formato equiaxial, evidenciando a recrista lização da liga.

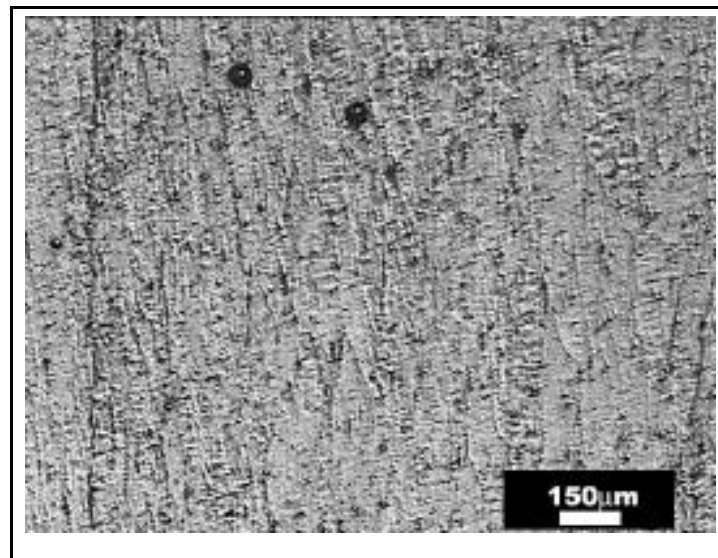

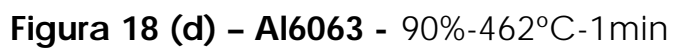

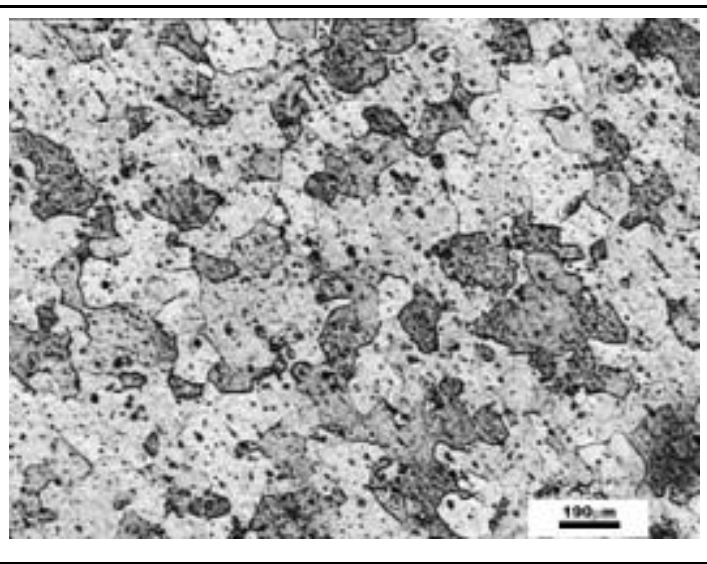

Figura 18 (e) - Al6063 - 90\%-462ㅇ-10min

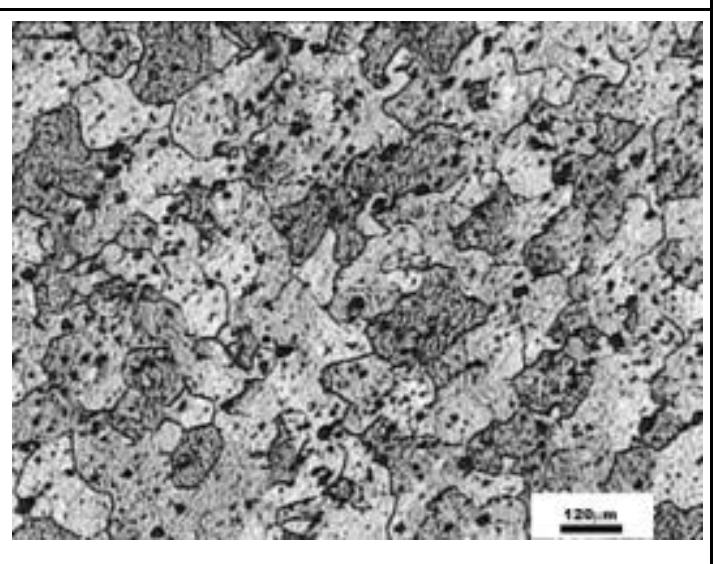

Figura 18 (f) - Al6063 - 90\%-462ำ-100min
Na figura $18(d)$, com o tempo de tratamento em 1 minuto, e temperatura a $4622^{\circ} \mathrm{C}$ de recozimento, indicam grãos a inda alongados justificados pelo estado laminado da amostra da liga de alumínio 6063.

Observa-se na figura 17(e), com o tempo de tratamento em 10 minutos, e temperatura a $462^{\circ} \mathrm{C}$, a presenta grãos equiaxia is caracterizando o andamento do processo de recrista liza ção.

A figura 18(f), com o tempo de tratamento em 100 minutos, e temperatura a $462^{\circ} \mathrm{C}$, indica grãos equiaxia is, evidenciando a rec rista lização da liga, observa-se, também, ligeiro decrescimento dos grãos, devido aos precipitados $\mathrm{Mg}_{2} \mathrm{Si}$, que se formam nesta liga, evitando o cresc imento exc essivo dos grãos. 


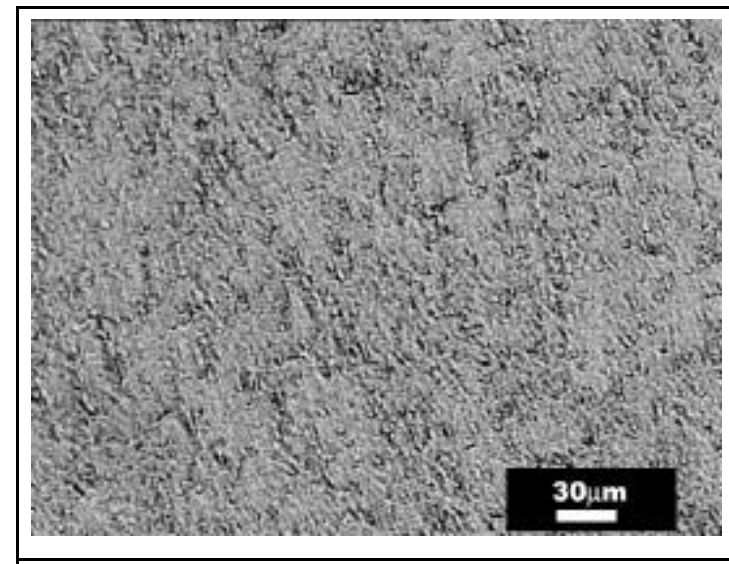

Figura 18 (g) - Al6063 - 90\%-528C - 1 min

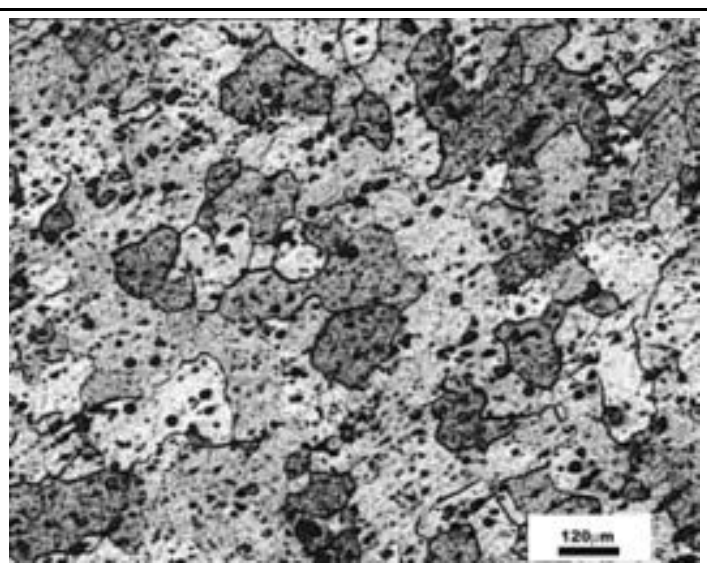

Figura 18 (h) - Al6063 - 90\%-528C-10min

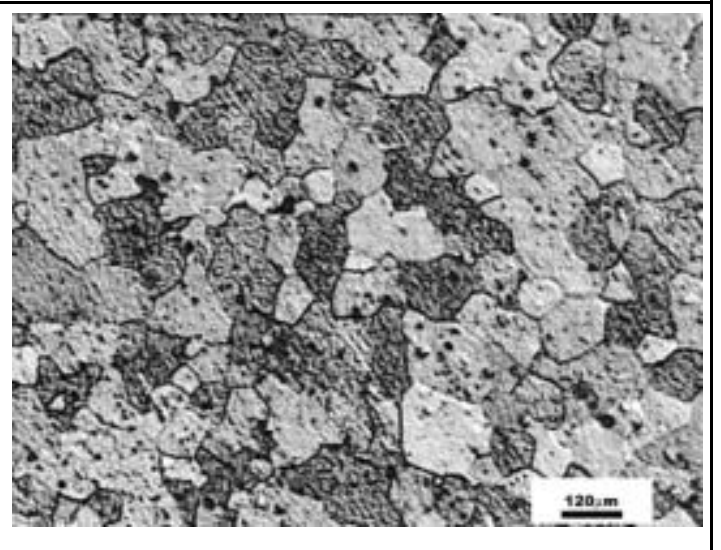

Figura 18 (i) - Al6063 - 90\%-528C-100min
Para as amostras da liga de alumínio 6063, com 90\% de redução em área e tratamentos témic os a 528으, as observações realizadas nas seqüências anteriores, com tratamentos térmicos de $396 \% \mathrm{C}$ e $462^{\circ} \mathrm{C}$, podem comparar as tendências que indicam as figuras:

Figura 18 (g): Grãos alongados, que se justifica pelo estado laminado da amostra da liga de alumínio 6063, com o tempo de tratamento em 1 minuto.

Figura $18(\mathrm{~h})$ : apresenta uma quantidade significativa de grãos equiaxiais, o que caracteriza o processo de recristalização da a mostra em estudo.

Figura 18 (i): com o aumento da temperatura observa-se grãos equiaxia is e precipitado $\mathrm{Mg}_{2} \mathrm{Si}$, 
presente na amostra da liga de alumínio 6063.

\section{4 - MIC ROSCOPIA EEIRÔNICA DE TRANSMISSÃO}

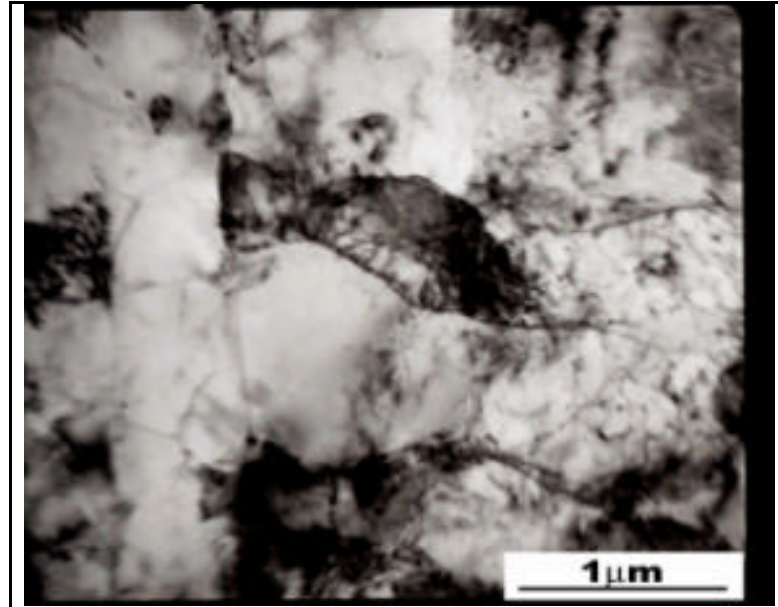

Figura 19. Al6063 - $20 \%$ de deformação plástica.

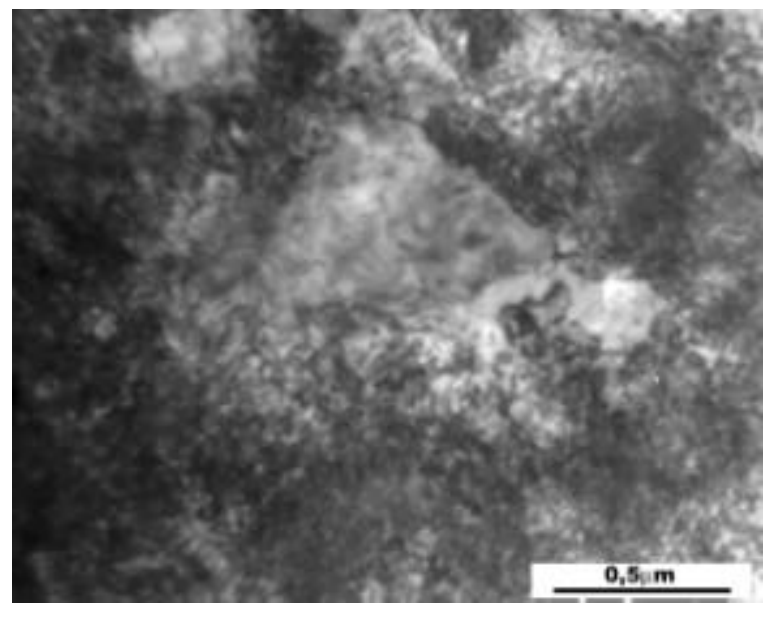

Figura 20. Al6063 -50\% de deformação plástica.

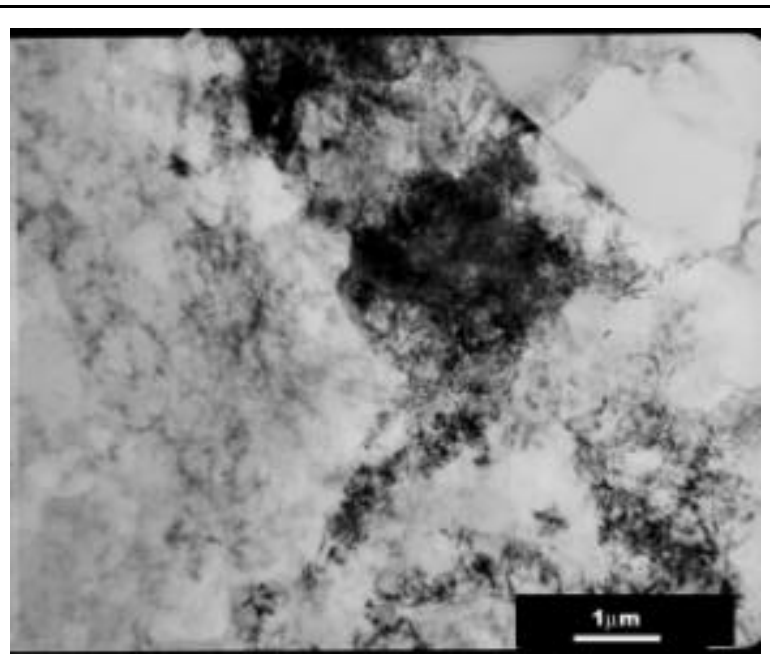

Figura 20. Al6063-70\% de deformação plástica.

$\mathrm{Na}$ análise por microscopia eletrônica de transmissão da liga de alumínio 6063, com deformação plástica de 20\%, 50\% e $70 \%$, sem tratamento témico, Figuras 19, 20 e 21, respectivamente.

Observa-se alto grau de defeitos, emaranhados de discordâncias.

Quanto maior o grau de deformação plástica observa-se, 
ta mbém, o a umento signific a tivo dosdefeitos.

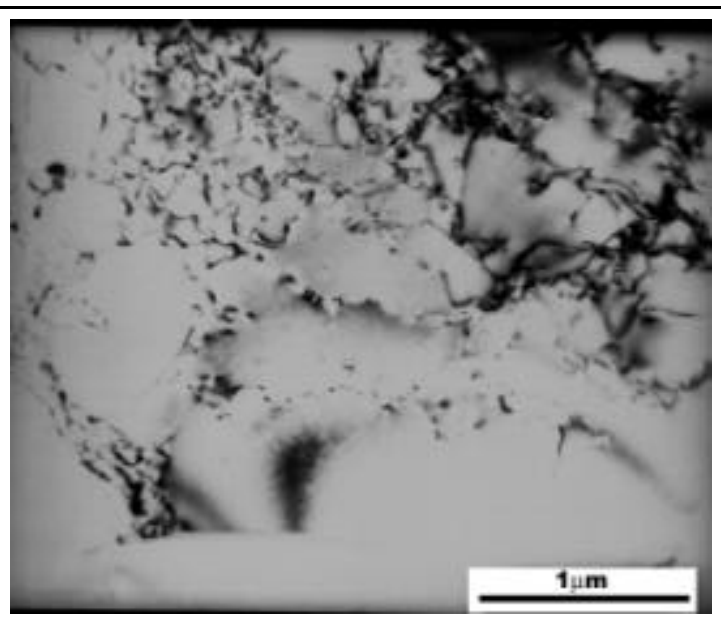

Figura 23. Al 6063 - 90\% deformação plástica - T.T. 3960 100min.

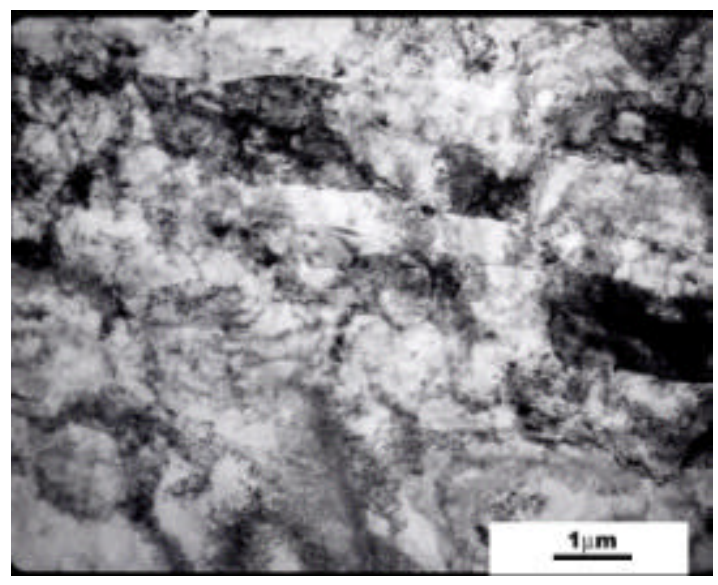

Figura 24. Al 6063 - 90\% deformação plástica, - T.T. $46201 \mathrm{~min}$.

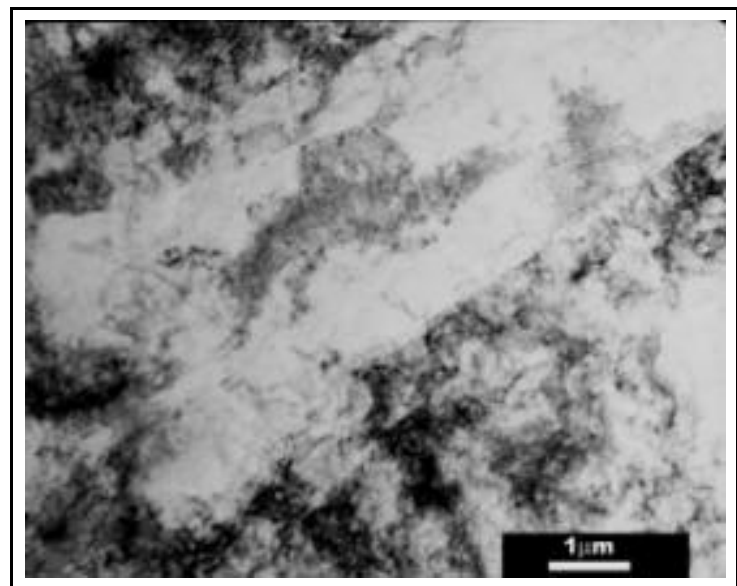

Figura 22. Al 6063 - 90\% deformação plástica - Sem trata mento Térmico.
$\mathrm{Na}$ análise por mic roscopia eletrônica de transmissão da liga de alumínio 6063, com deformação plástica de $90 \%$.

A figura 22 mostra 0 emaranhado de discordâncias, e sugere o contomo de grão, devido a imensa deformação plástica sofrida pela amostra. 
A figura 23 nos mostra, também a quantidade enome de discordâncias emaranhadas na amostra, pode-se perceber que existe contomo de grão.

A figura 24 a micrografia geral da amostra da liga de alumínio 6063 , com tratamento térmico de $462^{\circ} \mathrm{C}$ e no tempo de 1 minuto.

Algumas regiões a presentam diferentes orientações crista lográficas, evidenciadas pela diferença de contraste destas regiões.

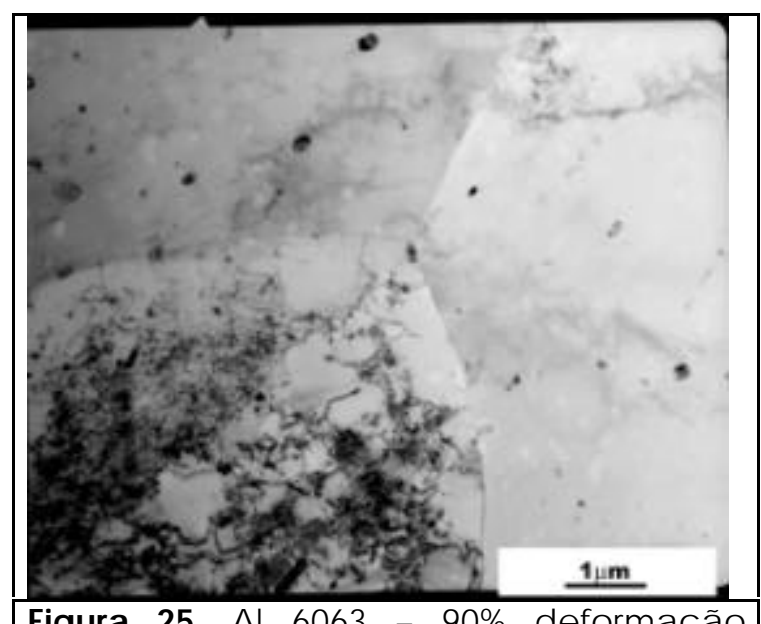

Figura 25. Al 6063 - 90\% deformação plástica, - T.T. 462일.

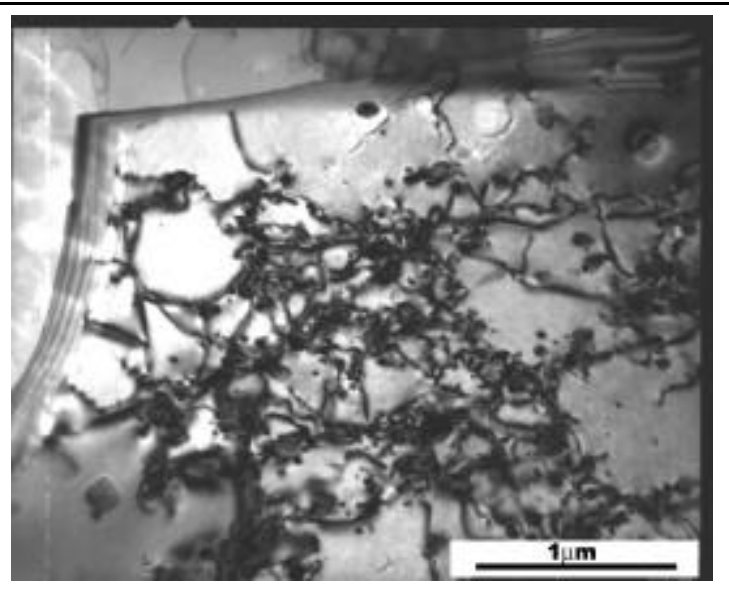

Figura 26. Al 6063 - 90\% deformação plástica, - T.T. 462일 
A figura 25, numa

micrografia de menor aumento evidenciando que em alguns grãos há poucos defeitos cristalográficos em relação a um grão com precipitados de $\mathrm{Mg}_{2} \mathrm{Si}$ em seu interior, e com distribuição parcia Imente uniforme.

Observamos na figura 26 um detalhe da figura 25 formando contomo de grão.

\section{5 - Tamanho Médio de grãos}

Na Tabela 8, estão relacionados os valores obtidos para os tamanhos de grãos da amostra da liga de alumínio 6063, com deformação plástica de $20 \%, 50 \%, 70 \%$ e $90 \%$, e tratamentos témic os em $396 \circ \mathrm{C}, 462^{\circ} \mathrm{C}$ e $528^{\circ} \mathrm{C}$, com tempos de 1 minuto, 10 minutose 100 minutos.

\begin{tabular}{|c|c|c|c|}
\hline \multicolumn{4}{|c|}{$20 \%$ de redução em área } \\
\hline Tempo & $3969 \mathrm{C}$ & $462{ }^{\circ} \mathrm{C}$ & $5289 \mathrm{C}$ \\
\hline $1 \mathrm{~min}$ & $84,2+5,5 \mu \mathrm{m}$ & $56,8+6,8 \mu \mathrm{m}$ & $37,3 \pm 4,0 \mu \mathrm{m}$ \\
\hline $10 \min$ & $108,8 \pm 5,0 \mu \mathrm{m}$ & $58,2+5,0 u m$ & $59,3 \pm 4,0 \mu \mathrm{m}$ \\
\hline 100min & $115,0 \pm 12,5 \mu \mathrm{m}$ & $84,0 \pm 5,3 u m$ & $63,2+4,0 u m$ \\
\hline \multicolumn{4}{|c|}{$50 \%$ de redução em área } \\
\hline Tempo & $3960^{\circ} \mathrm{C}$ & $462^{\circ} \mathrm{C}$ & $528^{\circ} \mathrm{C}$ \\
\hline $1 \min$ & $87,0 \pm 4,0 \mu \mathrm{m}$ & $77,1+4,8 \mu \mathrm{m}$ & $70,5 \pm 4,0 \mu \mathrm{m}$ \\
\hline $10 \min$ & $77,2+7,2 \mu \mathrm{m}$ & $77,7 \pm 4,8 \mu \mathrm{m}$ & $105,3 \pm 5,0 \mu \mathrm{m}$ \\
\hline 100min & $103,8 \pm 5,6 \mu \mathrm{m}$ & $99,0 \pm 5,0 u m$ & $106,4 \pm 6,0 \mu \mathrm{m}$ \\
\hline \multicolumn{4}{|c|}{$70 \%$ de redução em área } \\
\hline Tempo & 396ㄷ C & $462^{\circ} \mathrm{C}$ & $5289 \mathrm{C}$ \\
\hline $1 \min$ & $72,0 \pm 5,8 u m$ & $87,6+4,5 \mu \mathrm{m}$ & $66,0 \pm 3,0 u m ~ m$ \\
\hline $10 \mathrm{~min}$ & $130,5 \pm 10,0 \mu \mathrm{m}$ & $92,7 \pm 5,4 \mu \mathrm{m}$ & $71,7 \pm 4,5 \mu \mathrm{m}$ \\
\hline 100min & $133,5 \pm 7,0 \mu \mathrm{m}$ & $140,4 \pm 10,3 \mu \mathrm{m}$ & $109,0 \pm 6,8 \mu$ \\
\hline \multicolumn{4}{|c|}{ 90\% de redução em área } \\
\hline $\begin{array}{l}\text { R4Temp } \\
\text { o }\end{array}$ & $3969 \mathrm{C}$ & $4629 C$ & \\
\hline
\end{tabular}




\begin{tabular}{|l|r|r|r|}
\hline $1 \mathrm{~min}$ & - & - & \multicolumn{1}{|c|}{-} \\
\hline $10 \mathrm{~min}$ & $102,0 \pm 5,6 \mu \mathrm{m}$ & $140,1 \pm 14,3 \mu \mathrm{m}$ & $80,8+8,0 \mu \mathrm{m}$ \\
\hline $100 \mathrm{~min}$ & $137,5 \pm 12,0 \mu \mathrm{m}$ & $153,6 \pm 7,0 \mu \mathrm{m}$ & $151,8 \pm 7,4 \mu \mathrm{m}$ \\
\hline
\end{tabular}

Tabela 8. Tamanho médio de grãos.

Para ilustrar o tamanho médio de grãos da amostra da liga de alumínio 6063, como desc rito a cima, utiliza remos as figuras a seguir:
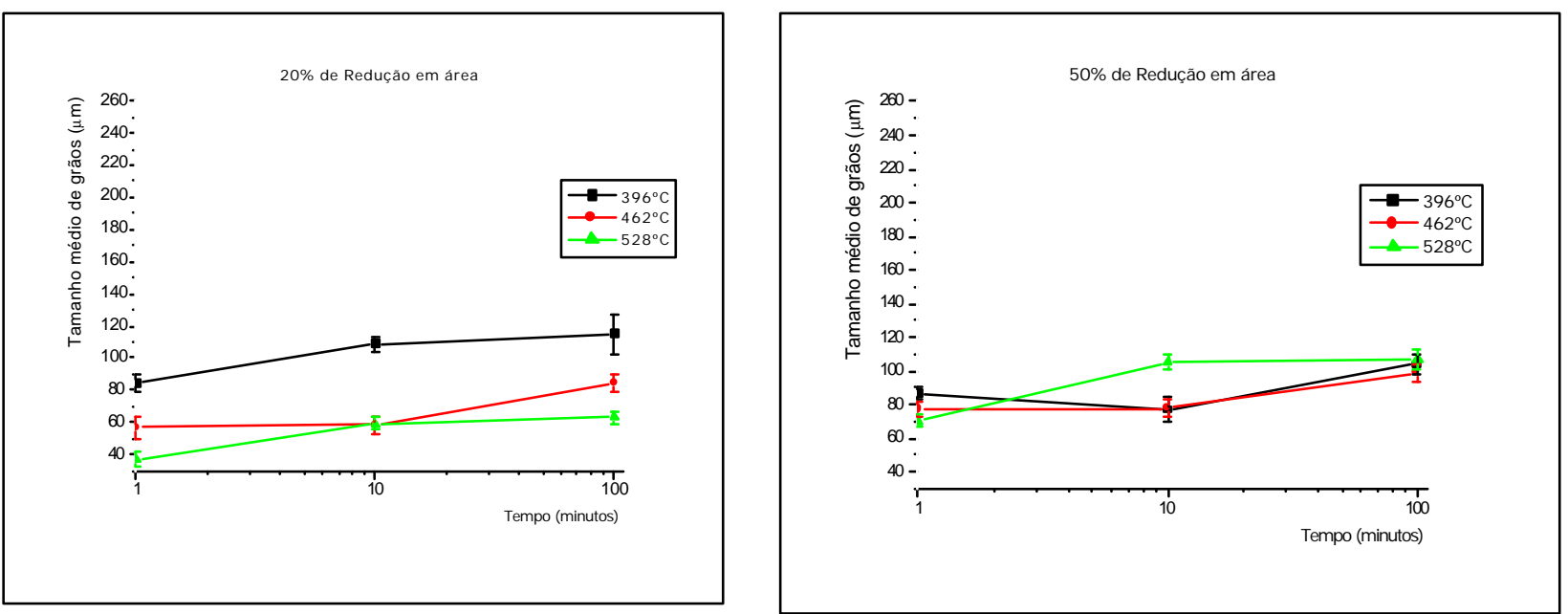

Figura 27. Al 6063 - 20\% de deformação

Figura 29. Al 6063 - 70\% de deformação plástica plástica

Figura 30. Al 6063 - 90\% de deformação

Figura 28. Al 6063 - 50\% de plástica deformação plástica
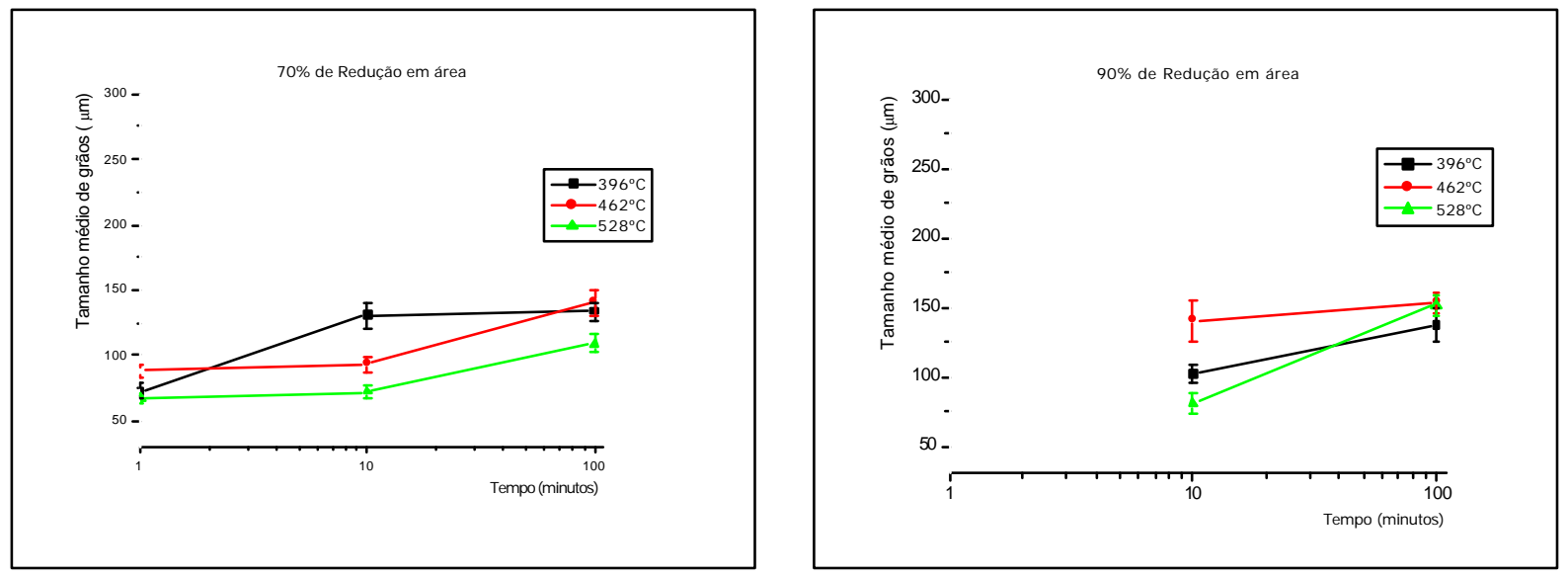

As figuras 27, 28, 29 e 30 mostram os gráficos da evolução dos grãos, com o aumento da temperatura de tratamentos térmicos pelo tempo de tratamento. 
Na figura 27, a amostra da liga de alumínio 6063 com 20\% de deformação plástica, observa-se que para a temperatura de tratamento com 396드, houve grande crescimento dos grãos da a mostra, indicando que o processo de recuperação está finalizado, o processo de recrista lização e praticamente simultâneo ao processo de crescimento de grãos, com 100 minutos de tratamento há pequeno aumento destes grãos, indicando a presença de precipitados na amostra da liga de alumínio 6063.

Quanto a temperatura de $462^{\circ} \mathrm{C}$, observa-se o crescimento contínuo de grãos, indicando, recuperação, recristalização e o crescimento de grãos propriamente dito. O que também ocorre para temperatura de 528 으, houve crescimento de grão para tempo em tomo de 100 minutos, evidenciando, também a presença de precipitados na a mostra da liga de alumínio 6063.

Na figura 28, a amostra da liga de alumínio 6063 com 50\% de deformação plástica, tem-se o mesmo comportamento das curvas de diferentes temperaturas, que observado na figura 27 , ou seja, para a temperatura de tratamento térmico de 396 o C e tempo de tratamento de 10 minutos houve um aumento do tamanho médio de grãos, decaindo signific ativamente para o tempo de tratamento de 100 minutos. Para a temperatura de $462^{\circ} \mathrm{C}$, o tamanho médio dos grãos cresceu de forma pratic amente contínua, enqua nto que para $528^{\circ} \mathrm{C}$ e tempo de tratamento de 100 minutos, a ação dos precipitados $\mathrm{Mg}_{2} \mathrm{Si}$, impedem o crescimento do tamanho médio de grãos.

$\mathrm{Na}$ figura 29, a amostra da liga de alumínio 6063 com $70 \%$ de deformação plástica, o comportamento do tamanho médio dos grãos mantêm-se semelhante com as demais defomações plásticas, (20\% e $50 \%$ ). Mostrando-se para $396^{\circ} \mathrm{C}$ em 10 minutos, um aumento significativo do tamanho médio dos grãos. Para as temperaturas de $462^{\circ} \mathrm{C}$ e $528^{\circ} \mathrm{C}$, entre 10 e 100 minutos o tamanho médio dos grãos fic aram praticamente 
constantes, evidenciando que na defomação houve muita energia a mazenada na a mostra, fluindo rapidamente para a sua rec ristalização.

A figura 30, amostra da liga de alumínio 6063 com 90\% de deformação plástica, mostra que a deformação é muito intensa na amostra e, portanto, a amostra ao ser laminada já ocorre parte da recuperação e inicio da recuperação, ocasionando um processo diferente para o tamanho médio dos grãos. Neste caso, houve para temperatura de tratamento térmico de 396 oc e no tempo de 10 minutos uma diminuição significativa do tamanho médio de grãos da amostra da liga de alumínio 6063, mantendo-se praticamente constante até o final do tratamento térmico em 100 minutos. Para as temperaturas de $462^{\circ} \mathrm{C}$ e 528 oc o comportamento do tamanho médio dos grãos é bastante parecido, ou seja, para o tempo de tratamento de 10 minutos houve um ligeiro crescimento no tamanho médio dos grãos, para ao longo do tratamento haver uma estabilização de seu tamanho, evidenciando a presença de precipitados Mg2Si presentes na liga de alumínio 6063, em estudo.

\section{6- ENSAIO DE DUREZA (VICKERS)}

Nas figuras 31, 32, 33 e 34 são apresentados os gráficos da dureza Vickers da liga de alumínio 6063, com as diferentes temperaturas de tratamento témico (1minuto, 10 minutos e 100 minutos) em diferentes temperaturas (396으, $462^{\circ} \mathrm{C}$ e $528^{\circ} \mathrm{C}$ ) e graus de deformação plástica de $20 \%, 50 \%$, $70 \%$ e $90 \%$. 


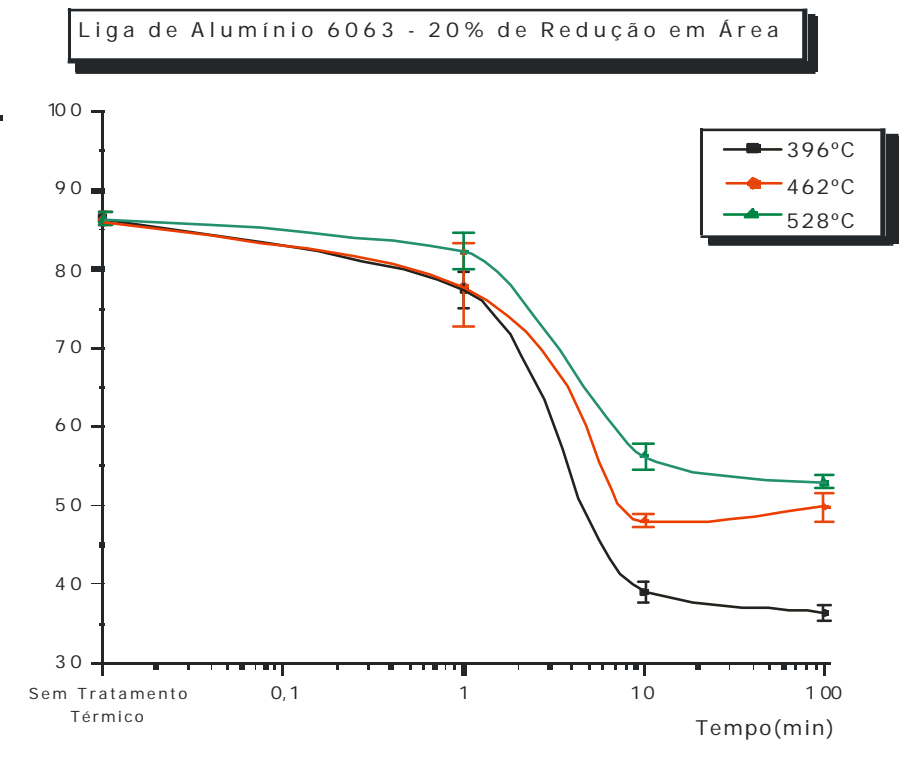

Figura 31. Mic rodureza Vickers - Al6063 $20 \%$ de deformação Plástica. Plástica.

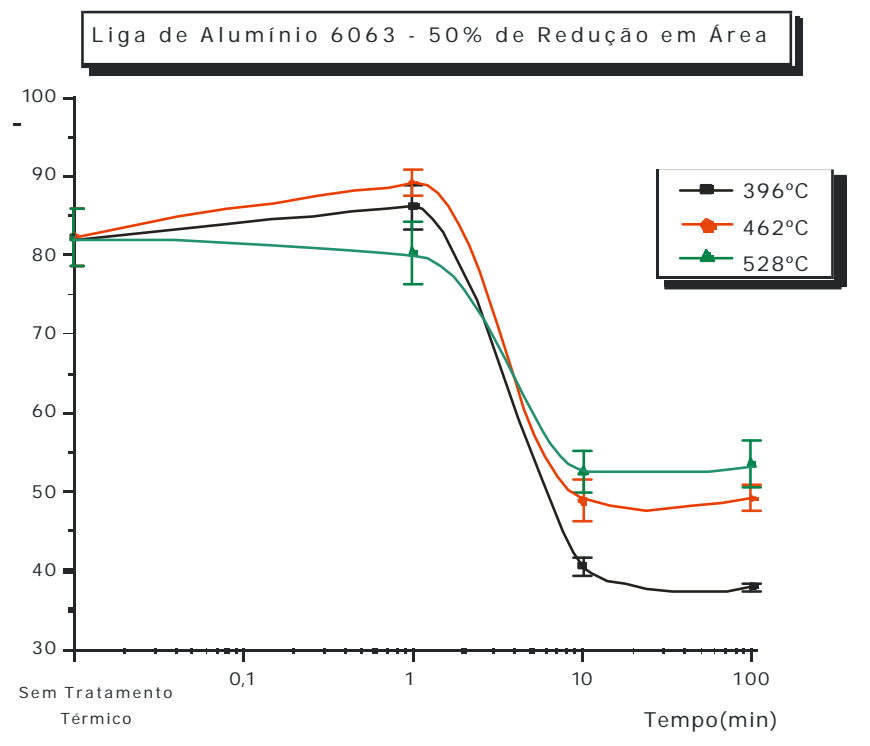

Figura 32. Mic rodureza Vickers - Al6063 $50 \%$ de deformação

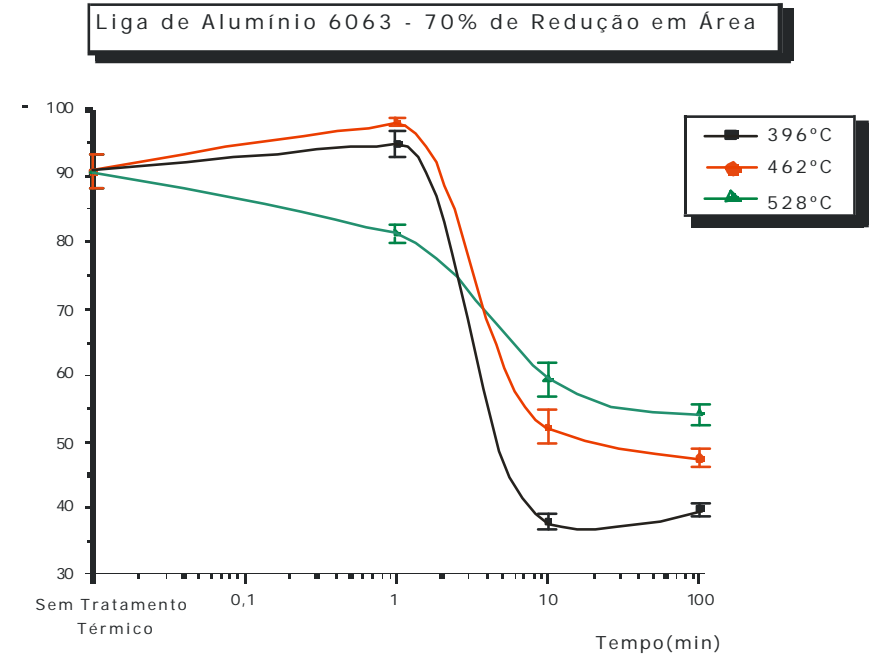

Figura 33. Microdureza Vickers - Al6063 70\% de deformação Plá stica .

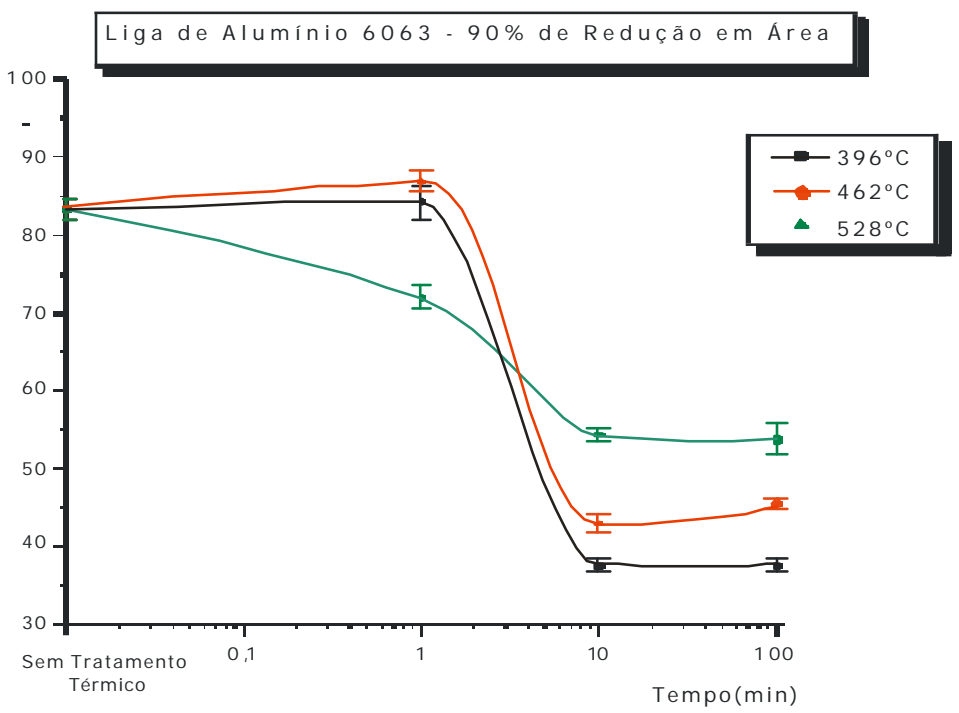

Figura 34. Microdureza Vickers - Al6063 $90 \%$ de deforma ção Plástica .

Nas figuras 31, 32, 33 e 34, correspondem as evoluções da microdureza Vickers, observadas nas amostras da liga de alumínio 6063, deformadas plasticamente em $20 \%, 50 \%, 70 \%$ e $90 \%$, com tratamentos 
térmic os com valores de $396^{\circ} \mathrm{C}, 462^{\circ} \mathrm{C}$ e $528^{\circ} \mathrm{C}$, e tempos de tratamento correspondentes a 1 minuto, 10 minutose 100 minutos.

Na figura 31, a amostra de alumínio com deformação plástica em $20 \%$ de redução em sua área inicial, observa-se a queda da microdureza inicial até os 10 minutos de tratamento témico e logo após existe uma variação entre as diferentes temperaturas. Observa-se ta mbém, que o processo de recuperação ocorre preferencia lmente até 1 minuto do tratamento térmico, após este tempo o processo de recuperação está em sua fase final, e simultaneamente ocorre a recristalização, a partir dos 10minutos de tratamento térmico a dureza aumenta evidenciando a presença de precipitados na amostra, neste caso $\mathrm{Mg}_{2} \mathrm{Si}$. Observa-se também que a temperaturas mais altas o valor obtido da microdureza Vickers, toma-se maior, portanto, para temperaturas de tratamento térmico de 528 o $\mathrm{C}$ o valor da microdureza Vickers é maior do que para o de tratamento témico de $462^{\circ} \mathrm{C}$, que por sua vezé maiorque 396 oc de tratamento témico.

Nas figuras 32 e 33, existe uma queda acentuada, paras as diferentes temperaturas de tratamento témico entre 1 minuto e 10 minutos. E nas figuras 33 e 34 a curva fica mais acentuada para as temperaturas de $396^{\circ} \mathrm{C}$ e $462^{\circ} \mathrm{C}$. Nestas figuras as curvas que representa $m$ a temperatura de tratamento témico de $528{ }^{\circ} \mathrm{C}$, toma-se mais sutil, indicando que o processo simultâneo de recuperação/recristalização ocorre a tempos de tratamentos inferiores a um minuto. 


\section{CONCUSÕES}

Baseado nas téc nicas experimenta is empregadas neste trabalho juntamente com a literatura disponível, pode-se inferir que as ligas de alumínio comercial 6063 com diferentes graus de deformação plástica ( $20 \%, 50 \%, 70 \%$ e $90 \%$ ), após convenientes tratamentos témic os (396\% C , $462^{\circ} \mathrm{C}$ e $528^{\circ} \mathrm{C}$ ) em tempos pré-estabelecidos (1minuto, 10 minutos e 100 minutos) a presentam uma seqüência de fenômenos semelhantes:

Sabendo que o processo onde a deformação plástica é sempre cresc ente, como no caso deste estudo, as regiões com predominância da mic roestrutura lamelar tendem a produção de contomos de grãos de alto ângulo dividindo em regiões distintas.

Inicialmente, o material após processos de deformação, apresenta grãos alongados, dependentes da defomação empregada, ou seja, para deformações plásticas de $20 \%$ a $70 \%$, quanto maior a deformação empregada, mais a longado o grão se a presentará.

Além disso, em deformações elevadas, da ordem de $80 \%$ a $90 \%$, as estruturas intermediárias desaparecem predominando os contomos lamelares paralelos à direção de laminação, observa-se a participação do processo de recuperação/recristalização dinâmica, caracteriza do pelo início dos sítios de nucleação formados principalmente junto aos contomos de grãos alongados (lamelares).

O alto grau de deformação, gerando uma quantidade significativa de defeitos, predominantemente discordâncias, é o responsável pela alta dureza inicial observada para a liga de alumínio comercial 6063.

Em trata mentos témicos a pós 10 minutos, os sítios de nuc leação iniciam o crescimento que serão transfomados em grãos, favorecidos 
pelo processo de recuperação e recristalização, terão seu tamanho de grão a umenta do com o transcorrer do tempo. Simultaneamente ocorre a participação de processos de precipitação que impedirá parcialmente o crescimento de tais grãos ("ancoramento de grãos"), que acontecerá provavelmente após 100 minutos de tratamento témico.

Em tratamentos com de 10 a 100 minutos, predominam os processos de recrista liza ção nas amostras. Sendo que nas em estudo temse também, ocorrência de processo de crescimento de segundas fases do tipo $\mathrm{Mg}_{2} \mathrm{Si}$, no caso da liga de alumínio 6063. 


\section{RTERÊncia Bibuográtca}

[1] ARZAMASOV, B.N. et al., Material Science, cap12. Mir Publish Moscow, MOSC OU, 1989.

[2] HALES, S.J., MCNELEY, T.R., CROOKS, R., Continuos Recrystallizatio During Thermomechanical Processing of a Superplastic Al-10Mg-0.17r alloy. Recrystalization'90 proceedings, a ustra lia, 11-16 J a 1990.

[3] SISTIAGA, J.M., Aleaciones de Alumínio y de Magnesio, cap II e III, Ed. Montecorvo, Madrid, 1963.

[4] GONÇALVES, M., Tratamento témico de ligas de alumínio: Conceitos Fundamentais, 1999.

[5] ALUMINUM STANDARDS AND DATA, The Aluminum association, Inc., 9th ed, J ulho, 1988, pag 98

[6] KO LOSOSKI, J . COUTO A.A., Curso de Metalografia do alumínio e suas ligas, ABAL, São Paulo, 1998.

[7] MONDOLFO L.F., Manganese in Aluminium alloys, Norwich. Edited by the Maganese Centre, 1977.

[8] MACHADO, R.C., Um século do processo Hall/Heroult de produção de alumínio. Metalurgia, v42.

[9] VIEIRA C.; MAZZALENIS S., A histónia do alumínio no Brasil, 30 anos ABAL, São Paulo. Ed. Antonio Belline, 2000.

[10] SIMIEW, E.A., A metalurgia física da liga de alumínio 6063, VIII Seminário de meta is não ferroso, São Paulo, 1993.

[11] GO NÇ ALVES, M., Semana da conformação ABM, SET. 1993

[12] GONÇALVES, M., Metalurgia das ligas de alumínio: Processamento, Microestrutura e propriedades, curso da ABM, São Pa ulo, Novembro 1993.

[13] PADILHA, âF., SICIUANO, F., Encruamento, Recristalização, Cresc imento de grão e Textura. ABM, São Paulo, 1995.

[14] Doherty, R.D., Recrystallization and texture. Prog. Mat Sci, 42: 39-58, 1997

[15] EMBURY, J.D. Strengthening mechanisms Al alloys - an overview of natural limits and engineering possibilities. Mate Sci Forum 217-222; 57-70, 1996.

[16] REED,R.P. e SCHRAMM, R.E. J Appl. Pys, 45: 4705, 1974 
[17] KUHLMANN - WILSDORF; D.; HANSAN, N.; Geometrically necessary, incidental and subgrains boundaries. Sc ripta Metal Materia I.

[18] ROSEN, G.I.; JENSEN, D.J . e HANSEN, N. Recovery of deformation mic roestructures in pure aluminium. Mater Sci. Forum, 113-115, 1993.

[19] HUMPHREYS, F.J. e HATHERLFY, M., Recrystallization and Related Annealing Phenomena. Esenvier Science, Oxford, 1996.

[20]HAESSNER, F. Systematic Sunvey and basic problems of recrystallization. In Rec ristallization of metallic materials. Ed. Haessner, F., 1998.

[21] VAN VLACK, LH., Princípio de Ciência dos Materiais, Ed. Edgard Bluc ker Ltda, 2002.

[22] CAШSTER, W.J r., Ciência e engenharia de Materiais: uma introdução 5 edição, LTC 2002.

[23] FURUT e NES, E., Growth rates of recrystallized grains in high by deformed commercial purity aluminium, and experimental na modelling study. Mater. Sci, Forum, 1993.

[24] VERHOEVEN, J.D. Recovery and recrystallization. In Fundamentals of physical metallurgy, J ohn Wiley \& Sons. Inc, 1975.

[25] SAKAI, T. and JONAS, J.J. Dynamic recrystallization mechanical and mic roestrutural considerations. Acta Metal, 32(2), 1984.

[26]PADIUHA, A.F. PLAUT R.L, Work hardning, recovery, recrystalization and grain growth. In TOTIEN G.E. and MAC KENZE D.S. Hand book of a lumminum, alloy production and materials manufacturing. New York. Marcel Dekker, 2003.

[27] SO UZA, S.A., Ensaios Mecânicos de materiais metálic os - Fundamentos Teónic os e Práticos - 5o ed ição - Ed. Edgard Bluc her Ltda, 1982.

[28] BUSO, S.J. - Estudos Microestruturais e por microanálise para identíicação dos precipitados presentes em amostras da liga de níquel tipo 600 após proc essos de soldagem.Disserta ção de mestrado, IPEN. 1999. 